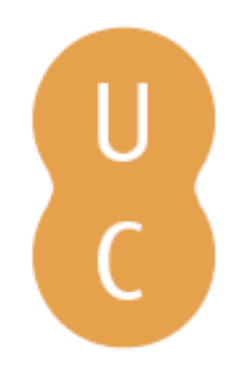

\title{
nombalina
}

\section{História concisa do Império Bizantino: das origens à queda de Constantinopla}

Autor(es): $\quad$ Monteiro, João Gouveia

Publicado por: Imprensa da Universidade de Coimbra

URL

persistente: URI:http://hdl.handle.net/10316.2/40786

DOI: $\quad$ DOI:https://doi.org/10.14195/978-989-26-1290-4_1

Accessed : $\quad$ 26-Apr-2023 16:35:11

A navegação consulta e descarregamento dos títulos inseridos nas Bibliotecas Digitais UC Digitalis, UC Pombalina e UC Impactum, pressupõem a aceitação plena e sem reservas dos Termos e Condições de Uso destas Bibliotecas Digitais, disponíveis em https://digitalis.uc.pt/pt-pt/termos.

Conforme exposto nos referidos Termos e Condições de Uso, o descarregamento de títulos de acesso restrito requer uma licença válida de autorização devendo o utilizador aceder ao(s) documento(s) a partir de um endereço de IP da instituição detentora da supramencionada licença.

Ao utilizador é apenas permitido o descarregamento para uso pessoal, pelo que o emprego do(s) título(s) descarregado(s) para outro fim, designadamente comercial, carece de autorização do respetivo autor ou editor da obra.

Na medida em que todas as obras da UC Digitalis se encontram protegidas pelo Código do Direito de Autor e Direitos Conexos e demais legislação aplicável, toda a cópia, parcial ou total, deste documento, nos casos em que é legalmente admitida, deverá conter ou fazer-se acompanhar por este aviso. 
HISTÓRIA DE ROMA ANTIGA - VOLUME 3

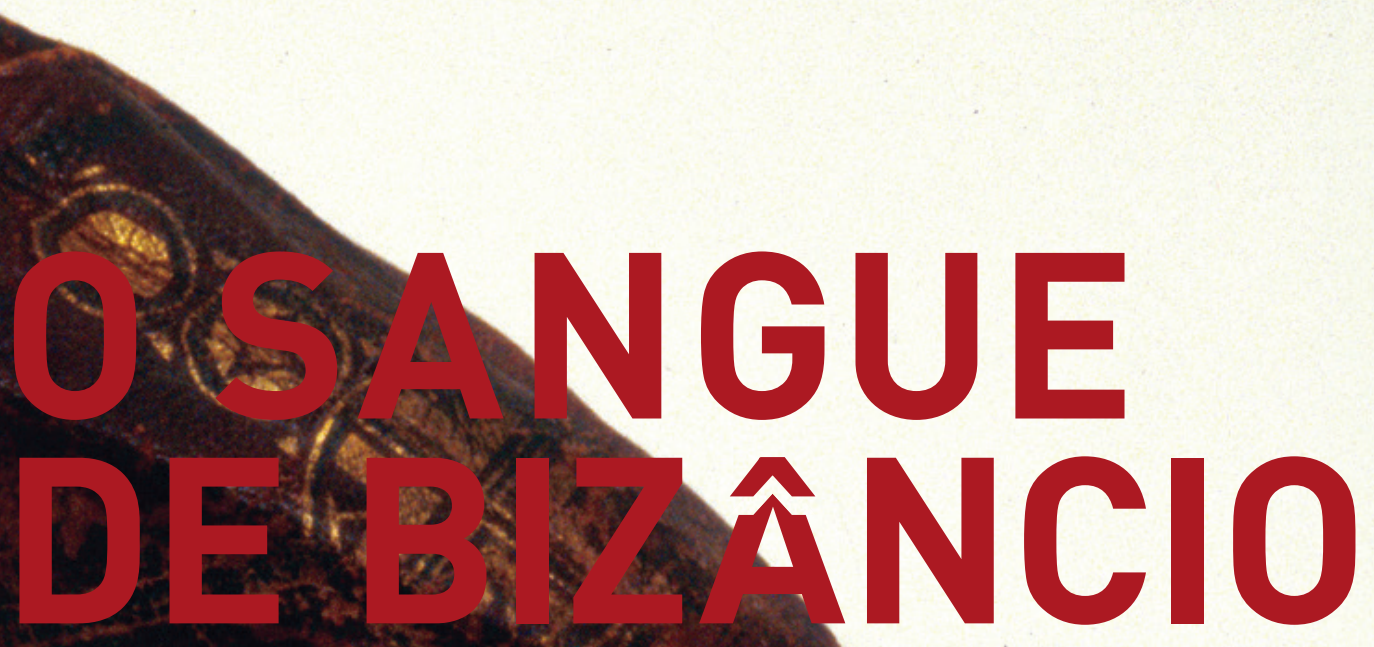

ASCENSÃO E QUEDA DO IMPÉRIO ROMANO DO ORIENTE

JOÃO GOUVEIA MONTEIRO DIR.

\section{GUSTTAVO GONÇALVES} JOÃO PAIVA DDRIGO GOMES O RAFAEL NISA 


\section{PARTE}

\section{HISTÓRIA CONCISA DO IMPÉRIO BIZANTINO \\ (DAS ORIGENS À QUEDA DE CONSTANTINOPLA)}

por João Gouveia Monteiro 
(Página deixada propositadamente em branco). 


\section{Falar de Bizâncio}

Quando, em 476, o líder dos Hérulos, Odoacro, depôs Rómulo Augústulo, o último imperador romano do Ocidente, consta que as respetivas insígnias foram enviadas para Constantinopla. Assim, de uma forma bastante simbólica, o Ocidente bárbaro reconhecia a sobrevivência mais a leste do Império Romano, num espaço político e cultural que ficou para a história com a designação de Império Bizantino. É desta imensa construção, tão pouco conhecida e injustamente mal-afamada, mas que durou até 1453, que nos cabe falar aqui. Mil anos de história - riquíssima e essencial para compreendermos a Europa em que hoje vivemos - numa casca de noz... O desafio é tremendo, mas a surpreendente originalidade do Império Romano do Oriente merece o esforço de uma tentativa séria.

Pensa-se que terá sido em meados do século vir a. C. que um grupo de famílias gregas originário de Mégara (uma cidade situada na parte norte do istmo de Corinto, a pouco mais de $40 \mathrm{~km}$ a oeste de Atenas), chefiado por um líder chamado Bizas ou Bizante, se estabeleceu na margem poente do estreito do Bósforo, dando origem a uma nova cidade, que em memória do seu chefe adotou o nome de Bizâncio. Quase mil anos depois (em 330 d. C.), o imperador Constantino I estabeleceria ali uma nova centralidade para o espaço político romano, inaugurando com pompa e circunstância a cidade de Constantinopla, que hoje todos conhecemos pelo nome de Istambul (em grego: eis tè̀n polin ou seja, "na cidade"), certamente a urbe mais conhecida e visitada da Turquia moderna. 
A posição geográfica da rebatizada Constantinopla, ligando o Ocidente e o Oriente, as suas defesas naturais (Bósforo, mar de Mármara, Corno de Ouro) e a sua privilegiada articulação com as grandes rotas comerciais terrestres e marítimas (Europa-Ásia e mar Negro-mar Egeu) justificam plenamente a escolha do primeiro imperador cristão. Constantino tratou também de acautelar a segurança da nova cidade, ao edificar uma primeira muralha que cobria uma área de cerca de 750 hectares. Devido a um crescimento populacional espetacular, que depressa conduziu ao número exorbitante de 500000 habitantes, Teodósio II (408-450) seria obrigado a ampliar a área fortificada, tanto na parte terrestre como na zona ribeirinha; quando Átila ameaçou Constantinopla, já a muralha (com doze a quinze metros de altura) se estendia por oito quilómetros junto ao mar de Mármara (ou Propôntida, como era conhecido entre os antigos Gregos), por sete quilómetros no Corno de Ouro e por seis quilómetros e meio na parte terrestre, achando-se reforçada, ao longo de todo este percurso, por 394 torres capazes de impor respeito aos mais audazes dos conquistadores (Kaplan 1991 5660). A história do Império Bizantino dificilmente se compreende se não tivermos isto presente.

Entre o fundador (Constantino) e o imperador Zenão (o homem que governava a parte oriental do Império Romano à data da deposição de Rómulo Augústulo), Constantinopla foi sede de poder para dez imperadores: Constâncio (o filho de Constantino), Juliano I ("o Apóstata", que morreu na campanha da Pérsia, em 363), Joviano (um imperador efémero), Valente (o que faleceu na célebre batalha de Adrianopla, em 378), Teodósio I, Arcádio, Teodósio II, Marciano, Leão I e Leão II. De todos estes, o mais decisivo terá sido Teodósio I, uma vez que, como já se explicou em volume anterior desta obra, foi ele quem, à beira da morte (em 395), dividiu para sempre o Império Romano em duas partes: o Ocidente (que legou ao seu filho Honório) e o Oriente (que ficou com Arcádio). 
Seguiram-se tempos muito difíceis, em que os imperadores orientais acautelaram o melhor que puderam a integridade territorial do espaço sob a sua tutela, gerindo a poderosa influência militar germânica (bem representada por homens como Estilicão, Gainas ou Fravita, que desempenharam funções relevantes na máquina do poder) e tentando 'desviar' para Ocidente o perigo bárbaro. Talvez a nomeação de Alarico como magister militum da Ilíria, com comando sobre todo o exército imperial da região e como que abrindo o seu apetite para a vizinha Itália, possa ser citada como exemplo dessa política egoísta dos basileîs de Constantinopla (basileús é o nome grego que se atribuiu, a partir de certa altura, aos imperadores romanos do Oriente). No entanto, se a metade nascente do velho Império Romano resistiu à hecatombe de 476, foi também porque as montanhas dos Balcãs travaram as incursões dos povos bárbaros que atuavam mais a poente, tendo o coração de Roma como um dos seus principais objetivos, e ainda porque tais povos não dispunham de uma frota, algo pouco menos do que imprescindível para assaltar com sucesso a poderosa cidade fundada por Constantino.

Talvez só se possa então falar, com inteira propriedade, de Império Romano do Oriente (ou de Império Bizantino) a partir de 476, e o citado episódio do envio das insígnias imperiais de Rómulo Augústulo para Constantinopla parece simbolizar isso mesmo. Nesta altura, a herança romana era, evidentemente, ainda muito forte: politicamente, a estrutura do Estado assentava no absolutismo imperial e numa burocracia pesada, que devem muito à experiência do Baixo Império romano; administrativamente, vigorava ainda o modelo de que Diocleciano fora o principal inspirador, com uma estrutura de tipo piramidal encabeçada pelo governo central e que abria depois, progressivamente, para uma rede de prefeituras, de dioceses, de províncias e de cidades; do ponto de vista ideológico e religioso, o basileús de Constantinopla assumia-se como 
herdeiro de Constantino, ou seja, como um imperador cristão que governava um espaço (o imperium) entendido como um desígnio divino, eterno e universal. Sendo escolhido por Deus, ele era o comandante absoluto da justiça, da lei e do exército e, ao mesmo tempo, o protetor da Igreja; era uma pessoa "sacra" e objeto de culto, que, à maneira de Roma, governava assistido por um Senado de composição variável (em funções desde 340 e com 300 a 2000 membros) e importância especial em matéria de legislação e de indicação do sucessor no trono, e por um Consistório - uma espécie de conselho imperial restrito que incluía membros permanentes e outros nomeados pelo basileús e que juntava os mais altos oficiais civis e militares: o quaestor sacri Palatii, responsável pelas questões legais, o magister officiorum, adstrito a vários serviços da corte, o comes sacrarum largitionum e o comes rei privatae, diretores dos departamentos financeiros, e o prefeito do pretório do Oriente, para além dos chefes militares; entres estes, distinguiam-se os comandantes da guarda imperial (o comes domesticorum e, a partir do século v, o comes excubitorum) e os dois magistri militum praesentales, dos quais dependiam os exércitos móveis de passagem pela capital; por fim, o prefeito da capital (praefectus Urbi ou, em grego, éparchos) representava o Senado, do qual era o chefe, sendo ao mesmo tempo um funcionário do Estado com um papel cada vez mais relevante na garantia da ordem pública e do abastecimento de Constantinopla, assim como no controlo da respetiva vida económica (Ravegnani 2006 19).

Curiosamente, o funcionalismo bizantino não era de transmissão hereditária, embora os seus intérpretes fossem considerados nobres. A talho de foice, podemos acrescentar que, do ponto de vista social, desde o século v se definiram diversas categorias, que ainda devem muito à velha estratificação social romana: os illustres (os mais considerados, e de onde saíam os comites), os spectabiles e os clarissimi, para além de outras dignidades relevantes mas 
reservadas aos membros da família imperial (como o patricius, o nobilissimo, o curopalate ou o kaîsar). Quanto ao título de consul, sobreviveu nos primeiros séculos, podendo ser atribuído a privados e conservando-se durante algum tempo a tradição romana de darem o nome ao ano; porém, em Bizâncio, os cônsules estavam sobretudo vocacionados para a organização de espetáculos, nomeadamente na capital (Ravegnani 2006 17-22). Como veremos mais adiante, toda esta hierarquia estava sujeita a uma etiqueta rigorosíssima, que visava constituir uma réplica da perfeição do universo e que sustentava uma espécie de religião imperial. Ora, este aspeto é já uma marca específica da civilização bizantina, que aos poucos associou, a uma interpenetração muito forte do cristianismo com a tradição clássica, o fulgor da cultura grega, língua que se imporá definitivamente a partir dos séculos vi ou viI.

No fundo, estas são as premissas de Bizâncio: um império cristão e grego, dirigido por um basileús (que era, no célebre dizer de uma das 'leis novas' de Justiniano, 527-565, “depois de Deus o pai de todos"), marcado por uma organização social e administrativa muito particular e legitimado por uma sumptuosa encenação do poder. Um império que resistiu estoicamente a terríveis adversidades (invasões sucessivas, calamidades naturais, crises internas gravíssimas) durante quase mil anos, e onde não só a política e a guerra mas também a religião e as disputas teológicas e dogmáticas tiveram uma importância nuclear. Em especial, as controvérsias cristológicas resultantes, em grande medida, da dificuldade de conciliação dos quadros da filosofia antiga e da racionalidade grega com o dogma trinitário proposto pelo cristianismo.

Já se explicou, em volume anterior desta obra, como e por que razão surgiu o arianismo (do padre Arius de Alexandria, que nos inícios do século Iv pôs em causa a dupla natureza de Cristo, humana e divina, defendendo que na Santíssima Trindade só o Pai é Deus), assim como as sequelas e respostas que esta doutrina 
suscitou, quer entre os chamados nestorianos (os discípulos de Nestor, monge sírio e patriarca de Constantinopla entre 428 e 431, que insistiam nas duas naturezas de Cristo, ao ponto de mal admitirem a unidade da sua pessoa e de recusarem a figura de Maria, mãe de Cristo, como mãe de Deus), quer entre os monofisitas (doutrina que, insistindo na unidade de Cristo e valorizando sobretudo a sua natureza divina, teve grande sucesso entre os coptas do Egito e da Etiópia, os Arménios e os jacobitas da Síria). Num primeiro concílio, convocado por Constantino e realizado em Niceia em 325, os bispos admitiram a consubstancialidade das três pessoas da Trindade e fixaram o dogma, condenando o arianismo. No entanto, este foi adotado por muitos povos bárbaros (Vândalos, Visigodos, Ostrogodos, entre outros) e impôs-se durante séculos nos reinos que estes constituíram. Em Constantinopla, em 381, um segundo concílio confirmou a condenação da doutrina de Arius; mais tarde, em 431, em Éfeso, apesar do apoio do imperador Teodósio II, um novo concílio condenou o nestorianismo, que refluiu para a Pérsia, de onde alastrou ao Turquestão, à Índia e à China. Em 451, no IV Concílio Ecuménico, reunido em Calcedónia (ao tempo de Marciano, o imperador romano do Oriente), foi a vez de o monofisismo (defendido por Eutíquio, abade de Constantinopla, e apoiado por Alexandria, contra Constantinopla e Roma) ser condenado, tendo contudo irradiado no mundo bizantino e influenciado fortemente o pensamento anti-iconoclástico, com largo apoio no seio das comunidades monásticas (Cheynet 2001 22-23; Fédou 1995105 e 108).

Em Calcedónia (cidade da Ásia Menor, situada em frente de Constantinopla), no ano de 451, o IV Concílio Ecuménico, contando com a presença de muitos bispos ocidentais, adotou pois, como já se percebeu, uma fórmula afirmativa da dupla natureza de Jesus Cristo (“... sem confusão, sem mudança, sem divisão, sem separação, a diferença de natureza não sendo de modo algum suprimida pela união"), nos termos da qual Cristo era apresentado como uma 
pessoa dotada de duas naturezas inseparáveis e era declarado perfeitamente Deus e perfeitamente homem. No entanto, o nestorianismo e, sobretudo, o monofisismo (que até tinha chegado a ser bem-sucedido num conclave realizado dois anos antes, em Éfeso) subsistiram longamente no seio do Império Bizantino, constituindo durante pelo menos dois séculos, devido à sua estreita associação com o nacionalismo político (em especial nas periferias: Síria e Egito), um grave problema para os imperadores, constantemente obrigados a ajustamentos da sua política eclesiástica e a tentativas de conciliação entre as diversas correntes (Cheynet 2001 22-23).

Em matéria religiosa, convém ainda salientar a importância do monaquismo na sociedade bizantina. Curiosamente, devido ao seu fundo marcadamente ascético e anacorético (veja-se o caso da imitação dos mártires e dos Evangelhos pelos "atletas de Cristo"), o monaquismo bizantino não conheceu nada do tipo das ordens monásticas ocidentais. No entanto, os monges e o seu ideal de vida, muitas vezes plasmado em comunidades minúsculas onde imperavam o despojamento e o trabalho manual, desfrutavam de um enorme prestígio, o que potenciava a sua intervenção na vida política do império. Talvez por isso, o concílio de Calcedónia, em 451, tenha decidido igualmente conferir aos bispos e aos patriarcas (os mais importantes, para além de Roma, eram os de Constantinopla, de Alexandria, de Jerusalém e de Antioquia) o direito de controlo espiritual sobre os mosteiros da respetiva diocese... Quando, no século VIII, se manifestou no Império Bizantino o movimento do iconoclasmo (do grego "quebra de imagens"), que considerava como idólatra a adoração das imagens santas, então a força do monaquismo (que constituiu uma espécie de vanguarda da iconodulia, a corrente que defendia a continuação dos cultos tradicionais) manifestou-se com todo o seu vigor. Em 787, um concílio ecuménico reunido em Niceia condenou o iconoclasmo, mas este 
regressou mais tarde, como que num segundo fôlego, tendo a restauração da ortodoxia e a legitimidade do culto das imagens santas sido definitivamente proclamadas em Bizâncio apenas no ano de 843 , em grande parte devido à influência dos monges. É preciso termos isto presente, se quisermos compreender a história política bizantina.

Uma última nota, em jeito introdutório, tem que ver com a intensidade da vida pública em Constantinopla. A cidade abrigava centenas de milhares de pessoas e, no seu Hipódromo, situado mesmo ao lado do Grande Palácio, decorriam divertimentos públicos muito apreciados e concorridos. Entre estes (e para além das corridas pedestres, das lutas entre atletas, das exibições de animais, dos combates de feras, das caçadas, dos jogos de habilidade e dos espetáculos cénicos, entre outros), é obrigatório realçar as corridas de carros. Também aqui, a herança da Roma antiga é evidente, mas de novo a marca bizantina é inconfundível: este Hipódromo, construído à imitação do Circo Máximo de Roma, deve ter sido erguido por Septímio Severo, mas foi Constantino quem o renovou e ampliou. Teria cerca de 400 metros de comprimento por 150 de largura, podendo as suas tribunas (de madeira até ao século $\mathrm{x}$, de mármore a partir de então) acolher entre 30000 e 50000 pessoas, que ali acorriam com enorme entusiasmo, mesmo quando as distribuições gratuitas de víveres acabaram! Desenhado em forma de retângulo, com a parte norte em hemiciclo, possuía uma pista com um leito de pedra revestido de terra batida e um muro de separação decorado com estátuas, colunas e obeliscos. Podia haver 24 corridas num só dia, entre a manhã e a tarde, entremeadas por outros divertimentos. Os aurigas (cocheiros), que conduziam os carros, beneficiavam de uma consideração social relevante e estavam organizados em quatro equipas ou fações, que mais tarde se reduziram a duas: os Azuis (que acabaram por absorver os Brancos) e os Verdes (que submergiram os Vermelhos). 
Elas próprias tratavam da organização e do financiamento das corridas, mas os respetivos chefes, que se contavam entre os dignitários cortesãos de alto nível (!), também dirigiam milícias de várias centenas de homens que podiam ser empregues pela polícia urbana ou utilizadas na defesa das muralhas da capital. O próprio imperador, no início do seu mandato, assumia a preferência por uma das fações (geralmente pelos Azuis, mais tradicionalistas e ortodoxos, ao passo que os Verdes eram mais turbulentos e muitas vezes oposicionistas e favoráveis ao monofisismo). Até ao século XII, todas as grandes festividades públicas (como o aniversário do imperador ou a celebração de um triunfo) incluíam corridas de carros no Hipódromo, sendo as mais importantes as que se realizavam a 11 de maio, dia da inauguração da nova Bizâncio por Constantino, no ano 330; nesse dia, quatro quadrigas de cavalos cumpriam sete voltas à pista, ocorrendo a competição quatro vezes de manhã e outras quatro da parte da tarde. Curiosamente, o Hipódromo comunicava com o Grande Palácio, e o basileús até dispunha de um camarote a meio da tribuna oriental (o káthisma), no qual comparecia rodeado por senadores e por outros altos dignitários. Os Azuis formavam à direita e os Verdes à esquerda, e a população não alinhada em fações ocupava o resto das bancadas; ao entrar no seu camarote, o imperador saudava primeiro a 'sua' fação e só depois a outra. O papel do Hipódromo na vida política bizantina é, pois, crucial; de resto, era ali que o imperador era levantado e aclamado no momento da sua eleição e era também ali que ele dialogava com o povo da capital. Como veremos, algumas revoltas tiveram início no Hipódromo, assim como diversas execuções capitais ou cerimónias de humilhação, arrastamento e mutilação de figuras públicas; adversários religiosos e soldados desertores também podiam ser castigados neste espaço, onde reinavam as fações dos Verdes e dos Azuis (Kaplan 1991 61-62; Ravegnani 2006 150-153; Idem 2008 107). 
2. História breve do Império Bizantino (de 476 a 1453)

A história de Bizâncio é geralmente dividida em três grandes etapas:

i) a Antiguidade Tardia, que engloba a proto-história bizantina (de Constantino a Zenão), o notável principado de Justiniano (527-565) e o governo dos seus sucessores imediatos;

ii) a época médio-bizantina, situada entre a crise do século viI (incursões dos Persas, dos Árabes e dos Lombardos) e a insólita conquista de Constantinopla pela Quarta Cruzada, em 1204, incluindo portanto a dinastia macedónica (8671057), a mais brilhantes de todas, e a famosa dinastia dos Comnenos (1081-1185);

iii) a época tardia, que inclui a resistência no exílio de Niceia, a restauração de 1261 e, por fim, a prolongada decadência política que acompanha a longa dinastia dos Paleólogos, até à conquista de Constantinopla pelos Otomanos de Mehmet II, em 1453.

De uma forma muito sintética, vamos evocar os principais momentos de cada uma destas três etapas.

\subsection{A Antiguidade Tardia, de Zenão a Maurício e Focas (finais do século iv-inícios do século viI):}

Depois de depor Rómulo Augústulo, Odoacro enviou uma embaixada a Zenão (474-491) com o objetivo de obter o título de patricius e a administração da Itália. A proposta, reveladora de como Constantinopla era considerada a continuadora natural 
da Roma eterna (aliás, "Bizantinos" é uma designação moderna, pois os habitantes deste império chamavam a si próprios Romani e até entendiam a designação "Gregos" ou "Helénicos" como depreciativa, porque sugestiva de paganismo e de idolatria), foi liminarmente recusada. Pelo contrário, Zenão, bom conhecedor da estratégia de empurrar para oeste o magister militum mais difícil de controlar, tratou de incumbir Teodorico Amalo (um ostrogodo) de ir a Ravenna depor Odoacro e restaurar a soberania imperial 'romana' em Itália... Teodorico cumpriu a missão, submetendo e matando Odoacro e a sua família e séquito em 493, talvez durante um banquete (Azzara 2013 21-22), mas depois cortou a sua ligação com Constantinopla e deu início à dominação ostrogoda em Itália, onde curiosamente tentou reanimar a decadente civilização romana e onde assegurou a consolidação económica e promoveu uma forte expansão territorial. Zenão não teve condições para reagir, tanto mais que as questões religiosas dominavam a corte bizantina, após a promulgação pelo imperador (possivelmente pró-monofisita), com o apoio do patriarca da capital, Acácio, do Henotikón, um "édito de união" destinado a conciliar as doutrinas monofisita e ortodoxa; a formulação, necessariamente ambígua, não convenceu, e o papa Félix III (ou II) excomungou o patriarca, que reagiu e deu início ao chamado "cisma acaciano", que se prolongou durante três décadas (Norwich 2012 30-31).

À morte de Zenão, o Senado escolheu Anastácio I (491-518), seguindo a indicação da viúva Ariadne, que terá mesmo casado com o novo imperador, um antigo e respeitado funcionário da corte. Anastácio I fez um grande saneamento financeiro e, apesar das várias guerras em que se envolveu (revolta dos Isaurianos, invasão búlgara dos Balcãs, conflito com os Persas do rei Cavade), deixou um monumental tesouro de 320000 libras de ouro. Do ponto de vista religioso, o novo basileús defendeu a ortodoxia e a neutralidade até 511, ano em que decidiu apoiar abertamente o 
monofisismo, uma decisão que serviu de pretexto para uma revolta popular encabeçada pelo comes foederatum da Trácia, Vitaliano, e patrocinada pelo patriarca da Macedónia, esmagada a muito custo quatro anos mais tarde, depois de Anastácio ter chegado a considerar a hipótese de abdicar (Ravegnani 2008 53).

Anastácio I faleceu sem filhos e já depois da morte de Ariadne, pelo que, logo na noite de 9 para 10 de julho de 518, os senadores e o exército se reuniram (separadamente) para discutir a sucessão: no Hipódromo, o magister officiorum Celere juntou o corpo de elite dos scholae palatinae, enquanto o comes excubitorum Justino fazia o mesmo com a guarda imperial; quanto ao Senado, reuniu-se com o patriarca de Constantinopla no Grande Palácio (no pórtico diante do Triclínio dos XIX Leitos, a sala de banquetes). A demora na tomada de decisão inquietou o povo, impaciente nas escadarias do Hipódromo, de tal maneira que houve lugar a aclamações avulsas pelas fações (em especial pelos Azuis), à oferta do trono a diversas pessoas (entre as quais Justiniano, que recusou) e até a tumultos e a tentativas falhadas de coroação! Por fim, o Senado decidiu-se por Justino, que soubera fazer bom uso da sua influência junto da guarda imperial. Justino I (518-527) era um homem rude e inculto, que subira a pulso na corte bizantina, e Procópio de Cesareia, a nossa melhor fonte para esta época, deixou-nos da sua chegada a Constantinopla, nos anos 470, acompanhado pelos dois irmãos, uma sugestiva descrição nas preciosas Anékdota (ou Histórias Secretas):

"Quando o imperador Leão [I] exercia o poder supremo em Bizâncio, três jovens camponeses de estirpe ilírica - Zimarco, Ditibistos e Justino, de Bederiana [pequena povoação da Dácia mediterrânica] -, em luta contínua contra as carências domésticas, para se libertarem [delas] decidiram alistar-se no exército. Encaminharam-se para Bizâncio, trazendo às costas os sacos 
repletos apenas do pão seco que ali tinham colocado à partida. Quando chegaram, foram arrolados no exército, e o imperador destinou-os para a guarda palatina: tinham, todos eles, um físico notável" (Conca 1996 VI 2-3 100-101).

Durante as guerras de Anastácio I, Justino tivera uma ascensão vertiginosa e tornara-se, como já dissemos, chefe da guarda imperial (comes excubitorum). Na altura em que foi eleito imperador, também graças à sua ortodoxia calcedónia, já tinha mais de 65 anos de idade e era casado com uma antiga escrava, Lupicina, que, ao tornar-se imperatriz e augusta, mudou o seu nome para Eufémia. Além do tesouro acumulado por Anastácio I, o novo basileús herdou diversos problemas militares e religiosos, agravados por catástrofes e fenómenos naturais (terramotos, incêndios, inundações, auroras boreais, cometas, eclipses, pragas de gafanhotos, epidemias), que já vinham do reinado anterior e que pareciam confirmar a proximidade do fim dos tempos. Aliás, o declínio de Roma estava tradicionalmente associado à ideia de fim do mundo e, na profecia de Daniel acerca dos quatro reinos terrestres (Antigo Testamento), muitos identificavam o último desses reinos com o Império Romano. Diversas passagens dos evangelistas Mateus, Marcos e Lucas pareciam sustentar esta previsão, e as cartas de Paulo sugeriam também que o Império Romano constituía o derradeiro travão à chegada do fim do mundo. Ora, este império caíra em 476, e diversos textos, como a Teosofia de Tubinga (um texto oracular da época de Anastácio I), asseguravam que a vinda do Anticristo estava iminente; do mesmo modo, o Oráculo de Baalbek (c. 503-504) afirmava que, na altura do fim do mundo, apareceria um imperador de nome desconhecido, mas semelhante ao dia do Juízo Final (e "Anastácio", em grego, significa "ressurreição").

Assim, por volta do ano 500, a inquietação religiosa era grande; só não se sabia o momento em que ocorreria o fim do mundo e 
o retorno de Cristo, mas pensava-se que poderia estar muito próximo. Aliás, no Salmo 90, 4, encontramos a sugestão de que cada dia da criação corresponde a 1000 anos ("porque mil anos são em teus olhos como o dia de ontem, quando já passou: e como a vela da noite": Bíblia, ed. Tolentino de Mendonça, trad. de Annes d'Almeida 2006 V 65), estando por isso o mundo terreno destinado a durar 6000 anos; ora, desde o século in d. C. que se calculava o nascimento de Cristo no ano 5500, pelo que o fim do mundo deveria ocorrer 500 anos depois (recordem-se Hipólito de Roma ou Sexto Júlio Africano), ou seja, cerca do ano 500, precisamente a época de Anastácio I (Meier 2007 23-26)...

Justino I não teve portanto vida fácil, mas também não dispôs de tempo para grandes reformas, uma vez que faleceu logo em 527. Mal preparado para a função, durante o seu governo apoiara-se muito nos sobrinhos, em especial em Petrus Sabbatius, mais tarde chamado Flavius Petrus Sabbatius Iustiniano. Este sobrinho Justiniano era, também ele, natural de Bederiana (Taurisium, na atual Macedónia); nascera em 481 ou 482, sendo filho de um trácio e de uma irmã de Justino; viera ainda jovem para Constantinopla, onde, ao contrário do tio, recebera uma educação bastante sólida, à base de latim (mais do que grego), direito, retórica, história romana, teologia e arte da guerra (Cheynet 2001 26). Jovem aristocrata ambicioso e um fervoroso adepto dos Azuis no Hipódromo da capital (participou até em alguns desacatos que o levaram aos calabouços), Justiniano teve a carreira facilitada devido à sua proximidade do imperador, pelo que ascendeu de forma meteórica na corte de Constantinopla: em 518, à morte de Anastácio I, tornou-se um dos 45 oficiais da guarda dos scholae palatinae, no ano seguinte recebeu o título de comes, depois tornou-se magister equitum et peditum praesentalis (ou seja, alto general), em 521 distinguiu-se como consul (tendo organizado espetáculos sumptuosos, com vinte leões e trinta leopardos, que custaram uma fortuna) e, 
a seguir, recebeu a dignidade de patricius. Muito possivelmente, terá sido adotado pelo tio, tornando-se o seu sucessor natural. De resto, as fontes sugerem que governaram em conjunto e que Justiniano beneficiou muito disso, não só para ganhar experiência mas também para afastar possíveis concorrentes ao trono (como o eunuco e camareiro Amâncio, um pró-monofisita, ou o magister militum e cônsul Vitaliano, um apoiante das decisões do concílio de Calcedónia).

A 1 de abril de 527, Justiniano, já com 45 ou 46 anos de idade, foi associado formalmente ao trono, por indicação do tio (gravemente doente) e sob pressão do Senado. Três dias depois, seria coroado numa nova assembleia, convocada por si e que reuniu todos os grandes, incluindo o patriarca de Constantinopla. Como observa Mischa Meier, que compara esta cerimónia com a coroação de Leão II, em 474 (realizada no Hipódromo pelo avô Leão I, já muito enfermo, com forte participação popular e militar), Justiniano foi coroado no palácio e sem intervenção do povo, apenas na presença do chefe da Igreja, dos altos cortesãos, dos senadores e dos soldados; e até datou o seu reinado a partir do dia 1 de abril de 527, desvalorizando a assembleia do dia 4: "Era, portanto, apenas Deus que tinha transmitido o poder a Justiniano, através da mediação do tio Justino" (Meier 2007 11).

Justiniano foi, assim, o primeiro imperador bizantino a assumir desde o início o seu mandato divino, sem necessidade de qualquer caução popular. Como então resumiu o diácono Agapito de Constantinopla, "Deus não pressupõe nada nem ninguém, o imperador pressupõe apenas Deus" (Ekthesis 63, citado por Meier 2007 9). O projeto de Justiniano, o mais famoso imperador de toda a história bizantina, retomava a herança de Constantino I, mas numa tonalidade mais forte, afirmando claramente a legitimidade divina do imperador, a sua devoção integral e o seu espírito de missão. No prefácio dos Digesta (logo em 530), Justiniano afirma 
governar em nome de Deus e buscar, através de guerras bem-sucedidas, a paz, a ordem e a estabilidade, sabendo à partida que tudo depende do favor da Santíssima Trindade. Para ele, tudo era uma dádiva de Deus: os sucessos constituíam uma recompensa, e os fracassos eram um castigo. No fundo, Justiniano retomava o célebre modelo de Eusébio de Cesareia, que em 335, na festa dos trinta anos de reinado de Constantino, afirmara que o império terreno configurava uma imitação do império celeste, existindo um só Deus e um só imperador, vigário de Deus na terra, sábio, devoto, justo, corajoso, vencedor e rei dos filósofos... Em síntese, conjugando a tradição secular com os valores próprios do cristianismo, postulava-se que o poder do imperador cristão era uma imitatio Dei, uma mímēsis theoú (Meier 2007 8). Deste modo, Eusébio colocava na sombra o outro fundamento do poder imperial da República romana, nunca formalmente abolido: a soberania do populus romanus; com Justiniano não haveria, portanto, ensejo para a insurreição popular...

O reinado de Justiniano (que governou durante quase quarenta anos!) foi também um tempo de transformação da iconografia imperial, com um claro impulso dado às temáticas cristãs (nas moedas de ouro, os solidi, a tradicional representação da Victoria surge reinterpretada sob a forma de anjos), o que explica igualmente a generalização do globo e da cruz, símbolos do domínio universal sob o manto do cristianismo. Homem de fortes convicções ortodoxas, e como tal apoiante das decisões do IV Concílio Ecuménico de Calcedónia - 451 (nomeadamente do dogma das duas naturezas mas uma única vontade divina: a chamada fórmula diofisita ou calcedónia), Justiniano não deixou porém de buscar o diálogo com os moderados, promovendo colóquios com monofisitas como o patriarca de Antioquia, Severo, que lhe valeram dissabores com Roma e que acabaram por redundar no Sínodo de Constantinopla de 539, em que, com o apoio do próprio imperador, Severo foi 
condenado e a autoridade dos quatro primeiros concílios ecuménicos foi reafirmada. O risco da rutura com a Igreja de Roma e a vontade de Justiniano, amante da teologia e crente, de elevar as suas opiniões religiosas a dogma universal, explicam esta evolução, assim como o desejo imperial de restaurar o cristianismo calcedoniano no Egito, mesmo à custa da deposição do patriarca de Alexandria, Teodósio; no Codex Iustinianus, afirma-se o objetivo de impor uma unidade religiosa em todo o Império Romano, de acordo com uma fé comum ditada pelo imperador: a fé trinitária aprovada em Calcedónia (Meier, 2007 31-35).

No contexto em que assumiu o poder, com a contradição crescente entre as expectativas do fim do mundo e a não ocorrência do regresso de Cristo (o que punha em causa a escatologia cristã e o sistema tradicional de datação do mundo), Justiniano sentiu-se na necessidade de dar muitas explicações às angústias populares e gastou muita energia no esforço de criar uma imagem de uma nova época, em que ele próprio surgia iluminado por Deus em tudo e em todos os momentos. No entanto, a sua política religiosa - como já percebemos - não esteve isenta de contradições e ziguezagues. Curiosamente, o próprio casal imperial parece espelhar alguma dessa incoerência, pois Teodora era uma monofisita convicta e parece ter atuado com bastante autonomia, protegendo muitos monofisitas no palácio de Ormisda e mantendo-os até em contacto com o basileús! É sabido, por exemplo, que Teodora apoiou Jaime Baradeu, o bispo que fundou a igreja independente (jacobita) da Síria, e também terá fornecido eclesiásticos monofisitas ao árabe Al Harith, os quais converteram a Núbia. Mas claro que Justiniano permitiu tudo isto, e o sinal de uma terrível fratura religiosa no seio do casal imperial também pode ser visto como o sinal de uma estratégia deliberada do astuto e experiente basileús, que, tudo o indica, terá amado profundamente Teodora, que faleceria em 548; Justiniano parece ter-se-lhe mantido fiel e é sabido que visitou 
regularmente o seu túmulo, na Igreja dos Santíssimos Apóstolos, em Constantinopla.

Não é possível falar de Justiniano sem lembrar a extraordinária figura desta imperatriz Teodora, que tanta atração e repulsa tem suscitado, sobretudo depois da redescoberta, no século xviI, das Anékdota de Procópio (um fervoroso opositor do mais ilustre casal imperial bizantino). Teodora era filha de um domador de ursos, que trabalhava para os Verdes e que morreu ainda novo. A sua mãe voltou a casar e passou-se para a fação dos Azuis; tanto ela como as filhas atuavam como 'atrizes', profissão de baixa reputação social e que implicava participar (com pouca roupa vestida) em espetáculos cénicos e récitas populares. Procópio diz mesmo que Teodora vendia o seu corpo e fala em filhos e em abortos, pensando-se que ela se tornou amante do governador Ecébolo, que acompanhou no norte de África até por ele ser repudiada. De volta à capital, Justiniano, que amava o ambiente do Hipódromo, tornou-se seu amante, mas a tia Eufémia impediu o casamento (com base numa lei do imperador Otávio Augusto); à morte da sua tia, Justiniano alterou a lei e casou com Teodora, que se tornaria imperatriz: não deve ter sido nada fácil para os senadores, então compelidos a prestar homenagem à antiga artista, de joelhos, no Grande Palácio... As imperatrizes não costumavam ter grande interferência na política bizantina, mas é possível que Teodora tenha influenciado algumas das decisões do marido, designadamente sobre as atrizes, sobre a condição da mulher (lenocínio, prostituição) ou sobre o financiamento de instituições de caridade como o mosteiro de Metánoia (arrependimento); no entanto, como lembra Meier, Teodora, embora surja em alguns documentos ao lado do imperador, não figura na maior arma de propaganda do tempo: as moedas (Meier 2007 53; e Cesaretti 2003 passim).

Geralmente, atribui-se a Teodora um papel vital num dos mais graves acontecimentos do reinado de Justiniano: a revolta Níka (ou 
Níkē, que significa Vitória!), ocorrida em Constantinopla, em 532. Num ambiente de fortes tensões sociais e religiosas, exacerbado por um crescimento demográfico explosivo, por grandes dificuldades económicas e pelo aumento da pressão fiscal, o povo da capital, a partir das fações do Hipódromo, revoltou-se violentamente e durante dez dias provocou saques e incêndios terríveis na cidade (daí resultou, por exemplo, a semidestruição da Igreja de Santa Sofia). A gota de água parece ter sido a condenação à morte, pelo prefeito da capital (Eudémono), de sete rebeldes do circo, assim como a recusa do imperador, em pleno Hipódromo, de conceder clemência a dois dos condenados que, fortuitamente, não tinha sido possível crucificar. Durante a revolta que se seguiu, a população amotinada exigiu a demissão de Eudémono e também a do prefeito do pretório do Oriente, João da Capadócia, e ainda a de Triboniano, um dos colaboradores mais próximos de Justiniano: o imperador acedeu, parecendo mostrar uma fraqueza que os senadores da oposição aproveitaram para começar a fazer planos para o futuro. O mais carismático general de Justiniano, Belisário, foi para as ruas combater os revoltosos, o que ainda incendiou mais os ânimos; neste ambiente, o povo aclamou um dos sobrinhos de Anastácio I, chamado Hipázio, ao mesmo tempo que corria o rumor de que o basileús legítimo preparava a fuga, que Teodora terá travado à última hora - repetindo o antigo dito "o poder é um esplêndido sudário" e exortando o marido a reagir e a lutar pelo trono... Há, no entanto, quem defenda que tudo isto não passou de uma encenação, de uma manobra maquiavélica de Justiniano, que assim obrigou a oposição a desmascarar-se e conseguiu reunir os revoltosos no Hipódromo, onde o general Narsés, depois de comprar a fação dos Azuis, semeou a discórdia, abrindo caminho para os generais Belisário e Mundo trucidarem a multidão. No final, havia 30000 a 35000 mil mortos, e muitos senadores foram exilados e viram os seus bens confiscados; quanto a Hipázio, seria justiçado 
como usurpador, juntamente com o seu irmão Pompeio. Desejada ou não por Justiniano, a Níka, a mais grave revolta popular da história do Império Bizantino, serviu para uma grande demonstração de força do imperador, que a partir daí, graças ao 'efeito de terror' que o acontecimento (largamente divulgado) produziu, não mais esteve verdadeiramente em perigo, nem foi contestado pela classe senatorial durante muito tempo. É certo que a popularidade do basileús caiu a pique, mas a sua autoridade saiu extremamente reforçada (Meier 2007 43-49; Kaplan 1991 61; Ravegnani 2006 44).

É hábito associar o principado de Justiniano a três grandes feitos: i) a reconquista de uma parte significativa do desaparecido Império Romano do Ocidente; ii) uma reforma profunda do Direito; iii) a edificação de grandes obras públicas.

Em relação à reconquista territorial, este foi assunto tratado no volume anterior desta obra e não iremos repetir-nos. Basta lembrar que tudo parece ter começado em 533 (o ano a seguir à Níka), com a intervenção de Belisário no norte de África, onde o imperador desejava vingar a deposição do rei dos Vândalos, Hilderico (seu amigo e simpatizante do catolicismo) pelo rival Gelimero. Tendo corrido bem e conduzido à criação da prefeitura do pretório de África (em 534) e ao reordenamento da respetiva Igreja (em 535), Justiniano terá começado a conceber um verdadeiro programa de restauração, que teve como grande alvo a Península Itálica. Isso conduziu à I Guerra Gótica (a partir de 535), onde, depois de muitos avanços e recuos e ao fim de cerca de quatro anos, Belisário e Narsés conseguiram vencer os descendentes de Teodorico (Teodato e Vitige, muito em especial). Anos mais tarde (entre 541/42 e 552), a Guerra Gótica conheceria uma segunda fase, com o rei Totila a poder contar com a cumplicidade dos Francos, valendo a Bizâncio a grande capacidade do general Narsés (um camareiro e eunuco pró-monofisita, que era o favorito de Teodora e um homem muito 
rico), o qual obteve vitórias decisivas em Busta Gallorum (em 552, onde Totila encontrou a morte) e na batalha de Mons Lactarius (Salerno), no mesmo ano. Este sucesso significou a reentrada da Itália no Imperium Romanum e permitiu a Justiniano, em 554, a reorganização da região, com a promulgação da Constitutio Pragmatica. Na Hispânia, Justiniano interveio a partir de 552, a pedido do rei visigodo Atanagildo, em revolta contra o rival Agildo; os Bizantinos aproveitaram para se apoderar de Cartagena, de Málaga e de Córdova, assim como do respetivo hinterland, um domínio que todavia não conseguiriam manter por muito tempo.

Contudo, para além de tudo isto, Justiniano teve também de travar uma dura guerra contra os Persas, com quem assinara uma suposta "paz eterna" em 532, depois dos ataques do rei Cavade e de Cosroés I na Ibéria do Cáucaso e na Arménia. O soberano parece ter adormecido à sombra desta "paz eterna", que lhe permitiu ter as mãos livres para intervir em África e na Itália. Os Persas agradeceram a desatenção e o rei Cosroés I tomou Antioquia e atacou a Lazica (a leste do mar Negro) em 540, conquistando Petra (um bom ponto estratégico, na atual Jordânia) no ano seguinte e reacendendo assim uma guerra que se prolongou, dura e crua, por vários anos, com intervenção, sobretudo, do general Sitas (o primeiro magister militum per Armeniam) e de Belisário; o conflito acabaria por conduzir à assinatura de um armistício (em 545, renovado em 551 por mais cinco anos, com os Bizantinos a pagarem 2000 libras de ouro de cada vez) e, por fim, à paz de 561, em que Bizâncio ficou obrigada a versar um tributo anual de 30000 moedas de ouro aos seus mais temíveis rivais. Finalmente, há que referir as dificuldades sentidas por Justiniano nos Balcãs (região cuja defesa descurou demasiado), que permitiram desordens regulares na Trácia, na Ilíria e na Grécia, com ataques dos Eslavos, dos Germanos, dos Búlgaros e dos Hunos e, em 559, uma grande investida dos Búlgaros Cutrigui, que chegaram a ameaçar 
Constantinopla! O imperador recorreu de novo a Belisário (que chegara a afastar e a manter sob vigilância apertada, por suspeita de ambição ao trono), e o velho general acabou por triunfar outra vez. O soberano tentou comprar a paz aos Búlgaros e aos Eslavos, por meio de tributos, e recorreu à estratégia (bem bizantina) de os lançar uns contra os outros, ao mesmo tempo que reforçava as fortalezas raianas, mas a verdade é que sentiu sempre imensas dificuldades nesta geografia setentrional.

No que diz respeito à obra jurídica de Justiniano, ela ocorreu logo na primeira fase do seu reinado, entre 528 e 542, e materializou-se sobretudo na produção do famoso Corpus Iuris Civilis, destinado a pôr cobro à confusão legislativa reinante e a melhorar e atualizar o Codex Theodosianus (elaborado no tempo de Teodósio II). O Corpus compõe-se de três partes: o Codex Iustinianus (uma recolha e adaptação das leis imperiais desde o século II até 534); as Institutiones (um manual jurídico para estudantes); e os Digesta ou Pandeta (uma recolha de jurisprudência romana (especialmente dos séculos II e III, reunindo Ulpiano e outros 40 juristas) para uso nos tribunais (incluía cerca de 2000 casos). O tiro de partida para esta reforma foi dado em 13 de fevereiro de 528, por uma comissão de dez pessoas, com a tarefa de recolher as leis imperiais ainda válidas, reordená-las e, se necessário, interpolá-las. Em abril de 529, já o Codex estava a ser publicado, anulando as recolhas anteriores, tendo os 50 livros dos Digesta, preparados por uma comissão de dezassete pessoas chefiada por Triboniano, entrado em vigor, com força de lei, em 533; por volta do mesmo ano entraram também em vigor as Institutiones e procedeu-se a uma reforma do ensino do Direito. No ano seguinte surgiu uma edição revista do Codex (com leis a partir do imperador Adriano), que felizmente se conservou até hoje (ao contrário da edição original), e assim se encerrava o chamado Corpus Iuris Civilis, uma designação atribuída apenas no século XVI. No entanto, até 542 surgiriam ainda 
150 novas leis (as Novelle, neste caso em língua grega, um sinal claro do rumo cultural que o Império Bizantino estava a tomar), que acabaram por nunca ser sujeitas a uma recolha independente. Em toda esta profunda reforma jurídica, ainda hoje objeto de estudo nas nossas universidades, o imperador surge como lex animata, ou seja, como uma entidade capaz de legislar, nos termos de um poder que lhe vem de Deus. A figura principal deste processo foi Triboniano, um homem natural da Panfília (na Ásia Menor), que estudara Direito romano em Berito ou em Constantinopla e que era (tal como o seu imperador) um grande conhecedor da história romana; Triboniano optou por trabalhar com jovens competentes (em vez da antiga elite de funcionários jurídicos) e seria nomeado quaestor sacrii palatii desde 529 até à sua morte (em 542), com exceção do curto período em que grassou a revolta Níka. Também ele não colheu a simpatia de Procópio de Cesareia, que o considerava um corrupto e um cínico, para além de ter fama de pagão ou de ateu (Ravegnani 2006 45; Meier 2007 38-40).

Quanto à política de obras públicas de Justiniano, salientam-se as vastas obras defensivas realizadas em cidades fortificadas e castelos, especialmente em África, e alguns monumentos notáveis, de entre os quais é obrigatório realçar a reconstrução da Igreja de Santa Sofia, a partir de 537, expressão máxima do talento dos famosos arquitetos Antémio de Trales e Isidoro de Mileto. Numa obra de Procópio de Cesareia, De aedificiis, dispomos hoje de uma preciosa fonte para o estudo das quase cem igrejas construídas por Justiniano em todo o Império Bizantino, especialmente na capital. Também a fabulosa Basílica de São Vital de Ravenna (onde Justiniano e Teodora estão representados em mosaicos lindíssimos e que são hoje património mundial da Humanidade) foi concluída durante este reinado (em 547), assim como o impressionante Mosteiro de Santo Apolinário, em Classe (dois anos mais tarde). Justiniano, na opinião de Mischa Meier (2007 48-49), foi o imperador 
que melhor se serviu de um programa de obras públicas (sagradas e profanas) para concretizar a aspiração do soberano cristão: demonstrar devoção, amor ao próximo e preocupação com o bem do povo. Além de ter restaurado cidades tão emblemáticas como Antioquia ou Iustiniana Prima (o novo nome dado à sua terra natal), ele investiu fortemente em obras públicas e civis, como palácios, estátuas equestres, cisternas, orfanatos ou hospitais, pelo que esta vertente de edil do seu principado será para sempre recordada.

Em 541, a peste bubónica chegou (por via marítima) a Constantinopla, depois de ter atacado o Egito e a Palestina. Procópio diz que a doença, que teve o seu epicentro em 541/542 mas que se repetiu em ondas sucessivas até aos finais do século viII, de Roma à Escandinávia, dizimou metade da população do império; João de Éfeso, pelo seu lado, refere a ocorrência de 16000 mortos por dia na capital. Talvez os cronistas (que contam que as pessoas saíam de casa munidas de pulseiras com o seu nome, para que, caso morressem de repente, não acabassem anónimas numa vala comum) exagerem, mas parece razoável admitir um declínio demográfico de cerca de $25 \%$, com o litoral a ser mais afetado do que o interior do império (Meier 2007 75). Claro que a epidemia teve consequências devastadoras a todos os níveis: quebra do comércio, depreciação da moeda, colapso das infraestruturas, alterações no padrão de povoamento, escassez de mão-de-obra, subida dos preços, dificuldades de recrutamento militar, entre outras. As três variantes da doença (peste bubónica, pulmonar e septicémica) atuaram em conjunto e tiraram partido da fragilidade das condições de higiene pública, do fraco desenvolvimento dos recursos médicos e da fome. Tanto Procópio como Teófano referem que era difícil sepultar um número tão grande de mortos, e praticamente todos os cronistas (com exceção, talvez, de Agátias) consideraram a maleita como um castigo enviado por Deus. O pânico e a descrença alastraram, tanto mais que o próprio Justiniano contraiu a peste em 542 , chegando 
a discutir-se a sua sucessão: afinal, que imperador era aquele que não só não protegia o seu povo contra os Persas, os Búlgaros e as catástrofes naturais como ainda fora apanhado, ele próprio, pela doença?... Se o mundo não tinha acabado, o que explicava os desastres? Será que Deus estava zangado com o soberano?

Parecem ter terminado aqui os dias felizes de Justiniano, o "imperador insone" (isto é, que não dorme) que planeava febrilmente novas reformas, tentando controlar a corrupção, os abusos de poder e a compra de cargos, redefinindo a administração provincial, reforçando a assistência social, reorganizando as cidades e as províncias, conduzindo a guerra em diversas frentes... Todas as tensões vieram ao de cima, tanto mais que a ação do exército implicava enormes custos e agravava exponencialmente os impostos (João Lido fala em vinte e sete tipos de taxas!), não sendo possível disfarçar as dificuldades através de medidas de emergência pontuais (como o alívio fiscal, os subsídios ou o tabelamento de preços) ou com algumas boas notícias económicas, como aquela que resultou do desenvolvimento da indústria da seda, possibilitado pela introdução secreta em Bizâncio dos ovos do bicho-da-seda (em 551-552 e graças aos monges). Para além do mais, havia graves problemas na província de África (rebeliões no exército bizantino, com apoio berbere, vândalo e escravo, a obrigar a campanhas difíceis de Salomão e de João Troglita), e o esforço de guerra contra a Pérsia e na Itália não podia parar de repente, sob pena de um desastre humilhante.

Justiniano sobreviveu, mas começava a ficar cada vez mais sozinho e hesitante. Alguns dos seus mais valiosos generais, como Mundo ou Sitas, já tinham falecido, Triboniano foi apanhado pela peste de 542, João da Capadócia fora demitido no ano anterior e Teodora morreu em 548... Quinze anos após a Níka, o 'efeito de terror' desvanecera-se e a revolta voltava a grassar em Constantinopla, que em 557 ainda viu a cúpula de Santa Sofia desabar na sequência 
de um terramoto (Antémio de Trales faleceu por essa altura e já não pôde ajudar na reconstrução, iniciada em 562). Neste ambiente, os profetas anunciavam o fim do mundo, pululavam os movimentos ascéticos, cresciam a agitação e o pânico. Ainda por cima, também noutras regiões do império se avolumavam os problemas, com terramotos (p. ex., na Grécia central e no Mediterrâneo oriental, em 551), pestes, carestia, maremotos (p. ex., em Kios, em 551), inundações e épocas sucessivas de más colheitas (Meier 2007 94-95).

A resposta de Justiniano, um sexagenário no poder há já cerca de vinte anos, teve um cunho marcadamente religioso. Na segunda metade do seu longo principado, a política começou a subordinar-se à teologia e o imperador começou a escrever tratados com que intervinha abertamente nos grandes debates religiosos, ao mesmo tempo que depunha patriarcas e enfrentava o papa, que chegou a maltratar. Justiniano explorou a tradição oriental, que não separava nitidamente a Igreja do Estado, e convocou concílios onde tentou impor as suas ideias religiosas, regra geral de inspiração calcedónia. Em 543 e em 553, dois éditos imperiais condenaram a doutrina origenista (conciliação entre o neoplatonismo e o cristianismo, segundo Orígenes, teólogo da segunda metade do século III d. C.) defendida por Teodoro Askidas, um homem bastante fiel ao imperador. Cerca de 544 ou 545 , Justiniano produziu o seu primeiro tratado contra os chamados Três Capítulos, nome dado a outros tantos escritos suspeitos de nestorianismo devidos a Iba de Edessa, a Teodoro de Mopsuestia e a Teodoreto de Ciro (todos eles falecidos entre 428 e 466); neste contexto, o papa Virgílio foi raptado em Roma e levado para Constantinopla, onde foi forçado a condenar também aquela doutrina. Em 553, o V Concílio Ecuménico, reunido em Constantinopla sob a presidência de Eutíquio (patriarca da capital) e com muito escassa representação de bispos ocidentais, confirmou as preferências de Justiniano, que influenciou as decisões por meio de um poderoso discurso inaugural. Os patriarcas de 
Alexandria (Zoilo) e de Jerusalém (Macário) perderam mesmo os seus lugares, e o novo papa, Pelágio (556-561), um antigo defensor dos Três Capítulos, mudou de opinião sobre o assunto...

Em Itália, esta situação provocou um novo cisma e uma grande confusão, a nível civil e eclesiástico. O fervor religioso neocalcedónio do basileús, que queria evitar as interpretações monofisitas e nestorianistas, seguindo assim o pensamento de Cirilo de Alexandria (m. 444), levou-o ainda a intervir no debate interno dos Judeus sobre a língua em que deviam ser lidas as Sagradas Escrituras durante o ofício divino. Porém, curiosamente, em finais de 564 ou em inícios de 565, Justiniano promulgou um édito sobre o "aftartodocetismo", em que apoiava uma corrente monofisita minoritária, que defendia a ideia da imortalidade do corpo de Jesus; todos os patriarcas do Oriente se opuseram, e Eutíquio chegou mesmo a ser exilado; a questão só acalmaria depois da morte do imperador.

Como se vê, a política religiosa de Justiniano continuava a evidenciar algumas contradições, sendo no entanto permanente a intenção imperial de impor em todo o lado as suas preferências. Se as catástrofes que assolavam o Império Bizantino eram um castigo de Deus, então o soberano tinha de estar apto a corrigir a trajetória espiritual do seu povo e a mudar as consciências. Às críticas cada vez mais duras que lhe eram dirigidas em resultado de uma governação menos enérgica e muito errática (críticas essas que já não partiam só da velha elite senatorial, mas a que se juntavam agora intelectuais como Procópio, João de Éfeso, João Malala ou Romano Melodista), aos atentados e às conjuras (p. ex., em 549 e em 562, esta última a envolver injustamente Belisário), Justiniano respondia com uma verdadeira liturgização da vida política, social e cultural bizantinas (Meier 2007 106). Os protagonistas de comportamentos sociais desviantes, como os homossexuais ou os blasfemos, assim como os seguidores da antiga fé e os pagãos, 
foram convertidos em bodes expiatórios das desgraças do império e, como tal, foram perseguidos, tendo havido lugar a castigos públicos bem encenados, com queima de livros e de imagens e desfiles de condenados, entre outros.

Ao mesmo tempo, foram lançadas grandes campanhas missionárias (na Lazica, entre os Hunos e os Hérulos, no Cáucaso, no norte de África, na Núbia, na Etiópia) para eliminar o paganismo e integrar melhor as populações submetidas a Bizâncio; curiosamente, para este efeito, Justiniano recorreu à colaboração ativa entre ortodoxos e monofisitas. Incrementou-se a construção de edifícios religiosos (não só das igrejas de que já falámos, mas também de doze novos mosteiros) e ter-se-ão batizado perto de 70000 pessoas, explorando a ligação entre a peste e a conversão dos pagãos; as catástrofes geraram mudanças decisivas nas práticas religiosas do império, que assim foi ganhando também uma fisionomia cada vez menos 'romano-oriental' e cada vez mais 'bizantina'. Na Cítia, na primeira metade do século vi, o monge Dionísio-o-Exíguo introduziu o sistema cristão de contagem do tempo, com o início da datação "depois de Cristo". Enquanto isso, as cidades, sentindo-se mais abandonadas à sua sorte e vendo o imperador retirado no seu palácio, muitas vezes parecendo perdido no seu labirinto, partiram para o desenvolvimento da adoração das imagens protetoras (que consagrava a velha ideia da cidade como comunidade de culto) e estimularam a veneração de Maria, mãe de Deus, que se reputava ter salvado Constantinopla da destruição total, por alturas da peste bubónica. Justiniano, sempre muito astuto, estimulou estas novas devoções, que acentuavam a evolução da tradição clássica rumo à simbólica cristã, promovendo festas e procissões (como a Anunciação de Maria, a 25 de março), e desenvolveu uma outra estratégia, que passou pela sacralização do soberano, substituindo assim a dignidade imperial cristã da Antiguidade Tardia pela dignidade imperial bizantina. Na sua descrição da Igreja de Santa 
Sofia, em 562, Paulo Silenciário representa um soberano retirado do mundo terreno e que observa lá do alto, como Deus, os homens pecadores; Justiniano passava, assim, a surgir no papel de homem santo e asceta, próximo de Deus, taumaturgo e milagreiro, algo que Procópio, num passo da obra De Aedificiis $(1,7)$, repudia por completo e relaciona com a natureza demoníaca do imperador (Meier 2007 103).

Finalmente, em 14 de novembro de 565, Justiniano faleceu, de morte natural, aos 83 anos de idade, sendo sepultado na Igreja dos Santíssimos Apóstolos, envolto num sudário onde estavam representados os inimigos que derrotara, a cidade de Roma e ele próprio, com os pés assentes na cabeça de Gelimero, o rei dos Vândalos! Passara trinta e oito anos a governar o Império Bizantino, de que foi sem dúvida o mais célebre titular. Deixou uma obra imensa em todos os domínios e também com implicações do ponto de vista cultural, graças ao desenvolvimento da historiografia grega de tipo erudito (com Procópio de Cesareia), da historiografia popular em grego (com a Cronografia de João Malala, que se estende das origens do mundo ao tempo de Justiniano, num registo analítico, religioso e político), da historiografia latina (p. ex., com a Crónica do comes Marcelino), ou da própria literatura (com Agátias de Mirina, João Lourenço Lido, Cirilo de Citopólis, Flávio Crescónio Coripo, entre outros autores). Porta-voz da aristocracia ortodoxa, poucos the perdoarão, todavia, o encerramento da velha Academia de Atenas (escola prestigiada, de matriz platónica), acusada de paganismo impenitente (Kaplan 1991 18)...

A sucessão de Justiniano, que não teve filhos de Teodora e que não parece ter dado indicações a respeito de herdeiros, coube ao seu sobrinho Justino (filho da irmã Vigilância), que era kouropalátēs (alto funcionário palatino, com especiais responsabilidades no domínio militar) e que tinha, portanto, grande influência no palácio imperial, sendo além disso casado com uma sobrinha de Teodora, 
chamada Sofia. Justino II (565-578) foi prontamente coroado pelo patriarca João III Escolástico e aclamado no Hipódromo. Tanto quanto referem as fontes (Coripo, Agátias, Menandro, Protetor), o novo imperador lamentou o preço exorbitante da política externa do seu antecessor (fazer a guerra em diversas frentes, comprar a paz à força de tributos pesadíssimos) e o estado do exército. Logo em 569, uma contraofensiva visigoda na Hispânia acabou por levar à expulsão dos Bizantinos da Península Ibérica. Pressionado, Justino II procurou reduzir os custos da guerra, evitando pagar o tributo aos Ávaros e aos Persas, e até reconquistou Sirmio, mas a nova orientação minimalista revelou-se fatal, com os Persas a atacarem de novo (conquista de Dara, em 573) e o novo imperador a ter de desguarnecer a fronteira norte para reagir, possibilitando com isso o avanço dos Ávaros, que, numa espécie de efeito de bola de bilhar, acabaram por empurrar os Lombardos para o Ocidente.

Os Lombardos tinham entrado na órbita do Império Romano ainda no século I, no norte da Germânia; em 489, fixaram-se a norte do Danúbio e, depois, mais a leste, estabelecendo-se na antiga Panónia (atual Hungria); eram considerados guerreiros extremamente ferozes e Narsés até tinha utilizado 2500 desses homens como mercenários na guerra contra os Godos, mas teve de os recambiar devido aos excessos que cometiam. A invasão lombarda da Itália deu-se em 568, logo que Justino II substituiu Narsés pelo prefeito Longino. Talvez a motivação para a migração deste povo germânico tenha de facto tido que ver com a perigosa vizinhança dos Ávaros após a eliminação, em 567 e pelos próprios Lombardos, do reino dos Gépidos, favorecidos por Justino II. Certo é que os Lombardos (e outros contingentes bárbaros) entraram nos Alpes Julianos em maio de 568, penetrando na planície do Véneto sem oposição bizantina: a peste debilitara o império, que dispunha de poucas tropas móveis e que não contava com um comando centralizado na região; é também possível que tenha havido a expectativa de 
um acordo inicial entre ambas as partes contra um inimigo comum - os Francos; no fundo, e como habitualmente, Bizâncio começou por utilizar uma estratégia defensiva, evitando as batalhas campais e preferindo a via diplomática (Luttwak 2009 passim). Contudo, até ao início de 570, o rei lombardo Albuíno conquistou toda a região entre os Alpes e o rio Pó (Friuli, Treviso, Verona, Milão), tendo Pádua resistido até 572; neste ano, Albuíno foi assassinado e substituído por Clefi, talvez com a ajuda do prefeito Longino. Dois anos mais tarde, foi a vez de Clefi ser abatido, seguindo-se dez anos de anarquia, que contudo não travaram a conquista lombarda, e com uma profundidade tal que levou à formação dos ducados de Espoleto e de Benevento. O grande porto de Ravenna, Classe, fundado por Júlio César, caiu em 578; dois anos antes, Justino II enviara um forte exército, sob o comando de Baduário, mas este fora derrotado e morto em batalha (Ravegnani 2006 51-52). De uma forma geral, o litoral resistiu melhor do que o interior, pois ali as cidades bizantinas podiam beneficiar de algum apoio marítimo. Todavia, os Lombardos vieram para ficar, e não é por acaso que, ainda hoje, a mais importante província do norte de Itália, com as grandes cidades industriais, se chama Lombardia.

Também as novas iniciativas do sucessor de Justiniano relativamente ao monosifismo não surtiram efeito, degenerando em perseguições pesadas. Afetado por uma doença mental, Justino II foi delegando cada vez mais as suas tarefas na imperatriz Sofia e, em 574, acabou por nomear o comes excubitorum, Tibério, como seu kaîsar, acelerando assim a sua própria sucessão. Tibério I, que Justino II tornaria augusto no seu leito de morte, foi imperador apenas durante quatro anos (de 578 a 582), e no seu tempo os Ávaros estavam a estender-se para a Hungria, desde a Boémia até ao Danúbio, tendo acabado por formar um grande império, ao dominarem populações búlgaras, gépidas e eslavas. Os Ávaros tinham uma grande capacidade militar, sendo-lhes mesmo imputada 
a generalização do estribo de montar no Ocidente europeu, mas ainda preferiam o saque à ocupação territorial.

Já os Eslavos, protagonistas de uma migração notável, optaram por uma fixação estável em território imperial, o que conduziu à eslavização da Península Balcânica, com a população indígena a desaparecer ou a fugir para a costa ou para as ilhas (assim dando origem à chamada Eslavínia). Quase todo o centro e o norte dos Balcãs foram ocupados pelos Eslavos, pelo que Tibério decidiu fazer-lhes face aliando-se aos Ávaros; porém, a aliança durou pouco tempo e, em 580, os Ávaros capturaram Sirmio (a peça chave para o acesso à zona noroeste dos Balcãs), após um cerco de dois anos. No ano seguinte, os Eslavos atacaram em força e penetraram na Trácia, na Macedónia e na Grécia, fixando-se por ali; juntamente com os Ávaros, semearam o terror e, nos inícios dos anos 580, atacaram por duas vezes Tessalónica, a grande cidade bizantina da região. A Bizâncio (que, sem capacidade para reagir, praticamente entregou a defesa à população local) restavam agora, nesta geografia, as cidades costeiras do Adriático e do mar Negro, Tessalónica (rodeada de Eslavos) e, claro, Constantinopla, que assegurava um domínio precário sobre a zona vizinha da Trácia; já no sul da Península Balcânica, a Tessália, o Epiro e o Peloponeso ocidental foram profundamente eslavizados, com Bizâncio a controlar apenas alguns pontos a que conseguia aceder por via marítima (Ravegnani 2006 56-58).

Foi neste contexto, extremamente delicado, que assumiu o poder, em 582, um grande general da Capadócia, chamado Maurício (582-602), que fora comes excubitorum e augusto do seu antecessor. Maurício, homem de grande capacidade militar e que escreveu um tratado de arte bélica notável, Strategikon, onde, escorado na melhor tradição romana (nomeadamente em Flávio Vegécio Renato, tratadista latino que escreveu por volta do ano $400 \mathrm{~d}$. C.), resumiu os princípios básicos da ciência militar bizantina, governou 
longamente. Coube-lhe fundar, em 584, o exarcado de Itália (ou de Ravenna), com um modelo administrativo semelhante ao do exarcado da África bizantina, ou seja, com base na militarização do território e com supremacia do poder militar sobre as autoridades políticas: devido às conquistas lombardas, o ambiente era de guerra permanente, lembrando em parte aquilo que acontecerá na Península Ibérica medieval, com o regime das "frontarias". O exarco de Ravenna dispunha, pois, de poderes excecionais, que exercia através dos magistri militum, dos duces e dos tribuni; a sua autoridade estendia-se a tudo o que restava de Bizâncio em Itália (cerca de um terço da península), mas a Sicília e a Sardenha ficavam de fora, sob uma outra jurisdição. Os exarcos eram escolhidos pelo basileús e elevados à condição de patricius; geralmente, eram eunucos, para evitar a tentação das usurpações de poder (em Bizâncio, considerava-se que homens fisicamente deficientes ou mutilados não podiam governar). $\mathrm{O}$ exarcado de Ravenna durou até 751, estimando-se que, ao longo destes 167 anos, tenha havido cerca de 24 exarcos. Em finais do século vi, o exarcado de Itália incluía os seguintes territórios: o litoral da Ligúria e parte da costa da Toscana, a Ístria e uma parte do Véneto, o exarcado propriamente dito, com centro em Ravenna, o ducado do Pentapoli (Rimini, Ancona, Urbino, Gubbio), o litoral do Abrúzio, o ducado de Perúgia (vital, porque ligava Ravenna a Roma, depois do corte, em vários pontos, da Via Flamínia pelos Lombardos), o ducado de Roma, o ducado de Nápoles e a Campânia (com a zona costeira de Cuma a Salerno) e as províncias da Apúlia, da Lucânia e do Brútio - a futura Calábria, no extremo sul da península (Ravegnani 2006 53-55).

Em 591, na Pérsia, deu-se o assassinato do rei Hormisdas, e o seu filho Cosroés II fugiu para Bizâncio e solicitou o auxílio de Maurício. O imperador correspondeu ao pedido e efetuou uma campanha a oriente, com o seu aliado, da qual resultaram bons 
dividendos para Bizâncio. A seguir, com a paz feita na Pérsia e a situação italiana estabilizada, Maurício pôde transferir tropas para os Balcãs, onde se assistiu a uma grande recuperação bizantina, com a reconquista de Belgrado e a assinatura de um tratado com os Ávaros, em 600, fixando a fronteira no rio Danúbio. Era necessário restabelecer as comunicações com o Ocidente e reabrir o grande eixo terrestre, a chamada Via Egnacia, que ligava Dirráquio (na costa oriental do mar Adriático) a Tessalónica e a Constantinopla. O exército bizantino chegou mesmo a invadir o território adversário e a forçar a retirada do khan Baian; no entanto, as tropas imperiais começavam a acusar alguma saturação e revoltaram-se quando Maurício decidiu reduzir os seus salários e estabelecer os acampamentos de inverno em região muito perigosa, a norte do rio Danúbio. Em 602, um oficial da armada danubiana, chamado Focas, foi proclamado imperador pelos soldados e marchou sobre Constantinopla; Maurício fugiu com uma parte do tesouro e com a família, mas foi apanhado na fuga e cruelmente executado, juntamente com os quatro filhos; ao que parece, as infiéis milícias do Hipódromo (os Verdes e os Azuis) pouco fizeram para proteger o seu imperator... Já Cosroés II da Pérsia foi mais 'solidário' e, a pretexto de vingar o seu antigo aliado, aproveitou para invadir a Arménia e a Mesopotâmia, onde conseguiu derrotar repetidamente os Bizantinos e penetrar profundamente na Ásia Menor. Quanto a Focas, só se manteria por oito anos no poder (de 602 a 610); teve de suportar muitas revoltas (como a de Narsés, magister militum per Orientem, que também queria vingar Maurício), as quais reprimiu com extrema brutalidade; contudo acabou, também ele, por ser derrubado e morto, em 610, na rebelião encabeçada pelo exarco de África, o notável comandante Heráclio.

Quatro imperadores, portanto, governaram Bizâncio nos quarenta anos que se seguiram à morte de Justiniano, e todos sentiram grandes dificuldades: crise financeira, herança pesada, muitas 
frentes para defender em simultâneo (no Ocidente e no Oriente). À entrada do segundo período da história de Bizâncio, a situação não se afigurava nada fácil para o grande império herdeiro de Roma!

\subsection{A época médio-bizantina, desde 610}

(início da dinastia heracliana) até 1204

(conquista de Constantinopla pelos cruzados):

Heráclio (610-641) iniciou uma nova etapa da história bizantina e deu mesmo origem a uma dinastia, que se prolongou até 711 (o ano em que os Árabes invadiram a Península Ibérica) e que incluiu uma dezena de imperadores. No início, a grande preocupação foi, claro está, defender o território da ameaça dos Persas, dos Ávaros, dos Eslavos e, a breve trecho, dos Árabes e dos Búlgaros. Contudo, a dinastia heracliana também ficou para a História porque, devido às suas reformas administrativas e dos costumes, ajudou a orientalizar o Império e a dar-lhe uma fisionomia mais fortemente 'bizantina'. Foi nesta altura que a língua grega se impôs como língua oficial e que se deu o desaparecimento de várias magistraturas tardo-romanas essenciais: a prefeitura do pretório, por exemplo, caiu ao longo do século vir, dando lugar aos vários departamentos dos sếkrēta (isto é, às várias repartições da administração central), chefiados pelos logótetas (aqueles que "dão ordens", que "registam"). Do mesmo modo, o praepositus sacri cubiculum viu as suas competências fragmentadas, e o comes sacrorum largitionum, que se ocupava das finanças, foi substituído pelo sakkellários, cujos serviços estavam repartidos entre diversos sékrēta ${ }^{1}$. Curiosamente,

\footnotetext{
1 O logóteta do genikón tinha autoridade fiscal sobre o conjunto do território para cobrar o imposto e enviava para as províncias os seus recenseadores (para atualizarem os cadastros) e os seus cobradores; dele dependiam os fiscais alfandegários. Já o logóteta do stratiōtikón ocupava-se do recrutamento e do financiamento
} 
o magister officiorum sobreviveu, mas apenas honorificamente (um sinal do típico conservadorismo bizantino), mas as suas atribuições foram de facto repartidas entre diversos oficiais, desde o logóteta do drómos (o correio oficial, que tratava da manutenção das estradas, da transmissão das mensagens e da recolha de informações secretas, sendo também a ele que competia receber os embaixadores estrangeiros) até ao domestikós dos scholae (o chefe da guarda dos scholae palatinae) e aos questores (para controlo dos officia palatinae).

No Grande Palácio, além dos serviços colocados sob a autoridade do parakoimómenos (que vigiava a câmara imperial e que, por essa razão, foi durante muito tempo um eunuco, sendo uma das personagens mais poderosas do império) e do prōtobestiários (habitualmente também um eunuco, que era responsável pelo guarda-roupa imperial e um homem muito próximo do imperador), o basileús (um termo que se impõe a partir de Heráclio, substituindo o de imperator) dispunha de outros colaboradores bastante próximos, como por exemplo o prepósito do tinteiro (epi tô̂ kanikleíou), que lhe apresentava as crisobulas (o mais solene dos documentos emitidos pela chancelaria imperial, datado e assinado pela mão do imperador com tinta púrpura e selado por uma bula de ouro) e os restantes atos imperiais. Os documentos eram preparados na chancelaria, dirigida pelo prōtoasēkrêtēes, ele próprio secundado por uma série de notários; ao epì tôn deếseōn competia estudar os requerimentos apresentados ao imperador. Ao mesmo tempo, o éparchos (ou prefeito) de Constantinopla viu

\footnotetext{
dos exércitos, enquanto o prepósito sacelário se encarregava do tesouro do Estado e o prepósito do vestiário público guardava os metais preciosos e as armas. Pelo seu lado, o prepósito do eidikón pagava as rógai (remuneração, em numerário ou em tecidos preciosos fornecidos pelas oficinas imperiais, atribuída uma vez por ano, por altura da Páscoa, aos dignitários do império, segundo a sua hierarquia própria) e supervisionava as oficinas imperiais. A estes serviços, acrescentavam-se os curadores, que administravam o domínio privado do imperador.
} 
reforçadas as suas competências, tornando-se a personagem mais importante da capital, a seguir ao basileús; assumia a administração municipal, a polícia, o controlo dos aprovisionamentos, dos preços e, por fim, a vigilância dos estrangeiros presentes em Constantinopla. Dada a redução do espaço do Império Bizantino, no século vil verificou-se uma restrição do número de funcionários e uma maior concentração de recursos e de elites na capital (Cheynet 2001 77-78).

Aos heraclianos está também associada a reforma militar que deu origem ao célebre regime dos "témata" (do grego théma, que significa corpo armado, ou da palavra turca toumen, que designava uma divisão de 10000 homens). A primeira lista oficial conhecida de témata data de 687, correspondendo a um documento de Justiniano II (685-695) destinado ao papa, confirmando as atas do VI Concílio Ecuménico (reunido em 680). Os témata (singular théma ou "tema"; plural thémata ou "témata") constituíram a espinha dorsal do Império Bizantino no período intermédio da sua história e, segundo alguns estudiosos, corresponderam a uma mudança de paradigma radical: eram novos distritos administrativos, que implicaram uma deslocação de forças militares numerosas sob o comando de um stratēgós que acumulava autoridade civil e militar, o que pressupôs o abandono da separação tardo-romana clássica entre o poder civil e o poder militar e a afirmação da militarização do território (já ensaiada com os exarcados de África e de Ravenna), de maneira a garantir a sobrevivência das conquistas imperiais (Ravegnani 2006 59-61; Cheynet 2001 81-82).

Parece existir algum consenso sobre a generalização deste modelo ao longo da segunda metade do século viI, na Ásia Menor, após o ataque dos Persas ou a seguir à grande investida árabe. Nessa altura, haveria apenas o tema dos Anatólicos (ou seja, dos orientais, desde 669), o dos Arménios (desde 667) e o do Opsíkion (nome de uma unidade militar de elite tradicionalmente consagrada 
a defender Constantinopla, desde 680$)^{2}$, para além do tema marítimo dos Carabisiani (na costa sul da Ásia Menor, desde 680-690). Depois, o sistema ter-se-á alargado aos territórios reconquistados e à Europa, no extremo final do século viI, com a criação dos témata da Trácia e da Hélade. Na segunda parte deste volume, voltar-se-á a este assunto.

Giorgio Ravegnani, professor em Veneza e um dos mais ilustres bizantinistas italianos da atualidade, considera que o regime dos témata "revolucionou a administração provincial, superando o intrincado sistema tardo-romano das prefeituras, dioceses e províncias variadamente subdividido nos novos distritos dependentes do governo central"; este investigador pensa também que o novo modelo, ao assegurar a proeminência do comando militar, permitiu "fazer frente de maneira mais eficaz à pressão inimiga sobre a fronteira, oferecendo um válido dispositivo defensivo que contribuiu para garantir a sobrevivência de Bizâncio" (Ravegnani 2006 61).

De acordo com a interpretação clássica, sugerida por Georges Ostrogorsky (1963) e parcialmente perfilhada por Ravegnani e por Kaplan, criou-se deste modo um novo tipo de exército, assente em soldados-colonos (stratiôtai), a quem o Estado garantia terra em troca de serviço militar obrigatório, assim se reformando o decadente modelo tardo-romano dos limitanei, as tropas fronteiriças de segunda classe, que Justiniano já desmobilizara. O novo sistema, aplicado em larga escala, terá sido duplamente vantajoso, uma vez que, por um lado, libertou o império da custosa manutenção de um exército de profissionais e, por outro, assegurou um exército sólido de soldados-colonos motivados para defender o território. A ocorrência de sucessivas vagas invasoras (a que adiante faremos

\footnotetext{
2 No caso do tema do Opsíkion, por se tratar da defesa da capital, o comando estava entregue a um kómēs (conde, um título que, tal como o de domestikós, era conferido aos chefes dos regimentos da guarda) e não a um stratēgós.
} 
referência) terá facilitado ao Estado a redistribuição de terras em proveito do novo exército, ao mesmo tempo que a formação de uma classe civil de pequenos camponeses livres, organizados em comunidades aldeãs, também ajudou, na medida em que proporcionou uma boa base produtiva e fiscal (Ravegnani 2006 61-62; Kaplan 1991 43).

Nem todos os especialistas, porém, estão de acordo com esta interpretação. Um prestigiado bizantinista francês, professor na Sorbonne, Jean-Claude Cheynet, por exemplo, considera esta visão excessivamente romântica e influenciada pela condição vivencial de Ostrogorsky, professor em Belgrado após a Segunda Guerra Mundial e com tendência para projetar sobre o passado o exemplo recente da resistência popular aos Alemães, seduzido pela ideia do soldado-camponês que lutava pela sobrevivência da sua pátria (Cheynet 2001 82). Este investigador francês recorda que, no século $x$, o imperador Constantino VII Porfirogeneta atribuiu a criação dos témata ao imperador Heráclio; segundo a tese clássica, este imperador teria dividido a Ásia Menor em grandes circunscrições e teria reconstruído o exército bizantino, combinando a instituição dos limitanei com a organização dos exarcados e fixando os soldados à terra (as chamadas "terras estratióticas") em troca da garantia de um serviço militar hereditário, o que teria permitido a Heráclio levar de vencida os seus inimigos em pouco mais de três anos. Ora, para Cheynet, esta ideia (apoiada em interpretações bastante discutíveis de passagens do cronista Teófano) não tem fundamento: "uma tal organização não teria podido produzir os seus frutos em tão curto espaço de tempo, e a documentação prova que o imperador, até ao final do seu reinado, recrutou segundo as modalidades tradicionais". Ora, mais do que a datação precisa da reforma, o que está em causa é a sua verdadeira natureza: "o nome que os témata tomaram explica-se pela origem das tropas (...). Assim, vê-se claramente que é o antigo exército central, estabelecido sobre 
novos territórios, que esteve na origem dos témata. (...) Após várias décadas, os novos soldados foram recrutados no seio do respetivo corpo do exército e o tema designou então uma circunscrição administrativa que se substituiu, em pouco mais de um século, às velhas províncias romanas e que sobreviveu até ao fim do Império" (Cheynet 2001 83).

Assim, segundo o mesmo autor, o que realmente explica a reforma dos témata terá sido a necessidade de manter tropas o mais numerosas possível, tendo em consideração a ameaça árabe e as dificuldades financeiras do Estado (o fundador da dinastia heracliana chegou a ter de fundir o tesouro das igrejas, à falta de numerário no Tesouro imperial), muito agravadas pela perda das províncias orientais, nomeadamente do Egito, que garantiam uma boa receita fiscal; deste modo, "foram repartidas tropas por províncias que, até então, estavam praticamente desprovidas delas. A sua dispersão não correspondia a um projeto estratégico, mas à necessidade de obter para elas, com menos custos, o abastecimento, aproximando-as dos camponeses produtores que pagavam o seu imposto em géneros" (Cheynet 2001 83). Quanto às "terras estratióticas", não parece sustentável admitir que os soldados tenham, no decurso deste processo, recebido terras para cultivar; a ideia é atraente, mas, para que o sistema funcionasse, seria preciso que os soldados tivessem aptidão para o trabalho nos campos, tempo para o executar e famílias numerosas para os substituir durante as suas longas ausências... Além disso, não é verosímil que o Estado dispusesse de reservas fundiárias em quantidade suficiente para distribuir por dezenas de milhares de soldados, muitos dos quais se sabe, de resto, que ficaram reduzidos à pobreza, o que não teria sucedido se dispusessem de uma alternativa de vida de base agrícola (facto que os poucos textos anteriores ao século x nem sequer sugerem). Em contrapartida, é certo - afirma Cheynet - que "a família era obrigada a fornecer um soldado; era uma obrigação 
pessoal hereditária, em troca de uma vantagem fiscal para o lar. Uma família faltosa deveria assegurar uma compensação para o Estado. (...) Os soldados recebiam ainda algumas peças de ouro, numa época em que estas representavam um forte poder de compra, e estavam em condições de adquirir terras, tanto mais que permaneciam sempre nas mesmas aldeias, ou nos mesmos kástra (acampamentos). Eles constituíam bons partidos e acabaram por se misturar com os nobres locais, tornando-se, por sua vez, os mais felizes de entre eles, proprietários fundiários entre o século vil e o século Ix" (Cheynet 2001 83-84).

Penso que esta interpretação de Jean-Claude Cheynet repõe alguma verosimilhança na reconstituição da reforma dos témata. Resta acrescentar que a eficácia demonstrada por eles não fez esquecer de todo a importância de dispor de um bom exército central. Assim que voltaram a ter condições para pagar um soldo anual regular, os imperadores, sem abolir os témata, reconstituíram um exército central formado por profissionais, sempre mobilizável e, contrariamente aos corpos militares dos témata, capaz de intervir longe dos seus aquartelamentos. Imperadores como Constantino $\mathrm{V}$ (741-755) dedicar-se-ão com entusiasmo à criação de um exército central desse tipo, nomeadamente devolvendo a certos regimentos da guarda o seu papel militar: foi o que sucedeu com o tágma dos Scholes, cujo chefe, o domestikós dos Scholes, adquiriu aos poucos o estatuto de Chefe do Estado-Maior, tornando-se mais tarde o substituto do basileús à frente dos exércitos ${ }^{3}$. Nos séculos x e xI, como perceberemos melhor mais adiante, a tendência acentuou-se, pois os témata começaram a revelar menor combatividade e os soldados passaram a preferir pagar um imposto em vez de servirem

\footnotetext{
3 Tagma (plural: tágmata): contingente do exército central, incluindo os da guarda imperial; eram comandados pelos duques ou katepánō. Scholes: regimento de elite, que guardava o palácio imperial.
} 
na guerra, o que forçou os imperadores a contratar profissionais, entre eles muitos estrangeiros (Búlgaros, infantaria russa, arqueiros arménios, cavaleiros latinos e outros). Esta gente obedecia a quem lhe pagava (ou seja, ao imperador) e foi com este exército compósito que foram reconquistadas as províncias do Oriente e a Bulgária, nomeadamente graças ao célebre regimento russo dos Varegues ou Varangianos, um corpo da guarda palatina constituído por Basílio II (963-1025), um imperador macedónio de quem muito falaremos na altura própria (Cheynet 2001 84-85).

Mas regressemos a Heráclio e recordemos os acontecimentos político-militares mais decisivos do seu reinado de trinta e um anos, iniciado em 610 com a deposição e morte de Focas. O antigo exarco de África assumiu o poder debaixo de uma verdadeira chuva de ameaças, em especial nos Balcãs, com as invasões ávaro-eslavas (rumo ao Adriático, ao Egeu e ao Bósforo) e o cerco falhado de 626 a Constantinopla (defendida pelo magister militum praesentalis Bono, com o auxílio do patriarca Sérgio); incapaz de superar as fortes muralhas e impotente perante o poder naval bizantino, o khan ávaro acabou por se retirar, mas o problema balcânico prosseguiu, com a expansão eslava e, depois, a fixação dos Sérvios e dos Croatas, que só reconheciam a soberania bizantina de um ponto de vista formal. Também os Persas aproveitaram para atacar e conseguiram ocupar a Arménia e a Ásia Menor, tendo capturado Jerusalém logo em 614 (levando a preciosa Vera Cruz de Jesus Cristo para Ctesifonte); em 619, foi a vez de tomarem o Egito.

Heráclio reagiu e, invertendo a estratégia tradicional bizantina, passou ao ataque, obtendo um grande sucesso na Arménia (em 624) e destruindo a hoste persa diante de Nínive, em 627; no ano seguinte, os Persas capitularam, tendo sido assinado um tratado de paz com o rei Xeroé (que eliminara o pai, Cosroés II): foi o fim das guerras romano-pérsicas, assinalado com o regresso triunfal da Vera Cruz. 
Muito mais graves e duradouros foram os problemas causados pela expansão muçulmana: Maomé unira as tribos árabes (recorde-se que a Hégira ocorreu em 622) e, após a sua morte, os califas atacaram a Pérsia e Bizâncio. A primeira guerra islâmica deu-se no Iraque, então sob o domínio persa, e conduziria ao assassinato do derradeiro monarca sassânida, em 651. Contra Bizâncio, as operações começaram em finais de 633 e geraram diversas vitórias militares muçulmanas, a mais célebre das quais obtida no rio Yarmouk (um afluente do Jordão, a sul de Tiberíades), em 636. Num estilo de autêntica Blitzkrieg, os Árabes conquistaram a Síria e a Palestina, tomando Jerusalém em 638 e Cesareia dois anos mais tarde; seguiram-se a Mesopotâmia (em 639-641) e uma parte da Arménia (640); em 639-640, foi a vez do Egito e de Alexandria! A exaustão do exército imperial, o entusiasmo dos conquistadores e $o$ apoio que recolheram entre as comunidades monofisitas ajudam a explicar esta onda de vitórias muçulmanas (Ravegnani 2006 65-66).

Heráclio procurou então aproximar os calcedónios dos monofisitas, uma estratégia que conduziu à formulação de duas novas doutrinas conciliadoras, por iniciativa do patriarca Sérgio: o monoenergismo, segundo o qual Cristo tem duas naturezas mas um só princípio de ação ou força agente (enérgeia); e o monotelismo, doutrina que reconhece em Cristo uma só vontade, para além da dualidade das suas naturezas. Em finais de 638 ou em inícios de 639, o édito imperial Ékthesis impôs o monotelismo, mas foi um fracasso: os monofisitas não aderiram, e o decreto suscitou uma oposição violenta em Roma, onde o papa Martinho I fez convocar um concílio, reunido no palácio de Latrão e sem aprovação imperial, o que constituía uma afronta; os bispos do Oriente, sob o impulso de Máximo (um monge de Leste) condenaram o monotelismo e excomungaram o patriarca de Constantinopla. Como represália, o basileús, através do exarco de Ravenna (Isácio) e do titular da circunscrição militar de Roma (Maurício), baniu os 
principais dignitários da Igreja romana e confiscou os seus bens; além disso, o papa Martinho e o monge Máximo foram transferidos para Constantinopla e deportados (o Sumo Pontífice quase foi executado, tendo sido depois exilado na Crimeia)!

Entretanto, após a perda das províncias orientais bizantinas, não foi mais necessário conservar o monotelismo, concebido para as unir... Em conformidade, a doutrina seria condenada no VI Concílio Ecuménico, reunido em Constantinopla em 680-681, e só os maronitas da Síria perseveraram na sua defesa. Como observa Cheynet, esta longa crise religiosa revelou que era impossível pôr de acordo, simultaneamente, sobre uma mesma doutrina religiosa, Roma e as igrejas monofisitas do Oriente; mostrou ainda a oposição violenta de uma corrente da Igreja (representada pelo monge Máximo) a toda a intervenção imperial em matéria de doutrina. No entanto, as divergências entre Roma e Constantinopla não devem ser exageradas, pois o sentimento de unidade cristã era ainda largamente predominante (Cheynet 2001 52-53).

A sucessão de Heráclio foi complicada, porque o seu primogénito, Constantino III (641), morreu três meses depois. A segunda esposa de Heráclio, Martina, assumiu a regência em nome do filho, Heraclonas, mas estes tornaram-se muito impopulares e foram derrubados pelo próprio Senado e mutilados. O poder passou então para um filho de Constantino III, chamado Constante II (641-668), que só tinha 11 anos de idade, tendo o Senado exercido a regência e recuperado, assim, algum do protagonismo que perdera ao longo dos tempos.

Os Árabes estavam então no auge da sua expansão, e o Egito bizantino foi abandonado quase sem combate, apesar de ser uma das províncias mais ricas do império; em 645, a frota imperial ainda recuperou Alexandria, mas foi um sucesso passageiro, tanto mais que, no Egito, a dominação muçulmana parece ter sido bem recebida pela população. Por esta altura, os Árabes estenderam 
a sua expansão à costa norte-africana (Trípoli), à Arménia (em 642-643) e à Ásia Menor (Cesareia da Capadócia e Frígia) e, com o califa Othman (a partir de 644), tornaram-se uma potência naval, o que lhes garantiu as capturas de Chipre, de Rodes e de Cós. Em 655, a frota imperial foi estrondosamente derrotada junto à Lícia, numa batalha naval que assinalou o fim da talassocracia bizantina.

Nos anos seguintes, devido ao assassinato de Othman em 656 e à guerra civil árabe que se seguiu durante um lustro, Constante II pôde respirar melhor e obteve um sucesso importante nos Balcãs, ao atacar os Eslavos em 658; recuperou alguns territórios, viu a soberania bizantina reconhecida na Macedónia e procedeu também a algumas deportações para a Ásia Menor, procurando integrar os visados nas fileiras do exército bizantino.

Para melhor enfrentar os Lombardos, e também os Árabes que ameaçavam a Sicília, Constante II transferiu a sede de governo para a Itália (uma opção muito contestada em Constantinopla). Foi bem acolhido pelo papa Vitaliano (657-672), que saudou esta primeira visita de um basileús ao Ocidente depois de 476, mas sofreu alguns desaires militares e acabou por ser assassinado em Siracusa, em 668 , em resultado de uma política fiscal muito dura e de um estilo de governação demasiado repressivo. Ruíam assim, simultaneamente, o projeto bizantino de colocar o Ocidente no centro da política imperial e a última tentativa de Constantinopla para recuperar o domínio sobre o sul da Península Itálica (Ravegnani 2006 70).

Constantino IV (668-685), ao subir ao trono, tratou logo de mutilar os seus irmãos (Heráclio e Tibério) para evitar partilhar o poder. Dois acontecimentos marcaram o seu reinado: por um lado, o cerco árabe a Constantinopla, a partir de 674, que durou perto de quatro anos e que fracassou devido à utilização, pelos sitiados, do célebre fogo greguês, uma substância muito pegajosa (possivelmente inventada por monges e arremessada por sifões pressurizados) que combinava resina de pinheiro, nafta, cal e 
enxofre ou salitre e que tinha a particularidade extraordinária de arder na água; por outro, a formação do Império Búlgaro, cerca de 680, na antiga Mécia e na Cítia (a nordeste do mar Negro). Os Búlgaros terão sido empurrados para sudoeste pelos Khazares (uma população das estepes do sul da Rússia, à qual foram parcialmente submetidos) e cruzaram o rio Danúbio, submetendo os Eslavos que aí se encontravam. Bizâncio tentou travar, logo desde o início, este processo, com uma campanha por mar e por terra, que terminou com muitas baixas e com a doença do próprio imperador. Constituiu-se então um Estado búlgaro entre o Danúbio e as montanhas balcânicas, o que significa que, pela primeira vez, se formou um império independente em território bizantino (Ravegnani 2006 73)! Constantino IV foi obrigado a reconhecer esta realidade e a assinar um tratado de paz com uma nova grande potência, que durante séculos ameaçaria Constantinopla; as tribos eslavas tiveram de pagar um tributo, mas, aos poucos, fundir-se-iam com os novos ocupantes, dando origem a um único povo eslavo-búlgaro.

Justiniano II (685-695 e 705-711) assumiu o trono à morte do pai, com a particularidade de ter reinado por duas vezes e de ter encerrado a dinastia heracliana. Começou por obter alguns sucessos nos Balcãs, mas a retomada infeliz da guerra contra os Árabes, em 691, conduziu a uma revolta que levou à sua deposição em 695, à sua mutilação (foi-lhe cortado o nariz) e à sua deportação. Assumiu então o poder o estratego do tema da Hélade, Leôncio (695-698), mas os Árabes conquistaram Cartago (nada menos do que a capital do exarcado de África) e a frota bizantina amotinou-se, proclamando imperador o almirante Absimaro, que subiu ao trono púrpura com o nome de Tibério II (698-705). Porém, a instabilidade continuou e permitiu a Justiniano II recuperar o trono, com a particularidade (premonitória) de o ter feito com a ajuda dos Búlgaros e do khan dos Khazares, onde se refugiara e cuja filha esposara! Tibério e Leôncio foram capturados e mortos, dando o tiro de partida para 
um regime de terror orquestrado pelo vingativo Justiniano II, o que em 711 conduziu a uma revolta generalizada do exército, da marinha e da população, a partir de Cherson: o imperador foi assassinado e o arménio Filipico Bardanés (711-713) foi proclamado imperador.

A mudança de dinastia não trouxe a bonança a Bizâncio. Ainda com Justiniano II, tinham-se reaberto os problemas com a Igreja de Roma, pois o Concílio Trulano de 692 tomara decisões contrárias ao culto romano, em matéria de casamento do clero e de jejum de sábado, o que suscitara a oposição do papa Sérgio I (687-701) e novos conflitos com as autoridades bizantinas em Itália. Os Lombardos aproveitaram o contexto e assaltaram as possessões bizantinas na Campânia, avançando depois sobre Roma, onde o papa João VI (701-705) os convenceu a retirarem-se. Visivelmente, o exarcado de Ravenna, sob a tremenda pressão lombarda, entrara em decadência profunda, agravada pela influência de uma Igreja tendencialmente hostil a Bizâncio, pelo desenvolvimento de uma aristocracia fundiária independente de Constantinopla e por uma revolução urbana que produzia milícias citadinas que só eram fiéis aos seus chefes locais (Ravegnani 2006 75). Ainda assim, percebe-se que, com medo do expansionismo lombardo, a Igreja de Roma foi adiando a rutura com Bizâncio (o papa Constantino, 708-715, chegou a visitar Constantinopla); todavia, o definhamento do exarcado de Itália obrigaria Roma, a breve trecho, a procurar no reino dos Francos um outro (e muito poderoso) aliado.

Pouco há a dizer sobre os imperadores que se seguiram ao fim da dinastia heracliana. Filipico Bardanés (711-713) governou apenas dois anos e opôs-se às decisões do VI Concílio Ecuménico, defendendo o retorno ao monotelismo, para indignação de Roma. Os Árabes atacaram na Ásia Menor e o khan búlgaro, Tervel, chegou a aparecer em Constantinopla, sob pretexto de vingar Justiniano II. Em junho de 713, Filipico foi deposto e cegado, tendo sido colocado no trono um funcionário civil, que escolheu o nome 
de Anastácio II (713-715). Também este teve vida efémera: restabeleceu as relações com Roma e retomou a luta contra os Árabes, mas foi deposto por uma revolta das tropas do tema do Opsíkion, em 715. Subiu então ao poder, durante dois anos, Teodósio III, um antigo cobrador de impostos, mas em 717 foi a vez de o tema dos Anatólicos encerrar o basileús num mosteiro e proclamar como novo imperador Leão III, conhecido como "o Isauriano" (apesar de ser originário, não da Isáuria, mas de Germaniceia, na Síria).

Iniciava-se assim uma nova dinastia, dita "isauriana", que se prolongaria até 802. O Império recuperou alguma estabilidade, tanto mais que Leão III (717-741) era um governante muito enérgico e empenhado em afirmar a autoridade central. O seu longo reinado ficou assinalado por três grandes marcos: i) as vitórias sobre os Árabes; ii) uma nova compilação jurídica; iii) a controvérsia iconoclástica.

Logo em 717-718, o basileús viu a sua posição reconfortada, ao vencer o cerco muçulmano à capital (com 80000 homens e uma frota de 1800 navios, sob o comando do irmão do califa, Maslam). Foi uma grande vitória bizantina, de novo auxiliada pelo uso do fogo greguês, e que seria confirmada em 740, na batalha de Acroino, na Ásia Menor. O império podia agora respirar de alívio, pelo menos na frente oriental.

Em 726, surgiu uma nova compilação jurídica bizantina: o Eklogé (isto é, seleção de leis); tratava-se de uma escolha das leis mais importantes do Codex de Justiniano, mas agora redigidas em grego e adaptadas (p. ex.: ao nível das molduras penais, a mutilação substituía muitas vezes a pena de morte).

No mesmo ano, Leão III emitiu um édito contra a veneração de imagens; o debate não era novo, mas foi avivado por um cataclismo ocorrido na ilha vulcânica de Santorino (no sul do mar Egeu), uma catástrofe que o imperador (porventura sob a influência da iconoclastia dos Árabes, que eram contra a representação de seres 
vivos) terá interpretado como um sinal da ira divina. O debate entre os iconoclastas (os adversários das imagens) e os iconodúlios (os partidários das imagens) assumiu uma relevância extraordinária, pois as imagens estavam associadas à liturgia e eram objeto de uma grande veneração e até de prostração, à maneira pagã, com juramentos, queima de incenso, derrama de pó das imagens em cálices e outros (Ravegnani 2006 78-80). Mas claro que também havia motivações políticas e militares muito pragmáticas por trás deste debate, dada a intervenção ativa dos monges (que eram fortes defensores do culto das imagens), dada a necessidade de seduzir as comunidades da parte oriental do império (onde grassavam as seitas monofisitas e a influência muçulmana) e dada até a reação de alguns dos témata (p. ex., o da Hélade revoltou-se contra o iconoclasmo e nomeou um anti-imperador, tendo organizado uma frota, que seria destruída em Constantinopla).

O debate atingiu também grande expressão em Itália, conduzindo a uma revolta das milícias do exarcado (inicialmente, com o apoio do papa Gregório II) e, em 728, ao assassinato do exarco de Ravenna, Paulo; a frota bizantina da Sicília tentou vingar o ato dos rebeldes, mas foi derrotada pela população de Ravenna, cabendo ao novo exarco, Eutímio, repor mais tarde a situação. Leão III ainda tentou ganhar o papa e o patriarca de Constantinopla, Germano, para a causa iconoclasta, mas não teve sucesso e a fratura alastrou perigosamente: Germano foi substituído por Anastácio e o iconoclasmo tornou-se doutrina oficial do Estado, com perseguições ferozes aos iconodúlios, em especial aos monges. Em Roma, o novo papa, Gregório III, reuniu um concílio que condenou a doutrina iconoclasta, mas, como de costume, as represálias imperiais não se fizeram esperar, com o confisco dos bens papais na Calábria e na Sicília e com muitas igrejas italianas a serem subtraídas à jurisdição romana. Neste cenário, a queda do exarcado de Ravenna tornava-se uma probabilidade cada vez maior! 
Os iconoclastas eram contra a veneração das imagens de Cristo, da Virgem e dos santos; já os iconodúlios eram a favor, alegando que se tratava apenas de símbolos, tal como sucedia com as imagens imperiais. Como explica Jean-Claude Cheynet, o centro do debate estava na legitimidade da representação de Cristo através de uma imagem: "Cristo unia de forma indissociável as duas naturezas, a divina e a humana; ora, o divino não poderia deixar encerrar-se num desenho" (Cheynet 2001 113). Os iconoclastas faziam aos seus adversários uma pergunta embaraçosa: "se eles representavam simultaneamente as duas naturezas, confundindo-as para exprimir o Cristo-Homem, então tornavam-se, dessa forma, monofisitas. Se, pelo contrário, representavam apenas a natureza humana, separando-a da outra, nesse caso tornavam-se culpados de nestorianismo. Tais acusações assentavam na ideia, de raiz platónica, segundo a qual a imagem é da mesma natureza que o seu protótipo" (idem 114). Note-se, entretanto, que os iconoclastas não questionavam o papel da Virgem ou dos santos, mas sim o culto das relíquias; queriam, acima de tudo, travar os excessos e preservar a tradição; segundo eles, as únicas três coisas a venerar eram: a Eucaristia (dada por Cristo e consagrada pelo clero), a Igreja (consagrada pelo bispo) e o sinal da Cruz (oferecida aos homens por Deus, desde Constantino); quanto aos ícones, não tinham lugar em nenhuma destas categorias.

Pelo seu lado, a argumentação dos iconodúlios pressupunha a elaboração de uma teoria da imagem: eles "não podiam limitar-se a afirmar, erradamente, que se pintavam imagens desde o tempo de Cristo, ou mesmo, como recordava João Damasceno, que a Encarnação, ao tornar Deus visível aos homens, tinha abolido a interdição, inscrita na Bíblia, de representar Deus. Era preciso elaborar uma teologia da imagem. Os iconodúlios avançaram então com um argumento decisivo, segundo o qual a imagem não poderia ser da mesma natureza que o protótipo. Em consequência, 
a imagem é relativa e refere-se a um modelo de que não pode partilhar a substância, o que refutava a acusação de idolatria. A imagem de Cristo não se confunde com a essência de Cristo; ela remete, simplesmente, para a humanidade do Filho e permite exprimir o mistério da Encarnação. A imagem é, portanto, muito mais do que um simples instrumento de educação dos fiéis, ela é indispensável ao verdadeiro cristão" (Cheynet 2001 114).

Há quem defenda que o iconoclasmo se afirmou sobretudo na Ásia Menor, mas não parece ter existido uma fronteira geográfica precisa nesta matéria. Certo é que os imperadores iconoclastas constituíram um verdadeiro partido dentro da Igreja (p. ex., nomeando bispos favoráveis para as sés vacantes) e até no exército (p. ex., formando um tágma de elite, com homens escolhidos de entre todos os témata). Uma parte significativa da velha aristocracia da capital opôs-se como pôde a esta política, refugiando-se nas suas terras e fundando mosteiros, que foram autênticos bastiões da resistência da iconodulia.

O imperador que sucedeu a Leão III, Constantino V (741-775), dito "o Coprónimo" (por ter sujado a pia sagrada no momento do batismo), era um iconoclasta convicto. Assim, a controvérsia sobre as imagens acentuou-se (levando o cunhado Artavasde a revoltar-se, até 743), mas o novo basileús também obteve sucessos militares importantes contra os Árabes (no norte da Síria, na Arménia, na Mesopotâmia e ao largo de Chipre), tirando partido da crise interna do califado, mergulhado numa luta sangrenta entre os Omíadas e os Abássidas (um grupo de orientação sunita, que triunfou e transferiu a capital para Bagdade); também nos Balcãs, fez incursões vitoriosas, especialmente na Trácia, entre 772 e 775. No entanto, o principado de Constantino $\mathrm{V}$ ficou manchado pela queda de Ravenna às mãos dos Lombardos, em 751 (precisamente o ano em que Pepino, "o Breve", assumiu o trono dos Francos e deu início à portentosa dinastia dos Carolíngios). Caía, assim, 
o exarcado italiano, o que pôs fim ao domínio bizantino sobre grande parte da Itália do norte e do centro, com exceção de Veneza (que se autonomizaria depois) e, durante alguns anos, da Ístria (que oscilaria entre as mãos de Bizâncio, dos Lombardos e, por fim, de Carlos Magno). Perante as investidas dos reis lombardos Liutprando e Astolfo, restaram a Bizâncio, no sul de Itália, a Sicília, Nápoles, Amalfi, Gaeta e Sorrento (que depois também se autonomizou), enquanto o ducado de Roma passou para as mãos do papa pouco depois de 751, em resultado do apoio dos Francos e dando origem ao embrião do atual Estado do Vaticano.

Constantino $\mathrm{V}$ foi um homem de grande cultura e um teólogo radical, tendo escrito treze tratados religiosos em que negava o dogma da intercessão da Virgem e dos santos, assim como o culto das relíquias, e até de Maria. Em 754, num concílio (pouco ecuménico) reunido em Hieria, no Bósforo (conhecido como "sínodo acéfalo", por não contar com nenhuma delegação papal, nem dos patriarcas do Oriente), os 338 bispos presentes condenaram o fabrico, a posse e a veneração de imagens ou ícones. Esta decisão fez com que a luta contra a iconodulia se radicalizasse, com os mosteiros e os monges a serem alvo de perseguições sistemáticas; por exemplo, o abade Estêvão, de monte Auxentios, junto a Calcedónia, foi linchado por ordem do imperador; também o estratego do tema da Trácia, Miguel Lacanodracone, foi intimado a escolher entre abandonar o hábito de monge (que tinha decidido vestir) ou ser cego e exilado (Ravegnani 2006 83)...

Com a chegada ao poder de Leão IV (775-780), filho do anterior basileús, a repressão atenuou-se, mas o novo imperador morreu muito cedo, deixando o trono a um menino de 10 anos, Constantino VI (780-797), e, sobretudo, à viúva Irene, uma ateniense que era uma iconodúlia convicta. No VII Concílio Ecuménico (o último reconhecido pela Igreja do Oriente), reunido em Niceia no ano de 787, com a presença de delegados do papa e dos patriarcas orientais, 
a heresia iconoclasta foi condenada e os escritos que a sustentavam foram destruídos, o que causa hoje muitas dificuldades de reconstituição de toda esta trama aos historiadores; o culto das imagens foi restaurado e foi assegurada a reintegração dos bispos que se retratassem. Foi, claro está, uma grande vitória do monaquismo.

O governo de Irene ficou assinalado por um ato muito cruel, cometido em 797, e que consistiu na deposição do seu próprio filho, a quem foram arrancados os dois olhos. As derrotas sofridas por Constantino VI diante dos Árabes e dos Búlgaros, acarretando o pagamento de tributos humilhantes, e a chamada "disputa moiqueânica" (resultante da decisão do imperador de repudiar a sua mulher, Maria da Paflagónia, para casar com a amante, cometendo assim adultério: moicheia) parecem ter estado por detrás dessa decisão terrível, que permitiu a Irene governar como soberana única entre 797 e 802. Tratava-se de uma situação inédita em Bizâncio, de tal forma que a imperatriz optou por intitular-se de basileús, evitando o uso da forma no feminino (basílissa)... Uma mulher no poder não deu, porém, sorte alguma a Bizâncio, pois ela conduziu uma política financeira ruinosa (favorecendo descaradamente os mosteiros), o que levou a um golpe palaciano chefiado pelo logóteta das finanças, Nicéforo I (802-811); foi encerrada num mosteiro, em Lesbos, onde morreu logo em 803. Curiosamente, pouco antes destes acontecimentos, chegara a Constantinopla uma delegação franca para propor o casamento de Irene com Carlos Magno, unificando assim o Ocidente e o Oriente; Nicéforo I, que não reconhecia a autoridade do imperador carolíngio, mandou os embaixadores embora (Ravegnani 2006 85)...

Por esta época, acendeu-se uma disputa grave entre Francos e Bizantinos, em torno da posse de Veneza, uma cidade cada vez mais autónoma e onde existia um forte partido pró-franco. Depois de algumas operações militares, terrestres e navais, foi selado um acordo entre as cortes de Constantinopla e de Aix-la-Chapelle. 
Nicéforo I não teve, portanto, vida fácil, sendo obrigado a reorganizar a política fiscal - o que suscitou a ira dos monges -, a reprimir uma revolta dos Eslavos no Peloponeso (em 805) e a formar novos témata. Porém, foi contra os Búlgaros (muito reforçados desde que Carlos Magno destruíra os Ávaros) que sofreu os principais reveses, em especial ao ser derrotado nas montanhas balcânicas, em julho de 811. Nicéforo I morreu nesse combate, e o khan Krum, que já invadira o império dois anos antes, deu-se ao requinte de fabricar uma taça com o crânio do basileús... O filho do infeliz imperador, Stauracio (811), ainda chegou a ser proclamado, mas, devido aos ferimentos que sofrera na mesma guerra, não teve condições para governar e acabou encerrado num mosteiro pelo cunhado, o kouropalátēs Miguel I Rangabé (811-813).

Ocorreram então importantes negociações entre as potências franca e bizantina, que conduziram à assinatura do Tratado de Aquisgrana (Aix-la-Chapelle), em 812. Bizâncio reconheceu a Carlos Magno (que morreria dois anos mais tarde) o título de "imperador", mas não "dos Romanos", prerrogativa que muito simbolicamente reservou para o seu próprio basileús. Ficou também assegurado o domínio franco sobre a Ístria e a Dalmácia (salvo nas cidades costeiras), enquanto Veneza reentrava na órbita de Constantinopla.

No ano seguinte, Miguel I foi derrotado pelos Búlgaros em Versinika (perto de Adrianopla), provavelmente devido a uma traição do estratego do tema da Anatólia, Leão, "o Arménio", que, na sequência deste desastre, subiu ao trono como Leão V (813820), dando início ao chamado "segundo período iconoclasta". O começo do reinado de "o Arménio" ficou marcado por novos ataques búlgaros a Constantinopla, em especial com o cerco de 814, interrompido pela morte de Krum, circunstância que permitiu a assinatura de uma paz de trinta anos entre Bizâncio e a Bulgária. No plano religioso, Leão $\mathrm{V}$, um iconoclasta da mesma escola militar de Leão III, "o Isauriano", anulou as decisões de Niceia - 787 (no 
Sínodo de Santa Sofia, em 815, onde também se repôs Hieria - 754), submeteu a Igreja, exilou muitos monges e depôs o patriarca de Constantinopla, Nicéforo (autor de uma importante obra literária e histórica, em especial a Síntese Cronográfica, desde Adão até 829, e o Breviário ou História Abreviada, preciosa para conhecer Bizâncio entre 602 e 769), substituindo-o por um parente afastado de Constantino V, chamado Teodoto Melisseno.

A rutura não trouxe sorte a Leão $\mathrm{V}$, que em 820 foi assassinado por um dos seus mais próximos camaradas de armas, Miguel II, "o Amoriano" (nascido em Amório, na Frígia). Com este novo imperador, iniciou-se uma derradeira (e muito curta) dinastia antes do surgimento (em 867) dos grandes imperadores macedónios. Miguel II (820-829) teve de suportar o cerco de Tomás, "o Eslavo", a Constantinopla (em 823, com o apoio do califa abássida) e tentou, em vão, responder aos avanços árabes, que aos poucos tomaram conta da ilha da Sicília (conquistaram Palermo em 831 e Siracusa em 878, com uma grande carnificina). Sucedeu-lhe o filho Teófilo (829-842), homem de uma certa erudição e admirador da cultura islâmica, que retomou a política iconoclástica com grande energia, contando com o apoio do patriarca João Gramático (uma das figuras representativas do renascimento cultural do século Ix); porém, a resistência monástica mostrou-se tenaz, e a ambicionada restauração iconoclástica, iniciada por Leão $\mathrm{V}$, acabou por não surtir efeito. À morte de Teófilo, subiu ao trono Miguel III (842-867), que substituiu João Gramático pelo ortodoxo Metódio e que promoveu a restauração do culto das imagens no Sínodo de 843. Ao que parece, a reviravolta foi patrocinada pela viúva de Teófilo, Teodora, regente em nome do seu filho menor: foi o fim do iconoclasmo e o início da Festa da Ortodoxia, assinalada, até aos dias de hoje, no primeiro domingo da Quaresma. Embora em Bizâncio a subordinação religiosa ao poder político fosse uma idiossincrasia, nesta altura a Igreja ortodoxa pôde respirar um 
pouco mais fundo e ter-se-á então sentido mais liberta da tutela imperial (Ravegnani 2006 89-90).

Miguel III ficou com fama de devasso, mas protagonizou um reinado bastante bem-sucedido, inicialmente sob a tutela da mãe e de alguns conselheiros: conseguiu obter sucessos importantes na Ásia Menor, contra os Árabes, a partir de 863, através de uma estratégia ofensiva pouco comum em Bizâncio e que recorda a época de Heráclio. Convém, no entanto, lembrar que, por esta altura, a expansão muçulmana estava em clara recessão, com as rivalidades entre os Abássidas de Bagdade e os Omíadas estabelecidos na Hispânia a partir dos meados do século VIII, com o fracasso das ambições na Gália (as célebres derrotas diante de Carlos Martel) e com a constituição do califado fatímida do Egito, de orientação xiita e rival de Bagdade.

Em 856, Miguel III encerrou a mãe, Teodora, num mosteiro e passou a uma fase de poder absoluto, embora o seu tio Barda (feito kâ̂sar em 862) tivesse um papel determinante na governação. Foi também uma época de algum renascimento cultural (há quem fale de um "primeiro humanismo bizantino"), que contrasta com o obscurantismo iconoclástico, tendo-se dado a reabilitação da chamada "Universidade de Constantinopla", com a conversão do palácio imperial da Magnaura em centro da cultura profana; grandes mestres, como Leão, "o Matemático", que redescobriu a ciência euclidiana e que o próprio califa abássida Al Mamum cobiçou, ensinaram neste novo espaço, que acolhia todos os saberes. Sublinhe-se também a eleição de Fócio (ou Phốtios, c. 810-c. 893) como patriarca da capital, em 858, um laico que fora chanceler e que Barda, em rutura com o patriarca Inácio, promovera; é autor de uma obra monumental, a Biblioteca, em que resumiu nada menos do que 279 obras religiosas e profanas, clássicas e bizantinas, que tinha lido! Fócio interessou-se pelos autores pagãos, apesar de ter dado preferência aos cristãos, e as suas notas testemunham 
um método de crítica textual muito interessante, oferecendo-nos simultaneamente uma panorâmica das obras que no seu tempo se podiam encontrar em Constantinopla; convém também frisar que, no Eisagōgế, este príncipe dos patriarcas medievais estabeleceu um pouco à maneira da célebre teoria dos dois gládios expressa pelo papa Gelásio I, em finais do século V - um paralelismo entre as funções temporal e espiritual, tendo definido o imperador como uma autoridade legítima submetida não apenas aos cânones da Igreja mas também às leis dos seus predecessores; quanto ao patriarca, via-o como "a imagem viva e animada do Cristo" e um concorrente do basileús (tradicionalmente apelidado, como já vimos, de "imitador de Cristo", sobretudo a partir de Justiniano), uma formulação que jamais foi verdadeiramente aceite pelos imperadores (Cheynet 2001 23). Claro que Roma se opôs a esta eleição, e o papa Nicolau I (858-867) tratou de depor o patriarca Fócio, mas depois foi ele próprio excomungado pelo Senado de Constantinopla, em 867, numa reunião em que a Igreja romana também foi acusada de heresia e onde se condenou a sua ingerência nos assuntos da Igreja bizantina; apenas a morte de Miguel III (em 867) evitaria um novo cisma.

Convém também recordar a grande atividade missionária de Miguel III na Morávia (um Estado eslavo entre a Boémia e a Eslováquia) e na Bulgária; tal como os primeiros Carolíngios gostavam de fazer no Ocidente, o último dos Amorianos entendia que a dominação militar deveria ser completada com a evangelização do território: foi justamente neste contexto que teve lugar a importantíssima missão de dois irmãos de Tessalónica, Cirilo (ou Constantino) e Metódio, na Morávia, da qual veio a resultar a criação do alfabeto glagolítico (do verbo glagolati, que significa falar), usado em manuscritos eslavos antes do desenvolvimento do alfabeto "cirílico", derivado do alfabeto grego mas com elementos dos alfabetos copta e hebraico. Como se sabe, este alfabeto 
cirílico continua hoje a ser utilizado em diversas línguas eslavas; acrescente-se que, graças à escrita glagolítica, Cirilo e Metódio traduziram as Sagradas Escrituras para o antigo eslavo. O czar búlgaro foi batizado em 804 , e a sua Igreja, que inicialmente se aproximou dos Francos e, depois, do papa, acabaria por se submeter a Constantinopla, embora o respetivo arcebispo conservasse uma certa autonomia (Ravegnani 2006 94).

Em 867, Miguel III foi assassinado durante o sono pelo seu próprio favorito e coimperador, Basílio, "o Macedónio", que já eliminara o rival Barda dois anos antes. Era o início da dinastia macedónica, que duraria quase dois séculos e que é, provavelmente, a mais brilhante de toda a história bizantina.

Basílio I (867-886) era um homem de origem modesta, da região de Adrianopla, que beneficiara de um casamento proveitoso com uma viúva do Peloponeso. Graças à sua força hercúlea, tornara-se escudeiro de Miguel III e, em 865, recebera um alto cargo palatino; no mesmo ano, eliminara Barda e tornara-se coimperador. Em pouco tempo, a relação entre Miguel III e Basílio degradou-se e levou ao assassinato do basileús. Basílio I tratou de repor o patriarca Inácio, afastando Fócio e reatando as relações com Roma (papa Adriano II); em 869-870, o Concílio de Constantinopla excomungou Fócio, que foi exilado, mas o notável letrado seria mais tarde reintegrado como patriarca, com o apoio do papa João VIII e de um sínodo reunido em 879, dois anos após a morte de Inácio.

Ao nível da política externa, Basílio I reforçou a posição bizantina na Dalmácia, onde constituiu um novo tema e fez abortar o ataque muçulmano de 867 a Ragusa (Dubrovnik). O novo imperador conseguiu também sucessos importantes no Oriente, contra os Árabes (e contra a seita herética dos Paulinianos). Mas foi no sul da Itália que a estrelinha de Basílio I mais brilhou, com reconquistas 
notáveis na Apúlia (caso de Bari, em 871, com o apoio de Luís II, imperador franco), na Lucânia e na Calábria (tomada de Tarento, em 880, com forte investimento naval); em 876, Bari tornar-se-ia a capital da Itália bizantina. Esta cavalgada surpreendente seria consolidada por um grande militar, o estratego Nicéforo Focas, que eliminou a presença árabe na Calábria e estendeu em profundidade a influência imperial em Itália (Ravegnani 2006 96).

Em 886, durante uma caçada, Basílio I encontrou a morte e foi rendido no trono pelo seu filho, Leão VI, “o Sábio” (886-912). Recai sobre este novo imperador - homem letrado, poeta e profeta místico, mas que tinha com Basílio I uma relação muito difícil - a suspeita de ser realmente filho de Miguel III, a quem dispensou grandes honras fúnebres. No plano militar, Leão VI (que escreveu um importante tratado de arte da guerra, Taktika: Dennis 2014) obteve alguns sucessos no Oriente e na Itália do sul, onde conseguiu ocupar durante algum tempo a Benevento lombarda, ao mesmo tempo que impedia os Árabes de se fixarem na Calábria. Contudo, noutras paragens, foram grandes os reveses sofridos pelo "Sábio", com os Árabes a tomarem Tessalónica, a frota bizantina a ser derrotada em Kios, em 912, e, sobretudo, com o czar búlgaro Simeão a revoltar-se e a atacar; Leão VI, seguindo uma velha orientação estratégica romana, aliou-se aos Húngaros para melhor se defender, mas Simeão, pelo seu lado, coligou-se com os Petchénègues e obteve uma vitória decisiva em Bulgarophigon (na Trácia, atual Bulgária), em 896, obrigando o império a uma paz difícil e a mais um tributo pesado.

Foi também no tempo de Leão VI que foram promulgadas as Basiliká, uma nova compilação jurídica, iniciada pelo seu antecessor: trata-se de 60 livros de recolha de leis, completada por muitas leis novas (as Novelle); como comenta Ravegnani (2006 98), foi uma importante reelaboração do direito justiniano, numa recolha muito mais sistemática e toda ela em língua grega, que 
estabeleceria as bases do sistema jurídico bizantino para as centúrias seguintes.

O final do principado de Leão VI foi marcado por uma violenta polémica com a Igreja, por causa do quarto casamento do imperador, que desejava a todo o custo garantir um herdeiro varão. As três primeiras mulheres do basileús (Teófane, Zoé Zautzina, de quem teve uma filha, e Eudóxia Bainé, que morreu no parto de um menino que faleceria poucos dias depois) estavam todas mortas, e o basileús decidiu casar pela quarta vez, com a sua amante Zoé Carbonopsina. Porém, o patriarca de Constantinopla, Nicolau Místico, opôs-se veementemente, e o matrimónio foi celebrado por um padre do Grande Palácio, de modo a legitimar-se o filho do casal, o futuro Constantino VII Porfirogeneta. O patriarca, na linha da doutrina de Fócio, alegava que o imperador estava obrigado a respeitar as leis e lembrava que, nas Novelle, Leão VI vetara os terceiros casamentos e até desaprovara os segundos... A disputa assumiu uma enorme gravidade, com Nicolau Místico a impedir o imperador de participar em algumas cerimónias religiosas em Santa Sofia (p. ex., no Natal de 906 e na Epifania do ano seguinte). Porém, Leão VI conseguiu obter uma bula de dispensa papal para este seu último casamento e aproveitou para substituir Nicolau Místico por Eutímio no patriarcado de Constantinopla.

Quando "o Sábio" faleceu, Constantino VII (913/944-959) era ainda um menino, pelo que a regência ficou à guarda do tio Alexandre, que todavia morreu logo em 913, sem tempo para mais do que repor Nicolau Místico e expulsar Zoé do Grande Palácio. Esta situação gerou um vazio de poder, que deu lugar a uma terrível luta de fações: de um lado, o patriarca reposto, apoiado pelo conselho de regência; do outro, a regressada Zoé, a que se juntava o partido eclesiástico fiel a Eutímio. Neste ambiente, o domestikós dos scholaí, Constantino Ducas, tentou conquistar o poder, mas o golpe foi brutalmente reprimido pelo patriarca Nicolau. 
Quem aproveitou toda esta disputa foi o czar Simeão, que, alegando o não pagamento do tributo devido aos Búlgaros, atacou Constantinopla, com o sonho de formar um grande império búlgaro-bizantino de que seria ele o titular, tanto mais que fora formado no ambiente cultural bizantino. Constantinopla teve de negociar: pagou, prometeu a mão de Constantino VII a uma filha de Simeão e o patriarca ainda coroou o czar como basileús dos Búlgaros, que se retiraram satisfeitos. Porém, em 914, Zoé protagonizou um golpe na capital e rejeitou o acordo, o que levou Simeão a atacar de novo o território bizantino, obtendo duas vitórias importantes em batalha campal. Em 924, o czar búlgaro cercou outra vez Constantinopla, mas as muralhas e a diplomacia bizantina (que frustrou um acordo dos Búlgaros com o califado fatímida do Egito) neutralizaram a ofensiva. Simeão foi obrigado a negociar com Romano Lecapeno, o droungários (chefe da frota) que, em 919, se tinha imposto em Constantinopla, tornando-se regente em vez de Zoé. O czar sonhador morreria em 927, seguindo-se um acordo entre Bizâncio e o novo líder dos Búlgaros, que obteve algum reconhecimento e a mão de Maria, a neta do coimperador Romano Lecapeno (ou Romano I).

Como já se percebeu, Romano I (920-944) foi o primeiro dos usurpadores da era macedónica, que atuaram contudo de uma forma cautelosa: mantiveram sempre no trono o soberano legítimo, desse modo mostrando a sua lealdade à dinastia no poder (um princípio que ia ganhando raízes cada vez mais fundas na tradição política bizantina). Apesar disso, sendo coimperador desde 920, Romano Lecapeno (o nome vem de Lakape, na Arménia, onde nascera) promoveu o casamento de Constantino VII com a sua filha Helena, o que o tornava basileopátōr (pai do imperador), relegando Constantino VII para terceiro lugar na linha sucessória (a seguir a ele próprio e ao seu filho mais velho, Cristóvão, o pai de Maria)... Mais tarde, Romano I tornou-se kâ̂sar e imperador associado. 
Consolidado no poder, Romano I procurou sarar as feridas, fazendo a paz com os Búlgaros e aproveitando o Sínodo de 920, em Constantinopla (com a presença de legados papais), para promulgar o "Tomo da União", onde se reprovava o quarto casamento de Leão VI mas se absolvia este imperador e se legitimava o filho Constantino VII e o patriarca Eutímio, sem pôr em causa a figura de Nicolau Místico, o que permitiu a reconciliação das duas Igrejas. O resto do longo período de governação de Romano I ficou assinalado por três marcos essenciais.

Em primeiro lugar, a contenção do expansionismo da nação russa, que se constituíra no século Ix, através da integração da componente eslavo-oriental que se fixara nas planícies do Volga e da componente constituída por Vikings suecos (ou Varegues) que conquistaram a região (o próprio nome "Russos" provém de uma tribo viking da parte europeia da atual Rússia, com capital em Kiev); em 941, os Russos saquearam a parte asiática do Bósforo, mas o basileús derrotou-os no mar; dois anos mais tarde, o príncipe Igor tentou atacar os Balcãs, mas Romano I antecipou-se e negociou a paz.

Em segundo lugar, a obtenção de algumas vitórias espetaculares sobre os Árabes, nomeadamente a destruição da esquadra de Leão de Trípoli (perto de Lemno, em 924), a reconquista de Melitena (na Arménia, em 934) e as operações contra o emir de Mossul e de Alepo (Sayf al-Dawlah), na Síria, com recuperação da famosa relíquia mantélion de Edessa, uma peça de tecido com a imagem de Cristo, que se dizia ter sido feita por mão não humana.

Em terceiro lugar, a produção de uma série de leis de proteção da pequena propriedade camponesa e de contenção da expansão dos latifúndios, incluindo a reposição, em 922, da lei do protímēsis, que concedia prioridade na aquisição de terra alienada aos vizinhos e parentes do antigo proprietário (alargando-se o princípio, no caso dos bens dos soldados, aos últimos trinta anos); apesar 
de reforçada por volta de 934, a medida não resultou, não só por causa da carestia mas sobretudo porque a sua aplicação concreta foi sabotada pelos funcionários que deveriam vigiar a sua entrada em vigor e pelos latifundiários.

Em 944, os filhos de Romano I revoltaram-se e afastaram-no do poder, mas a população de Constantinopla, numa ação claramente legitimista, insurgiu-se contra qualquer projeto de interrupção da dinastia macedónica e devolveu o trono ao monarca que no fundo estivera cerca de duas décadas afastado do poder real, Constantino VII Porfirogeneta (isto é, nascido na Porphýra, uma câmara do palácio com as paredes forradas a pórfiro, doravante um sinal da legitimidade dinástica), que foi sobretudo um homem de cultura, a quem se deve uma atividade notável como mecenas, como pintor, como mandante de obras eruditas (sobretudo literatura enciclopédica) e ainda como autor: escreveu o Livro das Cerimónias (c. 938-959), onde se analisa a etiqueta da corte e as cerimónias religiosas e profanas, com descrições minuciosas que têm ajudado sobremaneira a reconstituir a fisionomia e a organização interna do Grande Palácio) ${ }^{4}$; e foi ainda o autor da Vida de Basílio I (seu avô), do Livro dos Témata (um tratado histórico-geográfico sobre as províncias bizantinas) e do escrito Sobre a administração do Império (um tratado dedicado ao filho, Romano II, e versando a arte de bem governar, à maneira dos célebres "espelhos de príncipes" ocidentais). No plano político-militar e diplomático, registem-se

\footnotetext{
4 Outra obra da mesma época, ligeiramente anterior (c. 899) e que trata também o cerimonial da corte (banquetes, etiqueta, etc.) é o Kletorológion, de Filoteu. Este escrito, destinado a orientar os funcionários palatinos responsáveis pelo protocolo, fornece grandes indicações sobre a hierarquia e o aparelho burocrático coevos. Por aqui se percebe que os cortesãos estavam divididos em duas categorias: os dignitários da corte, que recebiam uma "dignidade por meio de sinais", honorífica e vitalícia, materializada numa insígnia ou numa patente; e os titulares de cargos temporais, a quem era atribuída uma "dignidade por voz" ou por édito, revogável. Em ambos os casos, separavam-se as dignidades dos eunucos das dignidades próprias dos "homens barbudos". Voltaremos a este assunto mais adiante.
} 
sobretudo as novas vitórias obtidas sobre os Árabes, na Anatólia e no Eufrates, através de notáveis generais como Nicéforo Focas ou João Zimisce, assim como a visita (em 957) da princesa Olga de Kiev a Bizâncio, onde se demorou bastante tempo e onde se converteu ao cristianismo. Poucos anos antes (em 949), tinha estado também em Constantinopla (como embaixador de Berengário II, marquês de Ivreia e futuro rei de Itália) Liutprando de Cremona, que nos deixou no Antapódosis um relato maravilhoso da sua experiência (de alguns meses) na corte bizantina, que trataremos de aproveitar um pouco mais adiante. Em termos de política agrária, Constantino VII manteve-se fiel à linha orientadora definida pelo seu pai.

Em 959, Romano II (959-963) sucedeu ao autor do Livro das Cerimónias. Tinha 21 anos de idade e parece ter sido um homem bastante dado ao luxo e aos prazeres, frívolo e sibarita (Ravegnani 2006 108). Pouco interessado na arte de governar (apesar do manual que o pai compilara para ele), casou em segundas núpcias ${ }^{5}$ com a filha de um estalajadeiro, Teófane, de quem teve dois filhos: Basílio (o futuro Basílio II) e Constantino (o futuro Constantino VIII). Em 963, à morte prematura de Romano II, a viúva ocupou a regência, tendo acabado por estabelecer um acordo com o general Nicéforo Focas, que se apoderou do trono na sequência de uma sublevação militar e com quem Teófane acabou por casar, legitimando-o como coimperador, sob o nome de Nicéforo II Focas (963-969). O grande general, expoente da aristocracia militar e autor eventual de um grande tratado de arte bélica (De Velitatione, um tratado sobre a guerrilha: Dennis 1985), governou como tutor de Basílio II. Tinha a seu favor uma carreira brilhante, pois reconquistara a ilha de Creta e obtivera diversos sucessos na Ásia Menor, como

\footnotetext{
5 O primeiro casamento de Romano II foi com Berta, filha natural de Hugo da Provença, um matrimónio que fora considerado degradante em Bizâncio, onde, como veremos, imperava a tradição de os imperadores desposarem mulheres bizantinas.
} 
já dissemos. Em matéria de política agrária, favoreceu, porém, os latifundiários, anulando as medidas dos seus antecessores sobre a proteção da pequena propriedade camponesa. Embora bastante religioso, esforçou-se por conter o crescimento da população eclesiástica, em especial dos mosteiros, por considerar que isso era uma ameaça.

No que diz respeito à parte militar, Nicéforo II distinguiu-se pela anexação da Cilícia, de Chipre e de uma grande parte da Síria (incluindo Antioquia), em detrimento dos Árabes; no sul de Itália, reforçou a presença bizantina, apesar da oposição de Otão I, o titular do Sacro Império Romano-Germânico. Este poderoso monarca (que em 955 travara a expansão magiar para o Ocidente, na célebre batalha de Lechfeld) surgiu em 966 em Itália, disposto a expulsar os Bizantinos da Apúlia e da Calábria; começou por utilizar a via diplomática, propondo o casamento do seu herdeiro, Otão II, com uma irmã de Basílio, mas Nicéforo II recusou e Otão atacou Bari, sem sucesso. Dois anos mais tarde, enviaria uma embaixada a Constantinopla (curiosamente, chefiada por Liutprando de Cremona), insistindo no projeto matrimonial, mas o coimperador recusou de novo. Assim, em finais de 968, Otão I devastou o território bizantino em Itália, embora sem conseguir conquistar as principais cidades e sem evitar que os Bizantinos capturassem o seu principal aliado, o príncipe lombardo de Cápua e Benevento, Landolfo. Mas, em finais de 969, Otão I obteve uma vitória muito importante em Ascoli e conseguiu ocupar algumas cidades da Apúlia.

Este revés militar, bem como a política fiscal e autoritária de Nicéforo II Focas, levaram a um golpe palaciano em dezembro de 969: com a ajuda de Teófane, o amante desta e também consagrado general João Zimisce eliminou o coimperador e subiu ao trono. A ideia de Teófane era casar com Zimisce, mas o patriarca Polieucte opôs-se ao sórdido projeto, e o novo coimperador 
(antigo companheiro de armas de Focas) viu-se mesmo obrigado a exilar a amante.

João Zimisce (969-976), no fundo o terceiro usurpador da era macedónica (depois de Romano I Lecapeno e de Nicéforo II Focas), alargou consideravelmente o território do Império Bizantino, conquistando a Palestina aos Árabes e fazendo uma campanha na Bulgária contra o príncipe russo de Kiev, Svyatoslav (que Nicéforo II tinha chamado para travar os Búlgaros, mas que depois decidira estabelecer-se por lá, traindo Bizâncio); esta intervenção do coimperador Zimisce permitiu a anexação da Bulgária oriental, até ao rio Danúbio. Do lado ocidental, foi conseguido um bom acordo com Otão I, que renunciou à disputa pela Itália meridional em troca de um bom casamento (com uma outra Teófane, provável parente de Zimisce). É interessante notar que Otão I tinha (como Carlos Magno o fizera duzentos anos antes) restaurado o título imperial, mas Bizâncio (ainda no tempo de Constantino VII) reagira de novo à ideia e utilizara em seu proveito a célebre Doação de Constantino, um documento falso, forjado nos meios eclesiásticos romanos nos inícios do século Ix, e que dizia que Constantino I, depois de refundar e rebatizar a cidade de Bizâncio, onde se estabeleceu, confiara Roma e a sua região ao Sumo Pontífice (o papa Silvestre); este "falso" serviu à Santa Sé para justificar a existência do Estado pontifical e a independência do seu chefe perante o poder temporal, mas foi também utilizado pelos imperadores bizantinos para mostrar que Constantinopla era a única verdadeira herdeira de Roma, tendo ocorrido uma transferência do poder imperial (translatio imperii), pelo que nenhum outro soberano, além do bizantino, tinha o direito de utilizar o título imperial, muito menos um soberano germânico como Otão I...

Em 976, com o corpo massacrado por feridas de guerra, João Zimisce fechou os olhos para sempre, deixando à beira do poder os dois filhos legítimos de Romano II e de Teófane, em nome de 
quem governara: Basílio (com 18 anos de idade) e Constantino (com 16 anos). O governo ficou interinamente a cargo do eunuco Basílio (filho bastardo de Romano Lecapeno e o favorito de Focas, por ser um homem bastante capaz), mas Basílio II (963/976-1025) depressa se desembaraçou de todos os rivais e, com extrema energia, arrancaria para um principado brilhante.

Os primeiros tempos foram muito difíceis, com uma revolta da aristocracia fundiária da Ásia Menor (um autêntico viveiro de generais bizantinos) encabeçada por Barda Sclero, um parente de João Zimisce; contudo, o jovem Basílio II apoiou-se no alto aristocrata e chefe militar Barda Focas e, em 979, salvou a situação. Seis anos depois, Basílio II exilou o eunuco seu homónimo e começou a governar sozinho, em seu nome e no do seu irmão Constantino; porém, no cenário búlgaro, a situação complicou-se, pois o czar Samuel conseguira ressuscitar a antiga potência e impôs uma derrota a Bizâncio, que serviu de pretexto para uma nova revolta aristocrática liderada por Sclero (em 987). O imperador enviou de novo Focas, mas desta vez os dois Bardas entenderam-se entre si e combateram juntos Basílio II! Depois, Focas prendeu Sclero e prosseguiu a luta sozinho, colocando o basileús à beira de um colapso; valeu a este a aliança com o príncipe Vladimiro de Kiev e a consequente vitória na batalha de Abido (em abril de 989), onde Barda Focas caiu morto. Sclero ainda se proclamaria imperador, mas Basílio II acabou por estabelecer com ele um bom acordo (no mesmo ano) e a situação serenou. Bizâncio teve foi de recompensar fortemente Vladimiro, que recebeu nada menos do que a mão de Ana Porfirogeneta (a irmã do imperador), algo raro na tradição política bizantina e que até a Otão I havia sido negado! Em contrapartida, Vladimiro converteu-se ao cristianismo, e o facto acarretou a conversão do seu povo; assim, a Rússia entrou na órbita do patriarca de Constantinopla e da cultura bizantina durante séculos; o uso do alfabeto cirílico e o papel da Igreja 
ortodoxa na Rússia, até aos dias de hoje, não são de modo algum alheios a esta história...

Também Basílio II quis proteger os pequenos camponeses, com legislação semelhante à de Romano I Lecapeno e obrigando ainda os magnatas a pagarem uma taxa (o allēléngyon) pelas terras baldias, tornando os proprietários ricos solidários dos contribuintes faltosos da comunidade aldeã, sem por isso os autorizar a retomar a sua terra (Cheynet 2001 93); muitas famílias de aristocratas (como os Focas, os Maleinos ou os Filocales) foram despojadas de quase todos os seus bens, ou detidas (Ravegnani 2006 114). Mas os melhores anos de Basílio II decorreram, sem dúvida, das vitórias que conseguiu obter contra os Búlgaros e que lhe valeram, aliás, o cognome de Boulgaroktónos (o exterminador de Búlgaros)! O imperador comandou pessoalmente uma máquina de guerra formidável, que a partir de 990 atacou a Bulgária durante vários anos; em 1004, o basileús já tinha mais de metade do território búlgaro nas suas mãos, mas prosseguiu a luta durante mais uma década e, em 1014, acabou por cercar e dizimar o exército de Samuel num desfiladeiro: 14000 prisioneiros foram enviados ao czar (que conseguira fugir) em grupos de 100, dos quais 99 cegos e apenas um deles com um dos olhos sãos, para lhes servir de guia; perante este cenário horrendo, diz-se que Samuel perdeu os sentidos, vindo a falecer dois dias mais tarde (Ravegnani 2006 116). Quatro anos depois deste acontecimento, a Bulgária foi definitivamente vencida e anexada ao Império Bizantino. Esta foi a coroa de glória de Basílio II, que também interveio na Síria, em Itália e no Cáucaso, e que, pensa-se, estaria a preparar uma grande expedição para, com a ajuda de Veneza, expulsar os Árabes da Sicília, quando a morte o surpreendeu, dez dias antes do Natal de 1025. Como remata Giorgio Ravegnani, sob o governo do "exterminador de Búlgaros", o Império Bizantino tinha logrado alcançar a sua máxima extensão desde a era de Justiniano, em meados do século vi (2006 116). 
Seguiu-se meio século de crise (entre 1025 e 1081), com a degradação da autoridade central, o crescimento dos latifúndios, a substituição progressiva dos témata pelo recrutamento de mercenários, uma fratura religiosa definitiva com Roma (após o Cisma de 1054) e, sobretudo, com o aumento das ameaças militares externas, devido ao aparecimento na cena político-militar de dois novos (e temíveis) protagonistas: os Turcos Seljúcidas e os Normandos.

A Basílio II sucedeu o seu irmão mais novo, Constantino VIII (1025-1028), com o qual se extinguiu a linha masculina da dinastia macedónica. Não teve tempo para quase nada e, no seu leito de morte, forçou a filha Zoé, já cinquentenária, a casar com o éparchos de Constantinopla, Romano Argiro (que até já era casado). O matrimónio celebrou-se em 1028 e deu início ao período dos chamados três "príncipes consortes" (todos eles maridos desta Zoé, já que a irmã, Teodora, se recusou sempre a aceitar o procedimento). Romano III Argiro (1028-1034) foi o primeiro desses príncipes e praticamente só trouxe más notícias para o grosso da população do império: transferência de terras para os latifundiários, fim do centralismo administrativo macedónico, diminuição dos ingressos fiscais e da mão-de-obra civil e militar, grandes concessões à Igreja e aos mosteiros, retoma dos gastos sumptuosos por parte de uma corte frívola e corrupta (uma intriga levou mesmo Zoé a encerrar a irmã Teodora num mosteiro), entre tantos. O governo real ficou nas mãos de um monge eunuco chamado João Orfanótrofo, natural da Paflagónia (nas margens do mar Negro), que aproveitou a circunstância para abrir o caminho do poder para o seu próprio irmão Miguel, que tratou de ligar sentimentalmente a Zoé, rejeitada pelo marido. Assim, em 1034, Romano III foi assassinado na piscina do Grande Palácio e, no mesmo dia, Zoé casou com Miguel IV, "o Paflagónico" (1034-1041). 
Miguel IV foi um bom governante, mas morreu muito novo e foi sucedido pelo sobrinho Miguel V, “o Calafate” (1041-1042), que Zoé adotara como filho. O novo imperador afastou João Orfanótrofo e substituiu-o por um outro tio seu, chamado Constantino. A seguir, tentou encerrar Zoé num mosteiro, mas, curiosamente, confirmando a sua progressiva afeição à regra do legitimismo dinástico, o povo de Constantinopla revoltou-se, dado que a decisão retiraria de cena a imperatriz, que era o verdadeiro elo entre os novos governantes e a dinastia macedónica! Miguel V foi deposto e nem a aparição in extremis de Zoé na tribuna do Hipódromo, vestida de monja (ao que parece, por esquecimento imperdoável dos cortesãos de “o Calafate”) salvou a situação: o povo pensou que ela estava presa, retirou Teodora do mosteiro e fê-la coroar em Santa Sofia, pelo patriarca. Quanto a Miguel V, fugiu da capital com o seu tio, mas foi capturado numa igreja e foram ambos cruelmente torturados (arrancamento dos olhos, um ato testemunhado e descrito por uma das nossas principais fontes da época: Miguel Pselo).

O poder ficou então nas mãos das duas irmãs, Zoé e Teodora, que se detestavam. Pelos vistos, já se admitia mais facilmente em Bizâncio que uma mulher (ou, neste caso, duas!) pudesse(m) governar o império, e agora por vontade do povo e não por abuso de poder, como sucedera com Irene entre 797 e 802 . Como comentou Miguel Pselo, "foi então a primeira vez que o nosso tempo viu o gineceu transformar-se em Consistório imperial, com os civis e os militares a porem-se de acordo sob a liderança de duas damas e a obedecerem-lhes melhor do que a um qualquer déspota viril" (ed. Signes 2005)... No entanto, a experiência não correu bem, pois as irmãs não se entenderam e os conselheiros decidiram que haveria que casar uma delas; perante a recusa de Teodora, Zoé contraiu matrimónio pela terceira vez, desta feita com um nobre ancião de Constantinopla, que ficou para a história com o nome 
de Constantino IX Monómaco (1042-1055). Foi um reinado relativamente fraco, mas com quatro acontecimentos decisivos:

i) a confirmação do desaparecimento do exército nacional dos témata, substituído por forças mercenárias, talvez com a intenção de conter a aristocracia militar (ainda que, salvo no caso dos estrategos dos témata, fosse muito difícil à oposição mobilizar forças privadas capazes de enfrentar a guarda imperial);

ii) o desenvolvimento incontrolado da grande propriedade agrícola, agravando as condições de vida dos pequenos proprietários e satisfazendo os donos dos latifúndios;

iii) o cisma definitivo entre as Igrejas de Roma e de Constantinopla, em 1054, na sequência dos desentendimentos entre o papa Leão IX (um dos maiores reformadores cluniacenses) e o patriarca Miguel Cerulário, em torno de quatro velhas questões: a dupla procedência do Espírito Santo, o jejum de sábado, o casamento dos padres e o uso de diversos tipos de pão na comunhão. Constantino IX não teve forças para se impor ao patriarca de Constantinopla, mostrando como o tradicional cesaropapismo bizantino entrara já em declínio;

iv) um florescimento cultural assinalável, especialmente em resultado da ação e das obras de Miguel Pselo (apelidado de "cônsul dos filósofos") e João Xifilino (jurista) e também devido ao aparecimento de uma 'universidade' de Filosofia e Direito em Constantinopla, no ano de 1045.

Em relação a este último ponto, vale a pena frisar que Miguel Pselo (um funcionário público que se tornou árbitro da política imperial) foi um dos maiores nomes da cultura bizantina, sendo autor de uma vasta obra literária, com realce para a Cronografia, 
onde analisa as vidas dos imperadores dos séculos $\mathrm{x}$ e $\mathrm{xI}$ (de Basílio II a Miguel VII), num registo muito inovador (impessoal e psicologicamente penetrante) e beneficiando igualmente do facto de ter testemunhado muitos dos acontecimentos que decidiu relatar (Signes 2005). Tendo nascido numa família da classe média, Miguel Pselo recebeu uma educação esmerada e tornou-se um dos conselheiros mais escutados por Constantino IX Monómaco; participou nas intrigas da corte como partidário dos Ducas e tornou-se precetor dos filhos de Miguel VII. Apaixonado por Platão e despido de preconceitos desfavoráveis a respeito dos autores pagãos, Pselo teve contudo o cuidado de evitar conflitos com a Igreja; compôs numerosos elogios aos soberanos que serviu e não há praticamente nenhum domínio do conhecimento em que não tenha deixado um contributo, mesmo que nem sempre original. Como observa Cheynet (2001 123), "a sua obra revela o peso das solidariedades e das amizades, assim como a força das redes de relação pessoais".

Até meados do século xi, ainda houve alguma estabilidade e vitórias importantes sobre os Árabes (como a reconquista de Edessa, em 1032), sobre os Búlgaros (que se revoltaram em 1041) e sobre os Russos (que cercaram Constantinopla pela última vez em 1041), para além da reconquista da parte oriental da Sicília pelo famoso general Jorge Maniakés (de 1038 a 1042). No entanto, o surgimento dos Turcos Seljúcidas na frente leste, dos Normandos na frente ocidental e até de povos das estepes (como os Petchénègues, os Uzi e os Cumani) a norte, como que substituindo as velhas ameaças búlgara e russa, faziam antever o pior. Além do mais, foi nesta época que a aristocracia fundiária viu o seu poder reforçado, graças a isenções fiscais e a imunidades judiciárias que desaguaram na instituição da prónoia (isto é, concessão), uma nova técnica fiscal que inicialmente permitia remunerar a parentela imperial, mas cujo benefício foi depois estendido aos funcionários do Estado, 
nomeadamente aos oficiais, tornando-se o seu modo de pagamento normal; como explica Jean-Claude Cheynet (2001 81), a prónoia transferia para o beneficiário um privilégio fiscal, ou seja, o Estado dava terras aos poderosos (de forma temporária e vitalícia) para que estes as administrassem, cabendo-lhes receber as rendas; foi uma espécie de marca da "feudalização do Estado bizantino", pois o beneficiário da prónoia tornava-se um verdadeiro 'senhor' dos camponeses a quem cobrava o imposto; enquanto o poder central foi razoavelmente forte (até à centúria de Trezentos), ainda pôde fazer respeitar as condições de atribuição do privilégio e evitar as exações dos beneficiários perante os seus contribuintes, pondo fim à concessão quando o serviço que justificava o seu pagamento cessava; mas, na fase terminal do império, a prónoia passaria a ser hereditária.

À morte de Constantino IX, Teodora tornou-se a última mulher a governar em Bizâncio, mas apenas durante um ano e meio (1055-56) e sob o claro domínio dos eunucos que pululavam na corte; seguiu-se um quarto de século de confusão. Primeiro, com Miguel VI Bringas (1056-1057), um dignitário que fora próximo de Teodora mas que foi rapidamente deposto por uma revolta popular; depois, com Isaac I Comneno (1057-1059), um membro da aristocracia militar da Ásia Menor, que depressa a aristocracia civil de Constantinopla substituiu por um dos seus líderes: Constantino X Ducas (1059-1067). Foi todo um tempo de deterioração do sistema político e militar, o que facilitou a saga dos Normandos em Itália (nomeadamente da família Guiscard, que chegou a prender o papa Leão IX na batalha de Civitate, em 1053, e que, seis anos volvidos, se uniu com a Santa Sé, contra Bizâncio). Nos Balcãs, o expansionismo húngaro levou à queda de Belgrado, em 1064, o ano em que os Uzi devastaram o território bizantino, até à Grécia. Todavia, o perigo principal resultou da afirmação do poder dos Turcos Seljúcidas, a Oriente: eles dizimaram o Império Árabe, 
tomaram Bagdade em 1055 e reduziram o califado abássida a uma importância residual (embora tenha sobrevivido até 1258).

Os Turcos assumiram, assim, o programa expansionista antibizantino dos Árabes: em 1065, anexaram a Arménia, dois anos mais tarde conquistaram Cesareia da Capadócia e, em 1071, obtiveram uma vitória espetacular e decisiva, em Manzikert (bastante a sudeste de Trebizonda, junto ao lago Van Gölü, perto da atual fronteira da Turquia com a Arménia, o Azerbaijão e o Irão). Nesta batalha, provavelmente a mais famosa da história do Império Bizantino (Haldon 2001 112-127), o coimperador Romano IV Diógenes (um general que a viúva de Constantino X Ducas, Eudóxia, elevara ao trono, casando com ele) foi estrondosamente derrotado e preso pelo sultão seljúcida, Alp Arslan (1063-1073). Na ressaca, Romano IV foi afastado e cegado por Miguel VII Ducas (1067/71-1078) e pode bem dizer-se que este foi o começo do desmoronamento do Império Bizantino. Aliás, logo em 1071, Bizâncio perdeu Bari para Roberto Guiscard (após três anos de cerco), seguindo-se a Croácia e o principado sérvio de Zeta (Montenegro), entre outros territórios. Também internamente, grassava uma tremenda crise económica, decorrente da ação do logóteta Niceforitze (o principal ministro de Miguel VII), que gerara uma enorme inflação ao declarar como monopólio estatal o comércio dos cereais (Ravegnani 2006 126).

Assim, em 1078, o estratego do tema da Anatólia, Nicéforo III Botaniate (1078-1081), depôs o basileús e assumiu o poder, não conseguindo todavia estancar a crise e a luta interna de fações: logo em 1081, um outro chefe militar da Ásia Menor, Aleixo I Comneno, derrubou-o do trono e deu início à famosa dinastia dos Comnenos. O império bem precisava de um novo fôlego, até porque, em 1078, já os Seljúcidas tinham anexado uma grande parte da Península da Anatólia, com o príncipe Suleiman a fundar em antigo território bizantino o sultanato de Icónio (também chamado, muito simbolicamente, “do Rum”, ou seja, "sultanato romano"), 
com capital em Niceia (e mais tarde em Icónio). Neste momento delicadíssimo, restava a Bizâncio, que perdera já as suas regiões mais prósperas e dinâmicas, a parte ocidental da Ásia Menor (com Constantinopla à cabeça) e as costas do Mediterrâneo e do mar Negro! Seria possível ao velho Império Bizantino sobreviver por muito tempo mais?

As dinastias dos Comnenos e dos Anjos (esta de muito curta duração) foram as últimas do período médio bizantino, tendo-se prolongado até 1204 , o ano em que os cruzados concretizaram a insólita conquista de Constantinopla. Foram dinastias importantíssimas, em especial a dos Comnenos, que lutaram denodadamente pela recuperação do império, negociando soluções inovadoras (como a aliança com Veneza), mas que se viram confrontadas, por causa do avanço dos Turcos, com o problema das Cruzadas na Terra Santa e com a degeneração progressiva do espírito original deste projeto. Toda esta situação criou um caldo civilizacional que obrigou Bizâncio a abrir-se mais ao exterior, rompendo com o isolamento que lhe era próprio e ocidentalizando algumas das suas práticas, nomeadamente a nível económico. Foi também um tempo de grandes escritores, os mais célebres dos quais foram Ana Comnena (autora da famosa Alexíada, em que narra a vida do pai, o imperador Aleixo I Comneno), Nicéforo Briénio (o marido de Ana, elevado à condição de kaîsar e autor de uma obra inacabada sobre a segunda metade do século xII), João Cínamo (o secretário de João II Comneno, no terceiro quartel do século xII) ou Niceta Coniate (um alto funcionário que escreveu sobre os acontecimentos desde o reinado de João I até ao final do período dos Anjos, em inícios do século XIII).

Aleixo I (1081-1118) teve um início de reinado terrivelmente difícil, devido sobretudo à pressão dos Normandos, cujo líder histórico, Roberto Guiscard, possuído por uma "bulimia conquistadora" 
(Delumeau / Heullant-Donat 2000 114), abandonou a Itália em 1081 para atacar Bizâncio, tendo ocupado Corfu (uma ilha do mar Jónico, na atual costa albanesa) e cercado Durazzo (Albânia), com o evidente propósito de marchar depois sobre Constantinopla. Nesta aflição, Bizâncio foi salva por uma aliança urdida por Aleixo I com a cidade semi-independente de Veneza (receosa do expansionismo normando), aliança essa que teria uma repercussão imensa no futuro do império. Graças ao apoio naval veneziano, o cerco normando a Durazzo fracassou; como recompensa, Aleixo I - medindo mal os riscos desta sua generosidade - atribuiu ao doge (o dirigente máximo) veneziano a alta dignidade de prōtosebastós (a título hereditário e colocando-o ao nível da família imperial bizantina, com o respetivo estipêndio), elevou o patriarca de Grado (antigo patriarcado de Aquileia, em Itália) à dignidade de bypertímios (uma grande honra eclesiástica) e, sobretudo, comprometeu-se a pagar 20 libras de ouro anuais aos Venezianos (que estes podiam distribuir pelas suas igrejas) e ordenou que todos os Amalfitanos com lojas em Constantinopla (e não só) pagassem 3 moedas de ouro por ano à Igreja de São Marcos, em Veneza; além disso, foram outorgadas aos de Veneza generosas concessões imobiliárias em Durazzo e na capital bizantina (um comprido quarteirão comercial ao longo do Corno de Ouro, o porto natural da cidade) e foram-lhes ainda concedidos enormes privilégios comerciais: isenções de taxas, exclusão de ficar sob a jurisdição dos funcionários marítimos bizantinos em vários dos centros comerciais mais importantes do império e ainda outros (Ravegnani 2006 132-133)!

Quando os Petchénègues, com o apoio dos bogomilos (uma seita de inspiração maniqueísta) e dos Turcos, atacaram os Balcãs, em 1087, Aleixo I defendeu-se à boa maneira bizantina: fez uma aliança com os Cumani (um povo nómada, oriundo das estepes russas) e conseguiu uma vitória relevante na batalha do monte Levunião, em 1091; a seguir, forçou o emir de Esmirna a levantar o 
cerco a Constantinopla, patrocinando uma revolta local contra ele; por fim, livrou-se dos Cumani (que derrotou) e preparou-se para atacar os Turcos na Ásia Menor, de modo a desafogar a situação geoestratégica de Bizâncio; todavia, acabou por não concretizar este seu projeto, em resultado da chegada da Primeira Cruzada a Constantinopla.

As Cruzadas tinham sido lançadas pelo papa Urbano II no encerramento do Concílio de Clermont, em finais de 1095. O objetivo era canalizar para o Oriente a violência destruidora da cavalaria feudal, atribuindo-lhe um objetivo mais nobre: a libertação dos Lugares Santos, associados à vida de Jesus Cristo (Monteiro 2006 167-168). Bizâncio tinha solicitado a Roma auxílio militar na luta contra os Turcos, que como vimos já haviam engolido uma grande percentagem do território imperial, mas não estava à espera do que surgiu em Constantinopla a partir da primavera de 1096: primeiro, uma "Cruzada popular", chefiada por dois visionários (Pedro, "o Eremita" e Gualter "Sem Haver") postos à cabeça de uma turba imensa e mal armada, que Aleixo I depressa tratou de colocar do lado nascente do Bósforo e que foi imediatamente chacinada pelos Turcos; depois, um exército de cerca de 100000 cavaleiros, liderado por uma série de príncipes ocidentais, entre os quais Boemundo de Tarento (o filho de Roberto Guiscard!). Bizâncio reagiu com mil cautelas e fez um acordo com os cruzados: dar-lhes-ia apoio logístico e militar, com vista à reconquista de Jerusalém, mas, em troca, os "Francos" (nome por que eram conhecidos os primeiros cruzados, dado serem na sua grande maioria oriundos da França) jurar-lhe-iam fidelidade e entregariam a Bizâncio as terras que reconquistassem aos Turcos.

Negócio feito, os cruzados lá avançaram e, até ao verão de 1099, obtiveram uma série notável de sucessos, o que lhes permitiu fundar três Estados latinos na Terra Santa: o condado de Edessa (por Balduíno de Bolonha, em março de 1098), o principado de 
Antioquia (por Boemundo de Tarento, em junho de 1098) e o reino de Jerusalém (entregue a Godofredo de Bulhão, duque da Baixa Lorena, em julho de 1099); em 1102, seria ainda fundado, por Raimundo de Saint-Gilles, conde de Toulouse, o condado de Trípoli. Quanto à prometida restituição de territórios a Bizâncio, nada: os cruzados alegaram que Aleixo I não tinha cumprido a sua parte, designadamente quando os Francos se viram aflitivamente cercados em Antioquia pelo emir turco de Mossul, Kerboga, e este desencontro inquinou definitivamente as relações entre Gregos e Latinos. Em conformidade, Aleixo I iniciou uma guerra sem quartel ao principado ítalo-normando de Antioquia, acabando por obrigar Boemundo de Tarento a submeter-se e a declarar-se seu vassalo, em 1108 (ainda que o território tenha ficado nas mãos de Tancredo de Hauteville, um sobrinho de Boemundo).

João II Comneno (1118-1143) prosseguiu a obra do pai e enfrentou os Seljúcidas na Ásia Menor (em 1119) e os Petchénègues nos Balcãs (na Macedónia e na Trácia, obtendo uma vitória decisiva em 1122). A seguir, teve de se ocupar da ameaça protagonizada pelos Sérvios e pelos Turcos.

Como recorda Giorgio Ravegnani (2006 137-138), os Sérvios eram originários do norte dos Cárpatos, e Heráclio tinha-os fixado nos Balcãs, para conter os Ávaros. A sua origem étnica é incerta, mas acabaram por se misturar com a população eslava local, embora tivessem estabelecido duradouramente relações culturais e políticas estreitas com Bizâncio; as suas comunidades chamavam-se zupanije (ou zupe) e eram governadas por um príncipe (zupan). Bizâncio parece ter tido sobre os Sérvios uma soberania nominal até meados do século ix: no tempo de Basílio I (867-886), os Sérvios aceitaram o cristianismo ortodoxo e a vassalagem política ao império, mas, em meados do século xI, o maior principado sérvio (conhecido como Diocleia ou Zeta) tornou-se independente, situação que seria confirmada pelo papa Gregório VII (o pontífice 
da célebre "reforma gregoriana"), desejoso de fazer entrar a Igreja sérvia na órbita romana. Nos inícios do século xII, o principado de Zeta entrou em decadência, verificando-se em contrapartida a ascensão do governador de Rascia (o nome deriva do forte de Ras, a residência do príncipe); no entanto, a experiência não foi muito duradoura: João II Comneno venceu o zupan de Rascia, e a guerra travada com a Hungria a partir de 1128 terminou com um acordo favorável a Bizâncio; assim, em finais da centúria, a Sérvia já estava novamente sob a supremacia imperial, embora tenham ocorrido muitas rebeliões, pelo menos até à segunda metade do século xiII.

Quanto aos Húngaros (ou Magiares), tinham relações com Bizâncio desde o século vi, quando viviam entre o rio Danúbio e o Cáucaso. No século Ix, migraram para poente e alcançaram a margem norte do estuário do Danúbio; nos finais dessa centúria, a pressão dos Petchénègues deve tê-los empurrado para a Panónia, onde, em 906, destruíram o reino da Morávia. A partir daí, efetuaram incursões regulares, quer contra o Ocidente, quer contra Bizâncio, mas - como já sabemos - em 955 foram copiosamente derrotados por Otão I na batalha de Lechfeld; estes desaires puseram fim ao nomadismo húngaro e, pouco depois, este povo tornou-se uma nação estável, graças sobretudo à ação do príncipe Géza e do seu filho, Vajk (isto é, herói), o primeiro rei da Hungria, que adotou o nome de Estêvão I (1000-1038). Ao converterem-se ao cristianismo em 970, os Magiares entraram na órbita religiosa romana, mas conservaram estreitas relações políticas e culturais com Bizâncio, até porque, durante dois séculos, mantiveram uma fronteira comum. Há mesmo notícia do envio, por Constantino IX Monómaco e por Miguel VII Ducas, de coroas a alguns monarcas húngaros, e também sabemos que Géza I casou com uma sobrinha do imperador Nicéforo III Botaniate (1078-1081), chamada Sinadena Teodoro. Em 1104, uma filha do rei magiar Ladislau I (de nome 
Piroska) casou com o basileús João II Comneno e tornar-se-ia imperatriz e augusta (Ravegnani 2006 138-140).

A João II deve-se também uma ofensiva militar bem-sucedida na Ásia Menor, com a submissão dos emirados de Melitena e da Cilícia, um ataque a Antioquia (que forçou o príncipe latino, Raimundo de Poitiers, a jurar fidelidade ao basileús, em 1137) e com a recuperação da Panfília. O imperador estaria a preparar-se para recuperar a Palestina quando encontrou a morte durante uma caçada, em 1143. Um balanço imparcial do reinado de João II deve ainda lembrar a degradação das relações com Veneza, pois o basileús começou por se recusar a cumprir o leonino contrato assinado pelo seu pai, e a grande cidade mercantil retaliou com represálias navais a partir de 1122, obrigando o imperador a recuar e a renovar, em 1126, o acordo original...

Curiosamente, João II escolheu como sucessor, não o seu primogénito (Isaac), mas um filho mais novo, Manuel, que considerava mais habilitado para o efeito; esta decisão implicou uma entorse no princípio político da Antiguidade, que era vulgarmente aceite na tradição imperial bizantina.

Manuel I Comneno (1143-1180) intensificou a abertura de Bizâncio ao Ocidente e imprimiu ao império o derradeiro impulso expansionista. $\mathrm{O}$ seu longo reinado pode dividir-se em duas partes, separadas pelo desastre militar ocorrido em Miriocéfalo, em 1176, contra os Turcos.

No início do seu principado, Manuel I teve de concentrar a sua atenção no acompanhamento da Segunda Cruzada, um projeto inteiramente falhado (salvo a conquista, absolutamente periférica, de Lisboa aos Mouros) e que decorreu entre 1147 e 1149, sob a liderança de dois poderosos monarcas ocidentais: Luís VII, rei de França, e Conrado III, titular do Sacro Império Romano-Germânico (Monteiro 2006 174-176). Com o príncipe normando da Sicília, Rogério II, a aproveitar as dissensões entre os cruzados (e entre 
estes e os Bizantinos) para tomar Corfu e devastar a Grécia (com as capturas provisórias de Tebas e de Corinto), Manuel I teve de renovar a aliança com os Venezianos, concedendo mais privilégios; ainda pensou atacar os Normandos em Itália, com o auxílio do seu cunhado Conrado III (os descendentes dos Otões mantinham vivo o sonho de dominar a Itália), todavia os Venezianos fizeram abortar o projeto para não correrem o risco de verem os Bizantinos instalados nas duas margens do Adriático. Então, Manuel I recrutou mercenários e resolveu atacar sozinho, com o apoio do papa Adriano IV, tendo começado por obter um sucesso na Apúlia, mas sofrendo depois um grave revés em 1156, diante de Guilherme I, o novo rei siciliano. Em 1158, foi assinado um tratado entre Bizâncio e os Normandos, que praticamente expulsou os Bizantinos da Península Itálica! Esclarecido quanto à política veneziana (que optara pela neutralidade naquele conflito), Manuel I virou-se para Génova, outra poderosa república marítima italiana, porém a diplomacia normanda gorou qualquer aliança.

Mais sorte teve Manuel I noutras paragens: contra os Estados latinos do Oriente, conseguiu obter a submissão definitiva da importantíssima cidade de Antioquia, em 1159; nos Balcãs, foi bem-sucedido contra os Húngaros, e submeteu a Dalmácia, a Croácia, a Bósnia e Sirmio (em 1167), para além de ter dominado a rebelião de um príncipe sérvio, Estêvão Nemanja, em 1172. Eram passos importantes para uma reconquista territorial significativa, embora as bases fossem frágeis e os sacrifícios financeiros estivessem a tornar-se cada vez mais difíceis de suportar pela população.

Em 1175/1176, Manuel I organizou uma campanha contra o sultanato turco de Icónio, mas foi severamente derrotado em Miriocéfalo (na Frígia, no centro-oeste da Ásia Menor), em setembro de 1176. Esta derrota, que Ravegnani (2006 144) compara a Manzikert - 1071, assinalou o fim da restauração comnena e o início do processo de desagregação do aparelho estatal bizantino. 
Para agravar a situação, Veneza, desconfiada das ambições italianas do basileús (p. ex.: apoio às comunas do Norte, na luta contra o imperador Frederico I "Barba Ruiva"), cortou com Bizâncio, o que levou Constantinopla a ordenar, no dia 12 de maio de 1171, a detenção de todos os Venezianos que estivessem em território imperial! Em retaliação desta megaoperação policial, de que resultaram muitos prisioneiros, Veneza organizou uma frota de 100 navios e, sob o comando do doge Vital II Miguel, atacou algumas ilhas gregas (Eubeia, Kios, Lesbos, entre outras), numa ação que acabou por abortar devido a uma epidemia e ao mau tempo, que forçaram a esquadra italiana a regressar destroçada a sua casa, em 1172. O doge acabou por ser assassinado, mas o seu sucessor, Sebastião Ziani, manteve a guerra a Bizâncio: fomentou a revolta sérvia, cedeu navios a Frederico I (inimigo declarado dos Gregos) e, após um acordo com os Normandos da Sicília, obrigou Manuel I a negociar, em 1179; daqui resultou a libertação de alguns prisioneiros venezianos, mas a morte do imperador não permitiu outras evoluções.

Os últimos dois imperadores dos Comnenos, Aleixo II (11801183) e Andrónico I (1183-1185) tiveram reinados muito curtos e malsucedidos. O primeiro, Aleixo II (filho de Manuel, que herdou o trono ainda menor, ficando sob a frágil regência da imperatriz Maria), foi vítima de um ambiente cada vez mais hostil aos Latinos, sobretudo em Constantinopla, das dificuldades de gestão do dossiê das Cruzadas, dos problemas religiosos e dos nacionalismos bizantinos. O segundo, Andrónico I, primo de Manuel, impôs-se pela força e mandou matar a imperatriz-mãe (que assumira o hábito monástico por imposição prévia do marido) e o próprio soberano legítimo, Aleixo II! Mas nem por isso este antigo governador do Ponto teve um principado tranquilo: em maio de 1182, uma marcha sobre Constantinopla conduziu ao massacre dos Latinos ali residentes (nomeadamente Genoveses e 
Pisanos) pela população enfurecida; no entanto, esta política (de novo) isolacionista e antiocidental, se podia ser muito popular na capital bizantina, não dispensou Andrónico I de reatar com Veneza, a quem foi restituída a maior parte dos privilégios outorgados por Aleixo I, para além de indemnizações chorudas pelos acontecimentos de 1171. No fundo, Andrónico tentava conter como podia a desagregação do aparelho estatal e a corrupção (venda de cargos políticos, extorsões fiscais, por exemplo), instituindo para o efeito um ambiente altamente repressivo e brutal. Todavia, as derrotas sucessivas averbadas em diversos tabuleiros (contra os Húngaros e os Sérvios, ou contra os Normandos, que em 1185 tomaram Tessalónica e avançaram sobre Constantinopla) acabaram por desgraçar o usurpador, que terminou linchado pela multidão nas ruas da capital do império...

Chegava ao fim a era dos Comnenos, dinastia que - como observa Jean-Claude Cheynet (2001 136) - fizera assentar o seu estilo de governação em três mandamentos: i) uma centralização crescente; ii) a valorização da família imperial; iii) a procura do apoio da Igreja e da população de Constantinopla. A seguir aos Comnennos, vieram os Anjos (ou Ângelos), que nem por isso salvaram Bizâncio da decadência; esta breve dinastia (de 1185 a 1204), promovida pela aristocracia feudal, reuniu apenas quatro monarcas. O primeiro foi Isaac II (1185-1195), um primo de Andrónico que conseguira refugiar-se em Santa Sofia e que foi aclamado imperador; teve capacidade para forçar os Normandos a abandonarem o território imperial, mas sofreu grandes humilhações às mãos dos Búlgaros (que em 1187 constituíram uma espécie de segundo império, em versão minimalista) e, sobretudo, foi apanhado pela Terceira Cruzada na Terra Santa (1189-1192), à frente da qual vinha justamente Frederico I "Barba Ruiva", acompanhado por Ricardo "Coração de Leão", rei de Inglaterra, e por Filipe II "Augusto", soberano da França... 
Constantinopla temeu o pior, e são conhecidas as alianças de Isaac II Anjo com Saladino (o grande líder turco e sunita que unificara os muçulmanos, reativara a jihad e reconquistara Jerusalém em 1187), assim como o envio de novas embaixadas a Veneza, igualmente receosa da ameaça germânica. O afogamento de Frederico I na Cilícia, em 1190, facilitou a vida ao novo basileús, que no entanto viu Ricardo conquistar Chipre, em maio de 1191, tornando a ilha uma excelente base de operações contra a Síria-Palestina. A Terceira Cruzada não permitiu aos ocidentais reconquistar senão uma faixa costeira dos velhos Estados latinos, falhando o objetivo principal (a reconstituição do reino de Jerusalém), mas Isaac II acabou por ser deposto pelo seu próprio irmão, Aleixo III, que o cegou e encerrou na prisão.

Aleixo III (1195-1203) teve de fazer face às ambições do novo imperador germânico, Henrique VI (dono do trono siciliano e cunhado de Isaac II), e obrigou-se ao pagamento de um pesado tributo (a chamada "taxa alemã") para evitar a guerra; foi nessa altura que começaram a ser removidos dos túmulos imperiais bizantinos os ornamentos mais valiosos, um sinal claro da exaustão do Tesouro (Ravegnani 2006 151). Aleixo III tentou favorecer sistematicamente Génova e Pisa (uma jovem potência marítima em ascensão), assim como Ragusa, à custa de Veneza e, para poupar o erário público, suspendeu os pagamentos e as ajudas aos Venezianos; contudo, tal como sucedera com João II Comneno, acabaria por recuar e, em 1198, acabou por assinar um novo tratado bizantino-veneziano, que repôs a aliança anterior.

O pior, porém, no que à dinastia dos Anjos diz respeito, estava guardado para o fim: em 1198, o papa Inocêncio III lançou a Quarta Cruzada, que deveria partir de Veneza. O astuto doge Henrique Dandolo (nonagenário e quase totalmente cego) soube negociar com os promotores franceses da expedição o preço do transporte em navios venezianos. Quando os cruzados se juntaram, faltavam 
muitos homens e... muito dinheiro; os Venezianos propuseram atacar Zara, uma cidade da margem esquerda do Adriático, que era uma adversária comercial dos Venezianos. Os cruzados, endividados, aceitaram; no entanto, nem assim conseguiram pagar a sua dívida. Foi então que surgiu uma proposta veiculada por um filho do velho e cego Isaac II, detido nas masmorras de Constantinopla: dizia este outro Aleixo que, se os cruzados e os Venezianos repusessem o seu pai no trono, saldariam todas as dívidas da operação e ainda os ajudariam a reconquistar Jerusalém (Monteiro 2006 177-179)!

E assim foi: Aleixo III foi destronado, Isaac II foi reposto no trono (como era cego, o seu filho tornou-se imperador associado, sob o nome de Aleixo IV: 1203-1204) e os ocidentais ficaram à espera que Constantinopla cumprisse a sua parte do acordo. Não obstante, Aleixo IV só conseguiu reunir metade da verba e solicitou um adiamento; o tempo foi passando e os nervos foram crescendo, dentro e fora da capital; em janeiro de 1204, Aleixo V Ducas Murzuflo encabeçou um golpe de Estado, prendeu e estrangulou Aleixo IV; quanto ao velho Isaac II, morreria dias depois, na prisão. Como era alheio ao negócio com os ocidentais, Aleixo V recusou-se a pagar-lhes qualquer indemnização; sentindo-se traídos, os cruzados e os Venezianos assaltaram Constantinopla e tomaram a maior cidade cristã do mundo, em abril de 1204! Por fim, um exército conseguia conquistar a capital do Império Bizantino, que depois foi fortemente saqueada e semidestruída (felizmente, os Venezianos tiveram a ideia de poupar muitas obras de arte, que ainda hoje se podem admirar em Itália).

Após este insólito grand final de uma Cruzada lançada pela Santa Sé, os cruzados e os Venezianos repartiram entre si os despojos. Nascia desse modo o Império Latino do Oriente, que duraria até 1261: Balduíno da Flandres ficou como imperador, enquanto o novo patriarca de Constantinopla (Tomás Morosini) foi escolhido entre os Venezianos. O Império Bizantino foi dividido, 
com uma quarta parte para o imperador Balduíno (centrada em Constantinopla, na Trácia, na Ásia Menor e nas ilhas gregas) e o resto a ser repartido entre os Venezianos e os cavaleiros cruzados. No entanto, permaneceram muitas zonas por submeter, pelo que houve necessidade de ajustamentos posteriores, em resultado da resistência grega e de outros fatores.

A conquista ocidental das províncias bizantinas (sem grande oposição, ao que se sabe) decorreu entre finais de 1204 e 1205, conduzindo a diversos Estados semi-independentes no seio do Império Latino, em especial:

i) o reino de Tessalónica, em 1205, exigido por Bonifácio de Montferrato e com jurisdição sobre a Macedónia e a Tessália;

ii) o ducado de Atenas (incluindo a Ática e a Beócia), em 1205, a favor do borgonhês Otão de la Roche, com o apoio do rei de Tessalónica;

iii) o principado de Acaia ou da Moreia (no Peloponeso), constituído em 1205, por Guilherme de Champlitte e Godofredo de Villehardouin.

Veneza obteve, claro está, imensas vantagens, embora tivesse renunciado à Grécia continental, o que teria tornado a cidade lagunar uma potência também terrestre: para além de controlar Durazo, Corfu e uma parte da Eubeia, entre outros territórios, Veneza ficou com os melhores portos do mar de Mármara e do Helesponto, com possessões na Trácia (como Adrianopla) e com um enorme quarteirão em Constantinopla. O sábio Henrique Dandolo morreu em 1205, mas o novo doge ficou dono e senhor de "quarta parte e meia do império da România" (ou seja, de metade do que sobrava, depois de retirado o quarto do imperador latino)! Ao que se sabe, Veneza aproveitou muito melhor do que os cruzados este sucesso 
em Constantinopla, estabelecendo uma prefeitura na capital e sabendo construir um grande império mercantil; além do mais, tinha sido suficientemente astuta para escusar o doge de jurar fidelidade ao imperador latino, e também era menos vulnerável ao efeito das tradicionais forças centrífugas feudais (Ravegnani 2006 158).

\subsection{A época tardia: da resistência no exilio de Niceia (1204-1261) à conquista de Constantinopla pelos Turcos Otomanos (1453):}

Apesar de a oposição à conquista franco-veneziana não ter sido feroz, alguns aristocratas fugiram para zonas que os Latinos ainda não tinham ocupado e, a partir dessas posições, onde criaram governos independentes, organizaram a resistência bizantina. Devemos evidenciar, sem prejuízo de alguns enclaves mais pequenos e menos relevantes que surgiram na Ásia Menor:

i) o chamado "império de Niceia", na Ásia Menor, criado logo em 1204 por Teodoro Lascaris, genro de Aleixo III (personagem que fugira do cerco cruzado a Constantinopla); Lascaris fez-se coroar imperador quatro anos mais tarde, por um patriarca (Miguel Autoriano) que ele próprio nomeou;

ii) o despotado do Epiro (Albânia/Grécia), a partir de 1205, no noroeste da Grécia, com capital em Arta; foi fundado por Miguel Anjo (ou Ângelo), um cunhado de Isaac II e de Aleixo III;

iii) o "império de Trebizonda", a sul do mar Negro, logo a partir de abril de 1204, com os irmãos Aleixo e David Comneno, sobrinhos de Andrónico I, que reclamavam o título imperial; devido à sua posição mais periférica, esta 
formação resistiria até à conquista turca de 1453 (ou até um pouco além disso).

Claro que os Latinos quiseram de imediato sufocar o império de Niceia e, em finais de 1204, atacaram a Ásia Menor, mas a ocorrência de uma revolta bizantina na Trácia, em fevereiro de 1205, com o apoio do czar búlgaro Kalojan, obrigou à suspensão das operações. A 14 de abril de 1205, o imperador latino foi pesadamente derrotado pelos Búlgaros nas proximidades de Adrianopla; Balduíno foi preso neste combate, em que tombou a fina flor da cavalaria cruzada, e nunca mais foi devolvido pelos seus captores. Perante estes reveses, muitos cruzados, em pânico, optaram por regressar à Europa; por isso, os Ocidentais viram-se obrigados a evacuar a Ásia Menor, e o império de Niceia respirou de alívio. Teodoro Lascaris organizou então o seu novo Estado com base no modelo bizantino, constituindo uma espécie de 'governo imperial no exílio', de tal maneira que ainda hoje os historiadores consideram os governantes de Niceia, entre 1204 e 1261, como legítimos sucessores de Aleixo V Ducas Murzuflo. O sucessor de Balduíno (o seu irmão Henrique da Flandres), depois de travar os Búlgaros, tentou eliminar o império de Niceia, mas não dispôs de meios para tanto e, em 1214, acabou por assinar o Tratado de Ninfeia, que definia as fronteiras entre os dois impérios (o latino, que conservou a costa noroeste da Ásia Menor, e o de Niceia).

Um outro epígono relevante de Bizâncio foi o despotado do Epiro, que controlava também a Acarnânia e a Etólia e que Teodoro Anjo tornou uma potência antilatina; em 1224, conquistou Tessalónica e pôs fim a esse reino latino (mantido pelos sucessores de Bonifácio de Montferrato, liquidado pelos Búlgaros em 1207). Teodoro, que também dominava uma grande parte da Macedónia, chegou mesmo a proclamar-se imperador dos Romanos e a reclamar a herança bizantina, criando por conseguinte uma situação de enorme rivalidade 
relativamente a Niceia. Assim, em 1225, o Império Latino estava praticamente reduzido a Constantinopla e aos seus arredores, mas acabaria por sobreviver durante mais algumas décadas.

O novo imperador de Niceia, João III Ducas Vatatzès (1222-1254), submeteu rapidamente quase tudo aquilo que restava da Ásia Menor latina e ainda conquistou Adrianopla, na Trácia. Ficou assim aberta a via para Constantinopla, cidade-ícone que passou a ser disputada por três potências: pelos Latinos, que a queriam preservar a todo o custo, pelo imperador de Niceia e pelo déspota do Epiro (agora também chamado imperador de Tessalónica). Mas não podemos esquecer a ambição dos Búlgaros, tanto mais que o novo czar, Ivan II Asen, tinha o mesmo sonho de Simeão: formar um império búlgaro-bizantino com capital em Constantinopla!

Sabendo disso, os Latinos, para sobreviverem aos dois rivais mais próximos, decidiram aliar-se ao czar e, após a morte do imperador Roberto de Courtenay (em 1228), até pensaram confiar-lhe a regência do jovem Balduíno II! Na sequência desta aliança contranatura, Teodoro Anjo foi derrotado e preso pelos Búlgaros, na batalha de Klokotnica-Marizza (em 1230), o que provocou um apagamento significativo da potência do Epiro-Tessalónica, para gáudio dos de Niceia. Porém, em tempo de alianças extremamente volúveis, no ano seguinte os Latinos mudaram de planos e elegeram como coimperador o ancião João de Brienne, descendente de uma distinta família de cruzados. Sentindo-se enganados, os Búlgaros, por sua vez, aliaram-se a Niceia em 1235, contando com a simpatia discreta do novo imperador de Tessalónica, Manuel Anjo (irmão de Teodoro). Os aliados cercaram Constantinopla por mar e por terra, em 1235 e em 1236, mas a conquista não era fácil, e o czar Ivan II entendeu-se de novo com os Latinos, vindo a abandonar a disputa em 1237.

Deste modo, Niceia ficou com as mãos livres para enfrentar sozinha Constantinopla, mas João III Vatatzès não teve tempo para 
cumprir o seu sonho (a reconstrução do Império Bizantino), devido ao surgimento de um dado novo: a invasão mongol da Europa oriental, em 1242, impulsionada pelo khan Ögedey (o sucessor do lendário Gengis khan). No ano seguinte, os Mongóis destroçaram o exército dos Seljúcidas do Rum na batalha do desfiladeiro de Köse Dagh (no nordeste da atual Turquia), criando assim um novo quadro geoestratégico na região. Niceia foi obrigada a entender-se com os Turcos para conseguir sobreviver, enquanto os Mongóis avançavam até à costa do Adriático. No entanto, a investida mongol foi de curta duração e acabou por ter efeitos colaterais benéficos para os de Niceia, uma vez que debilitou os seus principais vizinhos e potenciais adversários orientais: o imperador de Trebizonda e o sultão turco de Icónio, que se tornaram vassalos dos invasores mongóis.

Embora sem ter conseguido alcançar o seu objetivo final, João III duplicou a extensão do império de Niceia, que conheceu também nesta época um significativo florescimento cultural. Para sobreviver, o imperador latino, Balduíno II, estava agora obrigado a mendigar apoios no Ocidente, no decurso de uma viagem de vários anos em que chegou a ceder relíquias preciosas (como a coroa de espinhos e outras, que Luís IX de França acolheria na sua preciosa Sainte-Chapelle, em Paris); até o filho do imperador latino, Filipe, foi entregue em penhor do apoio dos Venezianos! Na linha do que Aleixo III tinha já sido obrigado a fazer com os ornamentos tumulares, foi nesta altura que o chumbo dos tetos dos palácios de Constantinopla começou a ser vendido, para pagar as dívidas (Ravegnani 2006 74-75)... E, apesar de todos estes esforços, o Ocidente (com exceção de Veneza, claro está) abandonou a Constantinopla latina à sua sorte.

A João III sucedeu, em Niceia, Teodoro II Lascaris (1254-1258), um homem de cultura, que desenvolveu os estudos humanísticos, mas que não teve tempo para mais. Quando faleceu, o seu filho e herdeiro, João IV Lascaris (1258-1261), era ainda menor, pelo 
que a regência ficou nas mãos de um prestigiado general, Miguel Paleólogo, que depressa se tornou coimperador. Coube a este último defender Niceia de uma temível coligação que então se organizou e que incluía Manfredo da Sicília, Miguel II do Epiro e Guilherme II de Villehardouin, do principado de Acaia (na costa norte do Peloponeso); em 1259, o Paleólogo derrotou com estrondo esta coligação em Pelagónia (na Macedónia), desferindo um golpe mortal no que restava das ambições epirotas. Niceia e a Constantinopla latina (apoiada por Veneza) ficavam sozinhas em campo e, para enfraquecer a posição da grande cidade mercantil italiana, Miguel Paleólogo optou por se entender com a rival Génova, com quem celebrou o Tratado de Ninfeu, em março de 1261; neste acordo, foram prometidas enormes regalias aos Genoveses, caso Constantinopla fosse reconquistada pelos herdeiros legítimos de Bizâncio. Os Genoveses, ansiosos por ocuparem a posição dos seus concorrentes do Véneto na grande metrópole do Bósforo, enviaram alguns navios para as proximidades, mas Constantinopla acabou por cair, quase de forma fortuita, antes mesmo de eles poderem ser úteis: Aleixo Strategopolo, um general de Niceia, fora enviado à Trácia para assustar os Latinos; ao passar perto de Constantinopla, percebeu que a cidade estava muito mal defendida, uma vez que o grosso da guarnição tinha saído para atacar uma ilha do mar Negro; astuto, o general aproveitou para avançar na noite de 25 de julho de 1261, com o apoio de alguns residentes; Balduíno II foi apanhado de surpresa e pôs-se em fuga com o seu séquito, enquanto o resto dos latinos (incluindo o prefeito veneziano e o patriarca) evacuava a cidade em ritmo de 'salve-se quem puder'. Cinquenta e sete anos após a insólita conquista cruzada, Constantinopla voltava a ficar nas mãos dos Bizantinos!

Foi assim que começou a última dinastia de Bizâncio - a dos Paleólogos. O seu primeiro titular foi justamente o general Miguel, que logo em 1261 mandou cegar João IV Lascaris e se tornou 
imperador único. Muito território tinha sido perdido ao longo do último meio século, mas o império sobrevivera à provação do exílio niceno e Miguel VIII (1259/1261-1282) procurou, quer pela força das armas quer pela habilidade da astuta diplomacia bizantina, recuperar o que podia.

Nos primeiros anos, Miguel VIII conseguiu algumas restituições na Acaia, recuperou aos Búlgaros alguns portos na costa ocidental do mar Negro e forçou o Epiro a reconhecer a soberania imperial; já no Peloponeso, em 1264, sofreu vários desaires contra o príncipe renegado de Acaia. Em relação às cidades mercantis italianas, o primeiro Paleólogo optou por se aliar, ora com Génova, ora com Veneza, para não ficar excessivamente dominado por nenhuma delas; a base de Gálata, no Corno de Ouro, foi então convertida em cidade comercial italiana, transbordando de prosperidade.

Com a subida ao trono da Sicília por Carlos de Anjou (irmão do rei Luís IX de França), as dificuldades de Miguel VIII aumentaram, uma vez que Carlos ambicionava o trono bizantino e pôde contar com o apoio do papa para uma grande expedição contra Constantinopla! O basileús manobrou como pôde para desviar a Santa Sé de uma aliança com os Angevinos e, em 1274, no Concílio de Lyon, foi proclamada a união das Igrejas latina e grega, com enormes cedências bizantinas ao papa italiano Gregório X (o antecessor do único papa português: Pedro Hispano, ou João XXI); o facto, porém, acarretou uma fatura interna pesada para o primeiro dos Paleólogos: uma grande parte da população, apoiada pelos monges e pelos partidários do patriarca deposto de Constantinopla, Arsénio, opuseram-se, obrigando Miguel VIII a duras perseguições aos dissidentes. Para agravar a situação, em 1281, Carlos de Anjou conseguiu fazer eleger o papa francês Martinho IV, favorável aos seus interesses, e este fomentou uma imensa coligação antibizantina, que reunia, além de Carlos e da Santa Sé, os herdeiros do trono latino de Constantinopla (a família dos Courtenay), Veneza (irritada 
pelo facto de Miguel VIII andar a conquistar possessões suas no mar Egeu, através de um pirata italiano: Licário), a Tessália (a norte da Grécia), a Sérvia e a Bulgária! Com a vida de novo presa por um fio, Bizâncio acabaria por ser salva pela eclosão da revolta das Vésperas Sicilianas (Palermo, março de 1282), que Constantinopla deve ter fomentado e que, numa célebre 'noite das facas longas', acabou com o domínio francês na Sicília (e, mais tarde, no sul da Península Itálica), em proveito dos reis de Aragão. Três anos mais tarde, Veneza voltaria a aproximar-se de Bizâncio.

Nessa altura, porém, já era Andrónico II (1282-1328), filho de Miguel VIII, quem ocupava o trono bizantino. Este imperador governou durante quase meio século e começou por pacificar a Igreja bizantina, repudiando a união com Roma, ao mesmo tempo que tomava duras medidas de saneamento financeiro, sobretudo diminuindo as despesas com o exército e a marinha. Em matéria de política externa, Andrónico preferiu o entendimento com Génova e a via diplomática, patrocinando por exemplo o casamento da sua filha com o czar sérvio Milutin, de modo a travar uma perigosa ameaça sobre Tessalónica. Este foi, no entanto, um tempo de grande desvalorização monetária e de empobrecimento da população, salvo dos grandes latifundiários e dos detentores da prónoia. Foi também um tempo de exacerbamento das rivalidades entre Génova e Veneza, que disputaram uma autêntica guerra de influência nos territórios e mares do Oriente; em 1302, foi assinado um armistício entre Veneza e Bizâncio, bastante oneroso, que tornou o império um verdadeiro refém dos seus próprios aliados (Ravegnani 2006 170). Quatro anos depois (1306), Carlos de Valois (irmão do rei de França, Filipe, "o Belo", e herdeiro do trono latino de Constantinopla) concebeu com o papa Clemente V (que excomungou Andrónico II e Veneza) um novo plano de cruzada contra Bizâncio, mas esta não chegaria a concretizar-se. Bastante mais reais foram os efeitos da desastrosa campanha bizantina na Ásia Menor, contra os Turcos. 
Aqui, a presença mongol conduzira à fragmentação do sultanato seljúcida do Rum em diversos emirados, sob o domínio dos descendentes de Gengis khan. Todavia, nos inícios de Trezentos, a potência mongol entrara em declínio e isso possibilitara a afirmação gradual do emirado dos Otomanos (ou Osmanlis), no território da antiga Bitínia (na margem sul do mar Negro). Esta tribo turca fora das últimas a chegar à Ásia Menor, sob o comando de Ertogrul, a quem sucedera o filho Osman (1281-1326), o verdadeiro fundador da dinastia otomana. Excelentes guerreiros, os Otomanos começaram a expandir o seu território e a unificar as tribos turcas, ameaçando perigosamente os interesses de Bizâncio; num ápice, dominaram a Ásia Menor, enfraquecida com a transferência da capital de Niceia para Constantinopla.

Esta ameaça levou, em 1303, Andrónico II a fazer uma aliança com uma companhia mercenária de origem catalã, chefiada por Rogério de Flor. A "Companhia Catalã", que contaria com cerca de 6500 homens, já tinha atuado na Sicília, e Andrónico II chegou a casar uma sobrinha sua com Rogério de Flor, capitão mercenário que elevou à condição de kaîsar! Em 1304, os Catalães derrotaram os Turcos no cerco de Filadélfia, mas o atraso no pagamento dos soldos levou-os a constituírem um principado independente na Ásia Menor. Sentindo-se traída, Bizâncio promoveu o assassinato de Rogério, em 1305, e os Catalães declararam guerra aberta ao império: derrotaram o coimperador Miguel em batalha e, depois, devastaram a Trácia bizantina e rumaram ao norte, onde saquearam o famoso mosteiro de Athos, na Grécia (em 1308), antes de alcançarem a Tessália. Dois anos mais tarde, aliaram-se ao duque franco de Atenas, Gualter de Brienne, mas romperam com ele logo em 1311, tendo-o derrotado e estabelecido então em Atenas um principado catalão destinado a durar sete décadas!

Este ambiente conduziu, em Bizâncio, a uma guerra civil de 1321 a 1328, entre Andrónico II e o seu neto Andrónico III (o filho 
do coimperador Miguel IX, morto em 1320). Do lado do neto, que reagia assim ao seu afastamento da sucessão ao trono, alinhou a jovem aristocracia bizantina, encabeçada por João Cantacuzeno. No final da disputa, o basileús foi obrigado a abdicar e a entrar para um mosteiro, e Andrónico III Paleólogo (1328-1341) subiu ao trono de púrpura, escolhendo como seu braço-direito João Cantacuzeno.

Apesar de os Sérvios e os Búlgaros terem aproveitado a guerra civil para devastarem o território bizantino, a nova dupla governante trouxe algum revigoramento ao império. É certo que Andrónico III foi vencido por Orkhan (filho de Osman) na batalha de Pelékanon (na Bitínia), em junho de 1329, tendo perdido também Niceia (em 1331) e Nicomédia (em 1337), o que o levou a assinar um tratado humilhante com os Turcos, no qual reconhecia o Estado otomano e se obrigava a pagar um pesado tributo anual. Mas, em contrapartida, o novo basileús e o seu primeiro-ministro, Cantacuzeno, conseguiram estabilizar as relações com Veneza, reconstruíram a frota bizantina e obtiveram vários sucessos contra os Genoveses (em Kios, na Fócia, em Gálata) e contra a nova ameaça séria do czar Estêvão Dusan (neste último caso por via diplomática); além disso, reconquistaram a Tessália e o Epiro, aproveitando as disputas internas causadas pela morte de príncipes titulares que não haviam deixado herdeiros.

A morte de Andrónico III, em 1341, abriu um novo período de guerra civil, uma vez que o seu sucessor legítimo, João V Paleólogo, tinha apenas nove anos de idade. Nesta guerra, João Cantacuzeno, então com o estatuto de mégas domestikós, enfrentou o partido da imperatriz-mãe, Ana de Saboia, apoiada pelo patriarca de Constantinopla (João Caleca) e pelo mégas dux (isto é, o comandante da frota), Aleixo Apocauco, que recolhia um significativo apoio popular. A guerra civil prolongou-se por seis anos e, dado que nenhuma das partes conseguia impor-se pelos seus próprios meios, envolveu muitos parceiros externos ocasionais (Sérvios, Seljúcidas, 
Otomanos, Búlgaros, entre outros), o que muito contribuiu para o dilaceramento do que restava do império. Além disso, a questão assumiu também uma dimensão religiosa, com o rebentamento da polémica do hesicasmo, uma doutrina que remetia para o silêncio, para a meditação de tipo oriental, para a contenção da respiração em ordem a avistar a luz divina, muito acarinhada no mosteiro de Athos e inspirada no episódio evangélico do monte Tabor. Os hesicastas, com o teólogo grego Gregório Palamas à cabeça, apoiaram João Cantacuzeno, enquanto os seus adversários (liderados por um monge da Calábria, Barlaão) alinharam com a fação opositora. Durante esta guerra civil, explodiu ainda, nomeadamente em Adrianopla e em Tessalónica, uma revolta social dos antiaristocratas, incentivados pelo mégas dux Apocauco; nesta última cidade, a rebelião conduziu mesmo à formação de um governo de zelotes durante alguns anos (Ravegnani 2006 174). No final, foi de novo Cantacuzeno quem ganhou a guerra civil, tendo-se feito coroar coimperador em 1347; com ele, que governava como João VI mas em nome do legítimo basileús (João V Paleólogo), o hesicasmo tornou-se a doutrina oficial da Igreja bizantina, circunstância que alargou o fosso relativamente a Roma.

Nesta época, o velho império estava exangue e sofria constantes perdas territoriais: Kios (para os Genoveses), a Macedónia (com exceção de Tessalónica), o Epiro e a Tessália (para os Sérvios) e outras regiões. Bizâncio estava agora reduzida, para além da capital e dos seus subúrbios, à Trácia, às ilhas do norte do mar Egeu, a Tessalónica (cada vez mais isolada) e a uma parte do Peloponeso. Mau grado todos os esforços e reformas, o império entrou em colapso financeiro, ao ponto de a imperatriz Ana de Saboia decidir empenhar a Veneza as joias da Coroa, incluindo a baixela da corte, toda em chumbo e em terracota (Ravegnani 2006 174)! Para agravar a situação, em 1347, a Peste Negra chegava a Constantinopla... 
João Cantazueno tentou gerir o melhor possível as relações com as repúblicas mercantis italianas. Não foi nada fácil, dada a extrema rivalidade entre Veneza e Génova (que travaram uma batalha naval, de resultado indeciso, no Bósforo, em fevereiro de 1352); para mais, Cantacuzeno e João V tinham preferências distintas em matéria de alianças, e essa discórdia acabou por conduzir a uma nova guerra civil, aberta em 1352 e favorável a Cantacuzeno (e aos Genoveses), graças à intervenção dos Otomanos. Estes aproveitaram o embalo e, em 1354, invadiram a Europa, tendo tomado Galilopoli, no Helesponto, uma porta de entrada privilegiada no continente europeu! Vencido mas não convencido, João $\mathrm{V}$ aliou-se então a um corsário genovês, Francesco Gattiluso, a quem prometeu a ilha de Lesbos; juntos, promoveram a deposição de Cantacuzeno, em finais de 1354; o notável governante foi obrigado a tornar-se monge, mas ainda viveria durante cerca de três décadas, com grande participação na vida pública (aliás, os seus partidários mantiveram-se no poder na Moreia até 1380) e, sobretudo, com uma intervenção cultural relevante: Cantacuzeno compôs uma história dos acontecimentos do seu tempo que constitui uma fonte preciosa.

Ao assumir finalmente o poder como único governante, João $\mathrm{V}$ teve de enfrentar uma situação desesperada, em especial devido à ameaça dos Otomanos, que aproveitaram a morte do czar Estêvão Dusan para esfrangalhar o Império Sérvio (1355) e que, a partir de Galilopoli, começaram a submeter a Trácia; em 1359, os Otomanos surgiam pela primeira vez às portas de Constantinopla; depois, atacaram a Bulgária, tendo submetido Filipopolis em 1363. Dois anos mais tarde, o sultão Murad I fixava a sua capital em Adrianopla (em plena Trácia)! Com estes acontecimentos, todo o Ocidente se sentiu ameaçado e Bizâncio começou a ser vista na Europa com mais simpatia, por constituir a fronteira da cristandade contra os Turcos. Desde 1355, João V procurou uma aliança, acenando de novo 
com a submissão da Igreja bizantina a Roma, e começaram a ser concebidos planos para uma grande cruzada contra os Otomanos; mas só em 1365, graças aos esforços do papa de Avinhão, Urbano V (1362-1370), com o apoio do rei de Chipre (Pedro de Lusignan), se deu uma ofensiva cristã; esta acabou, todavia, por redundar em fracasso, com um ataque ao Egito e o saque de Alexandria. João V viajou para Buda, em busca de apoios, mas só o conde Amadeu de Saboia, primo do basileús, correspondeu, possibilitando a reconquista de Galilopoli, em 1366, e alguns outros sucessos contra os Turcos e os Búlgaros (incluindo a libertação do imperador, que havia sido aprisionado no seu regresso da Hungria).

Entre 1369 e 1371, João V viajou para Itália, em busca de salvação e disposto a tudo; em Roma, converteu-se ao catolicismo romano; a Veneza, ofereceu a cobiçada ilha de Ténedos (no Helesponto), em troca de ajuda militar, mas sem sucesso. Em 1371, os Turcos venceram estrondosamente os Sérvios em Maritsa e reduziram a Macedónia sérvia à vassalagem: Bulgária e Bizâncio foram gradualmente reduzidas a um estado de dependência formal dos Turcos, que exigiam tributos e fornecimento de tropas. Em 1387, Tessalónica tombou, após três anos de um duro cerco a Manuel Paleólogo (filho do imperador); no ano seguinte, os Otomanos afogaram em sangue a insurreição sérvia (apoiada pelos Búlgaros) nos Balcãs, ao vencerem a batalha de Kosovo Polje, em 15 de junho de 1389; o sultão Murad I até morreu no combate, mas o seu filho Bajazed I assegurou a vitória sobre o príncipe Lázaro da Sérvia e sobre os seus apoiantes nobres, que foram presos e executados; toda a Sérvia caiu então sob o domínio turco...

Entretanto, em Constantinopla, rebentara uma nova crise dinástica, com Andrónico IV (filho de João V), apoiado por um príncipe otomano, a promover uma conjura contra o pai e o sultão Murad I, em 1376. A conspiração foi duramente reprimida, mas Andrónico IV (1376-1379) conseguiu fugir da prisão e, com o apoio genovês 
e turco, tomou o poder; prendeu o pai, confiscou os bens dos Venezianos (cedendo Ténedos aos Genoveses) e restituiu Galilopoli aos Turcos. Governou na base de compromissos vários durante três anos, mas, em 1379, João V Paleólogo e o seu segundo filho, Manuel, depuseram-no com a ajuda de Veneza e dos Turcos, que os haviam retirado das masmorras.

A queda de Bizâncio estava cada vez mais iminente e o cenário era de completa desagregação do que restava do velho império. Em 1391, à morte do pai, Manuel II (1391-1425) subiu ao trono, numa altura em que a expansão otomana prosseguia imparável, sob a liderança de Bajazed I; em finais do século xıv, Bizâncio já só controlava Constantinopla e (de novo) a Moreia, que era governada por um déspota convertido em vassalo dos Turcos. Em 1393, os Otomanos submeteram a Bulgária e ameaçaram a Hungria, tendo ocupado também Tessalónica; dois anos mais tarde, a Valáquia tornou-se vassala dos Turcos e deu-se uma incursão militar na Moreia (Peloponeso); pelo meio, registou-se um bloqueio a Constantinopla, que apenas sobreviveu graças aos abastecimentos venezianos.

Neste cenário, o Ocidente tentou de novo organizar uma cruzada em defesa da cristandade; o seu promotor foi o rei Sigismundo da Hungria, o único Estado balcânico com recursos para tal empresa. Em Roma e em Avinhão, os papas Bonifácio IX e Bento XIII, respetivamente, deram o seu apoio ao projeto, o que permitiu concentrar perto de 100000 homens, na sua maioria húngaros, em Buda. No verão de 1396, o exército cruzado passou o rio Danúbio e foi cercar Nicópolis; porém, a 25 de setembro, Bajazed I apareceu para derrotar copiosamente as forças cristãs. Empolgado, no ano seguinte o sultão muçulmano ocupou Atenas e começou a expandir-se para a costa sul da Grécia, tomando Argos aos Venezianos.

Manuel II requereu desesperadamente o auxílio do Ocidente, mas só obteve promessas vagas. O rei de França, Carlos VI, ainda 
enviou uma pequena esquadra de 1000 homens, sob o comando do experiente marechal Boucicaut, que no final do verão de 1399 ajudou a romper o bloqueio turco a Constantinopla. Manuel II e o marechal viajaram então para a Europa (Itália, Paris, Londres), em busca dos apoios militares que rareavam: destas viagens, os resultados mais tangíveis foram até a nível cultural, com relevantes trocas de experiências e de informações entre eruditos gregos e ocidentais; por exemplo, Manuel Crisolora (aluno do erudito Demétrio Cidone) estabeleceu-se em Florença, onde ensinou o grego entre 1397 e 1400 (foi professor de Guarino Veronese), dando um importante impulso ao movimento humanístico europeu (Ravegnani 2006 182). Já politicamente, os reinos europeus pareciam mais empenhados na resolução das suas crises internas, agravadas pelos efeitos conjugados da Peste Negra, do Cisma de Avinhão e da Guerra dos Cem Anos. O contexto, definitivamente, em nada favorecia o antepenúltimo imperador de Bizâncio!

Quando tudo parecia ruir, porém, os Mongóis de Timurlenk (Tamerlão) derrotaram os Otomanos em Ancara (1402), prenderam Bajazed I e, assim, adiaram o fim de Bizâncio. É certo que os Mongóis se retiraram dois anos mais tarde, mas a luta pela sucessão no sultanato enfraqueceu os Otomanos até 1413; nesse ano, deu-se a ascensão de Mehmet I, e este novo sultão, por paradoxal que pareça, manteve com Bizâncio um relacionamento cordial até à sua morte, ocorrida em 1421. Manuel II pôde, assim, recuperar Tessalónica e o monte Athos, na Grécia, viu ser levantado o bloqueio a Constantinopla e ainda conseguiu aligeirar o tributo anual a pagar aos Otomanos.

Seguiram-se alguns anos de calma e até de vitalidade cultural, especialmente em Mistras (com o déspota Teodoro II Paleólogo e o humanista Jorge Gemisto Pletone), com um reflorescimento do helenismo, que contrasta de forma muito curiosa com a decadência do império. Como observa Ravegnani (2006 182), a Moreia tornou-se 
um viveiro de "grecidade" e expandiu-se por todo o Peloponeso (com exceção de algumas colónias venezianas, como Argo). Em 1432, a sujeição do principado latino de Acaia pôs fim à disputa franco-bizantina pelo Peloponeso, e o imperador ordenou então que se construísse um bastião defensivo (o Hexamilion) ao longo do istmo de Corinto.

Este radioso 'outono bizantino' terminou em 1421, quando o novo sultão otomano, Murad II (1421-1451), retomou a tradicional política antibizantina dos Turcos: os privilégios foram revogados, Constantinopla foi uma vez mais cercada (em 1422), o Hexamilion foi destruído (e o sul da Grécia saqueado, em 1423) e, enfim, Bizâncio foi constrangida a assinar uma paz humilhante, prestando de novo vassalagem aos Otomanos a partir de 1424. Seis anos mais tarde, ocorreu a queda de Tessalónica, a segunda cidade do império que os Venezianos (que tinham recebido a respetiva cedência em 1423) defenderam até ao fim.

Perante este quadro de renovadas aflições, o novo basileús, João VIII Paleólogo (1425-1448), efetuou - também ele - uma viagem ao Ocidente, em busca de apoio e jogando de novo a cartada da reunificação religiosa, acompanhado por muitos clérigos e monges e mesmo pelo patriarca José II. No Concílio de Ferrara-Florença, em 1438/1439, foi proclamada a união das duas Igrejas, mas em Bizâncio muitos populares e religiosos reagiram mal; as mais famosas exceções foram os bispos de Niceia, Bessarião, e de Kiev, Isidoro, que foram mesmo viver para Itália, onde se tornaram cardeais.

A Europa não foi totalmente indiferente aos últimos apelos bizantinos e, em 1443-1444, realizou-se a chamada Cruzada de Varna, de novo chefiada pelo rei da Hungria (neste caso Ladislau III), que conduziu um exército cruzado incluindo ainda o voivoda da Transilvânia (Hunyadi), o déspota da Sérvia (Brankovic) e um legado papal (Juliano Cesarini). Cerca de 25000 soldados (a que 
se juntaram pelo caminho perto de 8000 sérvios) cruzaram o rio Danúbio em inícios de outubro de 1443 e penetraram na Bulgária e na Trácia, obtendo muitos sucessos até que o inverno caiu e as operações pararam. Murad II viu-se em apuros, até porque teve de acudir na mesma altura a uma revolta na Ásia Menor, a uma insurreição na Albânia e à ofensiva de Constantino Paleólogo (o déspota bizantino da Moreia) sobre a Grécia central. Por isso, o sultão propôs uma trégua, negociando-se um armistício por dez anos, acordo esse que acabou depois por ser rejeitado pelos cristãos, com exceção do previdente déspota sérvio. Assim, o grosso dos cruzados avançou para o mar Negro e preparou-se para embarcar em navios venezianos, em Varna, para rumar a Constantinopla; no entanto, as operações foram mal coordenadas e um atraso nos movimentos dos Venezianos permitiu a Murad II transportar tropas asiáticas para o Bósforo. Por fim, a 10 de novembro de 1444 , as forças otomanas, que superavam na proporção de um para três as suas adversárias, infligiram aos cruzados a sua última derrota, perto da cidade de Varna (atual Bulgária); o rei Ladislau e o cardeal Cesarini morreram e poucos cristãos se salvaram...

Quatro anos mais tarde, o déspota da Moreia, Constantino XI Paleólogo (1448-1453), tornou-se o último basileús bizantino, tendo sido coroado em Mistras, perto de Esparta (e já não em Constantinopla). Todavia, já pouco ou nada poderia fazer pela causa do velho império, perante a cavalgada imparável dos Turcos; com a Moreia devastada desde 1446 por Murad II, restava, nas montanhas da Albânia, a resistência de Jorge Castriota "Scanderberg".

Em 1451, um novo e jovem sultão otomano, Mehmet II, "o Conquistador", percebeu que tinha chegado a hora de acabar com o que restava de Bizâncio, e que se resumia praticamente à capital: isolou Constantinopla, construiu no ponto mais estreito do Bósforo o castelo de Rumili-Hisar (que contracenava com a fortaleza 
de Anadolu Hisar, erguida por Bajazed I na margem asiática) e muniu-o de artilharia extremamente potente, capaz de impedir a aproximação de qualquer navio inimigo. Em começos de abril de 1453, teve início o cerco otomano a Constantinopla, com um exército que se estima reunisse 150000 homens e uma força tremenda de artilharia (incluindo um célebre canhão gigantesco fabricado em Adrianopla por um especialista húngaro e que foi transportado por 60 bois durante dois meses!). Do lado de dentro, a cidade-ícone era defendida por apenas 7000 homens, entre residentes, venezianos e sete centenas de mercenários genoveses comandados por João Justiniano Longo, que comandava as operações (voltaremos a este assunto na segunda parte deste volume).

O assalto começou a 12 de abril de 1453, por mar e por terra, e não se pode dizer que a resistência não tenha sido brava; porém, o bombardeamento foi-se intensificando e, a 26 de abril, Mehmet II começou a preparar a ofensiva final. No dia 28, fez-se em Constantinopla uma grande procissão, seguida de uma cerimónia religiosa: o destino estava traçado, mas muitos esperavam ainda um milagre. No dia 29 de maio, pelas três horas da madrugada, os Otomanos concretizaram o derradeiro assalto, com os janízaros (uma tropa de elite composta por jovens cristãos capturados em batalha, convertidos ao islão e treinados para a guerra desde criança) a conseguirem ultrapassar a muralha ao nascer do Sol. O comandante Longo, ferido, abandonou as operações, e o pânico generalizou-se; quanto ao último dos imperadores, Constantino XI, morreu dignamente em combate; algumas embarcações de venezianos, de genoveses ou de cretenses foram a tábua de salvação para uma parte dos cristãos que conseguiu sobreviver. Nos três dias seguintes, Constantinopla foi sujeita aos rigores da 'lei da espada', tendo sido brutalmente saqueada.

O Ocidente pouco tinha feito para salvar a maior cidade cristã do mundo, a qual forneceria aos Turcos uma ótima base de apoio 
para o seu assalto futuro à Europa (travado em 1529 e, de novo, em 1683, às portas de Viena). Desencantada com a união religiosa proclamada em Santa Sofia pouco antes do Natal de 1452, uma grande parte dos súbditos bizantinos resignou-se à submissão muçulmana, que não se estimava que pudesse ser pior do que a 'romana'... O ducado de Atenas tombou em 1456, a Moreia cairia em 1460 e Trebizonda no ano seguinte; já as colónias venezianas e genovesas, espalhadas pelo espaço imperial, resistiram um pouco mais à investida turca. Entretanto, muitos bizantinos refugiaram-se em Itália, entre os quais um número significativo de eruditos.

Terminava assim a história de Bizâncio. O Império Romano do Oriente deixou, todavia, uma herança significativa (Cheynet 2001 172):

i) do ponto de vista político, o seu legado foi assumido pelos Turcos, que necessitaram de um século (até ao apogeu, sob Solimão, "o Magnífico") para reconstituir o império da Antiguidade Tardia, centrado em Constantinopla, que voltaria a ser uma grande metrópole. Como no tempo de Bizâncio, a administração do Império Otomano organizou-se em torno da divisão entre Europa e Ásia (Anatólia). Os Gregos, os Sérvios, os Búlgaros e as outras nações conservaram a sua religião e as suas próprias leis, sob o olhar vigilante do sultão otomano, que acautelava o bem-estar dos seus povos. Foi também por isso que, no período recente da deslocação do Estado otomano (a partir dos inícios do século XIX), as nações grega, sérvia e búlgara puderam ressurgir;

ii) do ponto de vista espiritual, a herança bizantina foi reclamada por Moscovo, que se intitulou mesmo... a "terceira Roma"! Em 1472, o grão-duque Ivan III casou em segundas núpcias com Sofia Paleóloga, sobrinha do último 
basileús. O czar tornou a Igreja de Moscovo independente do patriarca de Constantinopla, cargo para o qual Mehmet II escolheu, aliás, um titular grego (Scholarios), mas claramente antiocidental. O monaquismo do Athos sobreviveu, e a Santa Montanha foi reedificada por cristãos dos Balcãs e da România. Nos séculos XV e XVI, os mosteiros ligados a Meteore (na Tessália) constituiriam um verdadeiro bastião da ortodoxia;

iii) do ponto de vista intelectual, a presença de muitos letrados orientais no Ocidente, a partir de 1453, reintroduziu na Europa o apreço pela língua grega e estimulou a grande curiosidade dos ocidentais pelos autores clássicos gregos. Em Veneza, que detinha as ilhas jónicas (como Creta ou Naxos), a única província da Grécia que escapava à autoridade otomana, os refugiados mantiveram um centro de helenismo bastante ativo.

Entretanto, o espírito de cruzada não tinha sido abolido: na corte dos reis de França, nos séculos xv e xvi, alguns gregos (da família Lascaris e de outras) forneciam informações preciosas sobre as capacidades militares do sultão e multiplicavam os conselhos para uma expedição a Constantinopla. O tempo do Império Bizantino, porém, tinha-se esgotado definitivamente...

\section{Em jeito de visita guiada}

Concluída a viagem pela história política do Império Bizantino, gostaríamos agora, para finalizar a primeira parte deste volume, de iluminar alguns aspetos da vida em Bizâncio que nos parecem especialmente relevantes. Selecionámos três e, sobre cada um deles, faremos uma pequena síntese. 


\subsection{A paisagem e a economia ${ }^{6}$ :}

A economia bizantina teve grandes oscilações ao longo do vasto período considerado, muitas delas provocadas por agentes externos: a peste, a varíola, as calamidades naturais (secas, pragas de gafanhotos, entre outras). Também a guerra e os movimentos de deslocação das populações afetaram significativamente a economia e a paisagem.

No período da Antiguidade Tardia, o mundo rural era a grande fonte de recursos. O imperador era o principal proprietário, seguido pela Igreja e pelos latifundiários (mas no Egito, por exemplo, só havia $10 \%$ de grandes proprietários, em contraste com os muitos cidadãos que dispunham de pequenas courelas); a escravatura rural entrou em recuo e não parece ter havido mudanças significativas, nem nos utensílios, nem nos métodos agrícolas. As principais culturas eram o trigo, a vinha e a oliveira (uma trilogia muito mediterrânica), mas com rendimentos muito variáveis, consoante as regiões; por exemplo, nas montanhas dos Balcãs produzia-se muito menos do que no vale do Egito. Esta agricultura produzia excedentes que alimentavam as grandes cidades, como Constantinopla, com meio milhão de habitantes no seu apogeu (ainda assim, muito abaixo de Bagdade, que tinha o dobro no século x), mas também havia lugar à criação de animais, sobretudo como forma de valorização das regiões montanhosas, florestais ou semiáridas, e até de cavalos de guerra (p. ex., nas coudelarias da Frígia). As mulas e os camelos eram utilizados para o transporte, os bovinos para a tração, o leite e a carne, enquanto as cabras, os carneiros e os porcos serviam para o consumo alimentar e para as artes têxteis. Havia algumas especializações, como os cereais ou o azeite, mas

\footnotetext{
6 Neste ponto, e salvo indicação em contrário, apoiar-nos-emos em Jean-Claude Cheynet, 2001.
} 
não existia monocultura, e algumas regiões, como o norte da Síria, alcançaram níveis elevados de prosperidade.

As reformas monetárias dos imperadores (como Anastácio I, 491518) revelam a intenção de se adaptar a uma economia de troca, com moedas regionais e um desenvolvimento interessante do artesanato: cerâmica para guardar o vinho e o azeite, com diversos tipos regionais de ânforas, e peças de louça, vidros sírios e lamparinas. Os basileîs empenharam-se na manutenção dos portos e das estradas comerciais, embora os portos mediterrânicos fossem agora mais pequenos (salvo o de Constantinopla), se bem que munidos de bons equipamentos (casos de Alexandria, Antioquia ou Cesareia da Palestina). A capital era o nó das grandes rotas comerciais, por ali circulando trigo egípcio, grãos africanos, azeite e vinho da Síria e da Palestina, entre outros produtos. Em matéria de exportações, elas faziam-se em grande quantidade da África bizantina para os Balcãs e a Gália, mas também para o Ocidente bárbaro, até à Bretanha; no entanto, era com o Oriente que as trocas incidindo sobre mercadorias de preço se revelavam mais ativas: a rota das Índias, pelo mar Vermelho, era utilizada para importar especiarias e incenso, mas também chegavam à Síria-Palestina caravanas oriundas da Pérsia; pelo reino cristão de Axum (atual Etiópia) chegavam os produtos africanos, como o marfim; Tiro, pelo seu lado, foi um grande centro de trânsito da seda bruta que vinha do Oriente, antes de os monges terem conseguido introduzir o bicho-da-seda no império, ao tempo de Justiniano. Portanto, no século vi, temos um comércio ainda animado e com uma forte presença do Estado, que possuía manufaturas que permitiam entregar armas aos soldados e formar ateliês têxteis, nomeadamente os do palácio imperial, onde se trabalhava a seda (em especial a de cor púrpura, um exclusivo do basileús).

Com a peste e a varíola de 560, a economia bizantina estremeceu e a população diminuiu de forma significativa. O Mediterrâneo permaneceu aberto às trocas, todavia estas eram agora menos intensas. 
Com as vitórias dos Árabes no mar, a partir de meados do século viI, houve uma redução drástica da atividade marítima, mas, ao mesmo tempo, a recessão demográfica também tornou menos necessário o transporte de géneros alimentares a longa distância. Muitas cidades reduziram-se a acampamentos-refúgio, com exceção daquelas que ficavam fora das rotas de invasão. Ainda assim, nas províncias sob dominação árabe, preservou-se um certo dinamismo económico.

Do ponto de vista fiscal, o Império Bizantino caracterizou-se por uma taxação regular e por uma moeda de ouro forte (ao contrário do que sucedia no Ocidente). Não se sabe bem se os impostos eram pagos em moeda ou em géneros, mas é seguro que, com a reconquista macedónica do século $\mathrm{x}$, a pressão fiscal do Estado aumentou de forma significativa, de modo a garantir a existência de um exército numeroso, um dos grandes segredos da sobrevivência do império - sob Basílio II (963-1025), a máquina fiscal bizantina atingiu a sua maior eficácia, alcançando os 3000000 de nomísmata (o nomisma era uma moeda de ouro muito forte); havia uma capitação sobre as pessoas, outra sobre as transações comerciais e, ainda, uma série de taxas miúdas; os recursos estavam adaptados às despesas correntes, mas situações excecionais podiam provocar a cobrança de impostos adicionais. Todos os impostos estavam organizados por províncias, e pagar pelo vizinho faltoso dava direito a cultivar as suas terras; já os grandes domínios eram registados à parte, sendo toda a informação centralizada no sékrēton do génikon (o departamento da administração fiscal), em Constantinopla. Segundo Cheynet (2001 80), este sistema permitia ao Estado contar com rendimentos bastante estáveis, estimando-se que a parte de rendimentos de um camponês efetivamente taxada oscilasse entre um quinto e um quarto da sua produção, o que parece bastante razoável. Ao longo do século XI, o fisco deixou de vender as terras que lhe chegavam por diversas razões (fuga, conquista, arresto) e tornou-se ele próprio um grande proprietário, 
cobrando não só o imposto como uma renda: esta evolução esteve na origem da técnica fiscal da prónoia, a que já fizemos referência e que transferia para os beneficiários um direito fiscal.

Não é possível afirmar com precisão se, depois das calamidades sofridas (recorde-se que a recidiva da peste, em 747 , reduziu Constantinopla a menos de 100000 habitantes), o Império Bizantino recuperou (ou não) o nível demográfico da Antiguidade Tardia. Mas sabe-se que os basileîs procuraram instalar as populações recém-chegadas nas terras desertas; os Eslavos foram quem mais contribuiu para esta política, mas nem todas as deslocações se fizeram da Europa para a Ásia: por exemplo, os Isaurianos vitoriosos trouxeram muitos prisioneiros da Síria, e a Trácia foi reforçada com famílias arménias.

Certo é que a exploração familiar predominou, sobretudo numa fase inicial, tendo desaparecido a escravatura rural (os escravos que subsistiram eram essencialmente domésticos). A par das pequenas explorações, havia grandes domínios, como sabemos por uma fonte preciosa da primeira metade do século rx: a Vida de São Filareto, "o Misericordioso", um rico e generoso proprietário da Paflagónia, escrita pelo seu neto Niketas:

diz ele que Filareto (que teve uma neta, Maria, que casou com Constantino VI e se tornou augusta) "era muito rico e tinha bastantes animais: 600 cabeças de gado, uma centena de juntas de bois, 800 éguas nas pastagens, 80 cavalos e mulas de sela e 12000 ovelhas; Filareto tinha ainda 48 quintas com terra em quantidade, todas separadas, muito lindas e de grande valor, pois em frente de cada uma delas estava um poço abundante, vindo do cume de um morro e capaz de irrigar tudo aquilo de que precisasse. E tinha muitos escravos e possessões" (ed. L. Rydden, 1, p. 61). 
A partir do século ix, houve um claro movimento de concentração de terras, que quase levaria ao desaparecimento da pequena propriedade familiar sob a dinastia dos Comnenos. Como já vimos, nos séculos x e xi, alguns imperadores (como Romano I Lecapeno, Constantino VII ou Basílio II) tentaram travar este processo, proibindo aos grandes a compra de terras aos mais desfavorecidos e instituindo regras como a do allēléngyon (imposto fundiário que atingia os proprietários ricos, solidários com os seus pobres vizinhos em incumprimento, sem com isso beneficiarem do direito de precedência na compra) mas perderam esta batalha, embora tivessem tirado também algum partido fiscal disso. Aos poucos, as "terras estratióticas" foram desaparecendo e começou a notar-se alguma tendência para a colocação dos pequenos camponeses sob a dependência de grandes proprietários: os pároikoi, além do imposto normal, pagavam um censo (o paktón), mas não podiam ser expulsos pelos terratenentes; em contrapartida, ficavam obrigados a permanecer na sua terra, sem por isso se tornarem servos, já que, se encontrassem um substituto, poderiam partir. A força de trabalho e a superfície das terras era, entretanto, aquilo que diferenciava verdadeiramente a população camponesa e a inscrevia em categorias fiscais distintas: o zeugáratos tinha uma junta de bois completa e mantinha uma quinta de cinco a dez hectares, em média; o boïdatos possuía um único boi e associava-se a um colega para constituir uma junta; e o pezós ou aktémōn não tinha nem bens nem animais, mas podia alugar os seus serviços e ocupar-se do artesanato ou dos transportes a dorso de asno.

Também na época médio-bizantina parece ter havido escassa inovação técnica, com os instrumentos a evoluírem muito pouco: manteve-se o arado, adequado aos solos mediterrânicos, leves e macios; os instrumentos de ferro estavam já bastante difundidos, mas predominava uma utensilagem manual: enxada para completar os arroteamentos, pá, foicinha para a ceifa e outra. Nos Balcãs, 
a agricultura evoluiu relativamente pouco até à Primeira Guerra Mundial, também porque se tratava de uma lavoura muito virada para a autossuficiência. Há, no entanto, notícia de canais de rega, de moinhos de água, do aperfeiçoamento das técnicas de prensagem das uvas e das azeitonas, de seleção dos cereais, de difusão do trigo duro e do cultivo de leguminosas (ervilhas, favas e lentilhas) nos pousios. No século $\mathrm{x}$, as propriedades monásticas sentiram grandes dificuldades de capitais, mas na centúria seguinte foi instituído o regime do "caristicariado", pelo qual alguns notáveis laicos puderam colocar o seu dinheiro ao serviço da valorização dos domínios eclesiásticos, recebendo os eventuais excedentes dos rendimentos assim gerados, depois de providos os monges (Cheynet 2001 95). Em consequência dos arroteamentos, atestados pelos sinais de renovação urbana, surgiram novos lugarejos e mais mosteiros; no século xiı, sabemos que Bizâncio exportava trigo, apesar do aumento populacional.

A comunidade aldeã permaneceu sempre como um elemento nuclear muito forte. Em cada propriedade, as quintas costumavam estar agrupadas ao centro, empoleiradas num sítio com boas condições defensivas, no sopé das colinas ou perto dos rios. As casas camponesas eram ainda bastante frustes: muitas delas eram de madeira e possuíam um mobiliário pobre. Havia jardins, pomares e vinhas, protegidas por paliçadas e com as outras culturas à volta; nas periferias, existiam as terras baldias e os bosques. Cheynet (2001 96) lembra que, na Macedónia do século xı, o que havia era "uma paisagem de terras arborizadas e inexploradas, rompida todos os cinco ou seis quilómetros por uma clareira aldeã”. Os cereais continuaram a predominar, sendo metade trigo e o restante cevada e aveia. Utilizava-se o afolhamento bienal, com as leguminosas a serem utilizadas para suplemento de calorias, mas também para enriquecimento das terras em azoto. Quanto ao rendimento agrícola, estima-se que oscilasse entre 1:3 e 1:5 (grãos de 
trigo); neste último caso, já se gerariam excedentes. A vinha estava presente em todo o lado, mas a qualidade do produto era medíocre, apesar de alguns bons vinhos regionais, surgidos já nos finais da Idade Média (caso da malvasia da Monemvásia, no Peloponeso). É interessante realçar a presença frequente de jardins de 200 a 400 metros quadrados para cultivo de legumes (couves, alhos-porros, cenouras, alhos, pepinos) e de boas cinturas hortícolas à volta das cidades. Nas regiões mais áridas, escarpadas ou frias, continuou a recorrer-se à criação de gado; evoquem-se os grandes rebanhos de criadores especializados, como os Valáquios dos Balcãs, ou a criação de imensos cavalos no semiárido planalto da Anatólia.

De uma forma geral, pode dizer-se que a condição do camponês não era nem luxuosa nem miserável, mas estava sempre sujeita aos efeitos das guerras e das calamidades naturais, que podiam causar anos consecutivos de penúria. A alimentação camponesa parece ter sido bastante frugal: à base de trigo, completado com produtos da horta, da vinha ou da criação animal; nas regiões de pastorícia, a carne e o queijo eram muito importantes; as muitas colmeias permitiam também a produção de adoçante, sob a forma de mel.

A intensificação das relações com as grandes cidades mercantis italianas, a partir dos Comnenos (desde 1081), animou as trocas comerciais e estimulou o renascimento urbano. Nenhuma cidade igualava Constantinopla, mas Tessalónica, Éfeso ou Trebizonda podem ter atingido os 30000 a 40000 habitantes (Kaplan 1991 56). Na capital, vendiam-se, de forma muito liberal, produtos de todas as regiões e instalaram-se ofícios e lojas de mesteirais, com regras rigorosas de abertura e de funcionamento, que implicavam um exame prévio e a validação pelo éparchos. Em Constantinopla, havia padarias, mercearias, peixarias, tabernas e talhos, e, na zona do Grande Palácio, vendiam-se produtos de luxo, como metais preciosos, sedas e perfumes. 
Já sabemos que os Italianos dispuseram de bairros novos e de grandes privilégios para negociar em Constantinopla; resta saber se isso acarretou a decadência económica de Bizâncio. Segundo Cheynet (2001 106), até à conquista cruzada de 1204 tal não deve ter acontecido, porque a perda de receitas do Tesouro foi modesta, porque os mercadores orientais exportavam trigo e produtos de luxo que estimulavam a economia e porque os grandes proprietários fundiários e os artesãos de Tebas e de Corinto se achavam beneficiados. Em contrapartida, os mercadores bizantinos ficavam em minoria no seu próprio mercado, o que, a prazo, causaria muitos problemas (recorde-se o massacre dos Latinos, em 1182). Se é seguro que alguns comerciantes reuniram grandes fortunas, que lhes permitiram até ambicionar integrar a hierarquia da corte, não é menos verdade que os instrumentos de crédito estavam ainda pouco desenvolvidos: taxas de juro altas, sede de numerário, por exemplo. Já nas províncias, houve benefícios claros do desenvolvimento económico, com um artesanato ativo no século XII a atrair mercadores distantes (incluindo portugueses) a Tessalónica (sobretudo por ocasião da feira de São Demétrio) e a outras cidades, como Corinto e Tebas, onde se produziam tecidos de luxo para os mercadores italianos. Na Ásia Menor, as cidades de Antioquia, Melitena, Teodosiopólis, Erzerum e Trebizonda asseguravam o controlo das rotas de caravanas; na primeira daquelas cidades, havia mesmo mercadores de todo o Oriente, para além dos latinos; entre a classe mercantil de Antioquia, contavam-se muitas minorias religiosas, como Arménios e, sobretudo, Sírios, lembrando-nos a riqueza escondida dessas cidades do Oriente, que também impressionavam pelo contraste entre os bairros ricos e os quarteirões miseráveis que existiam em cada uma delas (Kaplan 1991 81). Mas claro que, após a conquista turca de 1453, o comércio, de uma forma geral, sofreu uma perturbação durante algumas décadas. 


\subsection{Constantinopla, Santa Sofia e o Grande Palácio7:}

Constantinopla foi concebida como uma "segunda Roma", de tal modo que foi também organizada em 14 secções urbanas, distribuídas por sete colinas (a última, do lado sul, praticamente não se distingue na paisagem, sendo meramente simbólica). O pequeno ribeiro do Lykos, que corre para o mar de Mármara, ocupou, neste imaginário, o lugar do sumptuoso rio Tibre.

Já falámos, no início deste trabalho, sobre as muralhas de Constantinopla, que os sismos obrigaram a reconstruir e que muito devem a Constantino e a Teodósio II. Por detrás dessas muralhas, sobressaía a massa dos grandes edifícios públicos, em especial o Grande Palácio, o Hipódromo e a Igreja de Santa Sofia, cuja cúpula dominava as de todos os outros edifícios religiosos. Os edifícios principais abriam para uma grande praça, o Augustéon, que representava o centro da cidade: do lado oriental, ficava o edifício do Senado, coroado por uma cúpula e antecedido por um pórtico; o revestimento de mármore branco exprimia o seu valor simbólico, apesar da desvalorização progressiva deste órgão de soberania a partir dos Heraclianos (desde 610); por trás, ficava o Grande Palácio, que abria para o Augustéon através de uma grande porta de bronze, a Chalkê. No século vi, foi aqui colocada a imagem de Cristo, em vez da de Constantino, mas Leão III, "o Isauriano" (717-741), ao abrir a época iconoclasta, mandou-a retirar. A sul da praça do Augustéon ficava o Hipódromo, de que também já falámos com algum pormenor; era o centro da vida política de Constantinopla e serviu para variadas funções, dos jogos às proclamações imperiais, passando pelas execuções e outras sevícias públicas (p. ex., em 766, por ocasião da crise iconoclástica, muitos

\footnotetext{
7 Seguiremos, neste ponto, Kaplan 1991 (para a descrição da cidade) e Ravegnani 2008 (para o Grande Palácio).
} 
monges e monjas foram obrigados a percorrer a pista desprovidos dos seus hábitos e alinhados em pares, com um homem e uma mulher de mãos dadas...).

Do outro lado da praça, elevava-se a grande Igreja de Santa Sofia, obra impressionante dos arquitetos Antémio de Trales e Isidoro de Mileto, que a reconstruíram depois da revolta Níka de 532. Este templo conserva a planta cristã herdada das basílicas romanas, mas está encimado por uma cúpula fabulosa que representa a esfera do reino de Deus. Como esta semiesfera tem 61 metros de altura e coroa um templo de planta retangular, foi necessário garantir um suporte sólido, por meio de pilares espessos, de contrafortes, de arcobotantes, de abóbadas e de semicúpulas. O edifício tem uma massa imensa e, quando se transpõe o nártex e se entra na nave, o olhar do visitante é instintivamente desviado para o alto, para a cúpula e para a figura de Cristo que a decora; os jogos de luz ajudam a imprimir um ambiente único de majestade e de elevação divina ao interior do templo.

A principal artéria de Constantinopla era a Mésē, que conduzia desde a praça do Augustéon até à Porta de Ouro, uma das entradas principais da cidade. Era uma avenida monumental e de grande animação comercial, bordejada de pórticos, ao fundo dos quais se abriam as lojas; aqui e ali, surgiam diversos foros (p. ex., de Constantino, de Teodósio, do Boi, de Arcádio), definidos por praças circulares ou retangulares. As outras artérias importantes que faziam a ligação dos setores leste e oeste da capital organizavam-se segundo o mesmo modelo; já as vias secundárias eram bastante estreitas e de traçado inseguro; as que tinham orientação norte-sul, segundo a boa tradição do quadriculado romano, em declive, assumiam por vezes a forma de escadarias; nestes acesos secundários, a circulação era mais difícil.

A aristocracia de Constantinopla possuía numerosos palácios imponentes, isolados e com jardins interiores sumptuosos ou com 
pátios bordejados por pórticos e ligados por galerias; nestes palácios, havia grandes salas para receções sociais, com todas as comodidades, a começar pelos banhos. Já os alojamentos das classes populares eram sombrios e desconfortáveis: geralmente, tinham uma oficina no rés do chão e a casa de morada no piso imediatamente acima. Os imóveis coletivos eram ainda raros, pois, apesar das grandes cisternas alimentadas por uma rede de aquedutos que iam buscar a água à Trácia, predominava ainda a figura do transportador de água. Já havia esgotos, mas subsistiam as dificuldades de eliminação dos dejetos, muitas vezes ainda feita diretamente para a rua. Como em muitas cidades do império que cresceram demasiado depressa, era grande o contraste entre um centro rico e uns arredores pobres.

Uma característica interessante de Constantinopla era a diversidade dos seus bairros, cujos nomes adotavam por vezes o da profissão que aí predominava, das suas cores, dos seus barulhos ou dos seus odores: perto de Santa Sofia, do lado poente, ficava o ruidoso bairro dos caldeireiros; mais à frente, sobre a Mésē, o dos ourives, e a seguir o dos aromas deliciosos dos perfumistas. Em toda a cidade havia padarias, sobretudo na Mésē, entre os foros de Constantino e de Teodósio. Com frequência, os bairros tomavam os nomes de grandes personagens que aí tinham o seu palácio: tà Eugeníou, tà Rouphíniou, tà Próbou, tà Olympiou, por exemplo (Kaplan 1991 56-69).

A par de Santa Sofia, o edifício mais importante era o Grande Palácio, ou Palácio Sacro, composto por uma série de construções, pátios, terraços e jardins situados entre o Augustéon e o mar de Mármara, no extremo oriental da cidade. Deve-se a Constantino a construção do núcleo original, que foi sendo ampliado ao longo dos séculos. Nos finais do século XI, o Grande Palácio começou a ceder o seu lugar ao Palácio de Blachernes, preferido pelos Comnenos, que ali ergueram esplêndidas habitações. Quando os 
Turcos tomaram Constantinopla, em 1453, o Grande Palácio já estava em ruína e, mais tarde, ainda se construiu por cima desses destroços...

Entrava-se no Grande Palácio pelo Augustéon e, depois de transpor a Chalkê (onde havia muitas estátuas de grandes personagens da história bizantina), acedia-se a um edifício de planta retangular, com uma grande cúpula central em forma de ovo (o Oaton) e duas abóbadas menores. As paredes interiores estavam decoradas com mármores policromáticos, e os tetos com mosaicos alusivos aos triunfos de Justiniano. Ultrapassando o quarteirão da guarda imperial, acedia-se à parte mais interna do palácio, com o Triclínio dos XIX Leitos (a sala de banquetes), a Igreja do Senhor e o Consistório. No conjunto de edifícios do Grande Palácio, figuravam também a Sakelle (arquivo e depósito do Tesouro), o Palácio de Dafne, o Augusteus (sala de representação, onde foram coroadas muitas imperatrizes), a Igreja de Santo Estêvão (fundada em 428, por Pulquéria, com relíquias preciosas) e o Octágōnon (a sala octogonal). A Igreja de Santo Estêvão ligava-se ao Káthisma, composto por três pisos e com vários apartamentos, para além da já citada tribuna onde o imperador podia seguir os jogos do Hipódromo. No século Ix, Teófilo acrescentou a este complexo outros edifícios, como o Tríkonchos (com teto dourado e três absides) ou o Sígma (munido de uma arcada semicircular).

A Justino II (565-578) devia-se o centro da vida pública do palácio: o Chrysotríklinos, uma sala de ouro com forma octogonal e uma cúpula semelhante à da Basílica de São Vital de Ravenna; o trono estava posicionado na abside, debaixo de um mosaico que representava Cristo no trono: ou seja, estabelecia-se uma relação implícita entre a corte celeste e a corte terrestre. A norte do Chrysotríklinos ficavam o Lausiakós (também devido a Justino II, mas com mosaicos de Teófilo), o Trípeton (que funcionava como um vestíbulo do Chrysotríklinos), o Relógio e o Kenoúrgion (uma 
sala em forma de basílica, da época do imperador Basílio I, decorada com mosaicos de fundo dourado representando membros da família imperial). Na parte sul do palácio, havia três igrejas contíguas: Teótoco de Faro, São Demétrio e Santo Elias, a que Basílio I (867-886) acrescentou a Néa (ou seja, a nova, a mais rica e a mais esplendorosa de todas).

A norte do complexo palatino encontrava-se a Magnaura, uma sala de representação, talvez de Constantino I, muito importante para os cerimoniais; tratava-se de uma basílica em três naves e com três absides; no centro, estava instalado o trono de Salomão, conforme a descrição bíblica que consta do primeiro Livro de Reis: "Do mesmo modo, o rei fez um grande trono de marfim que revestiu de ouro puro. $\mathrm{O}$ trono tinha seis degraus; no espaldar havia seis cabeças de vitelo; o assento tinha dois braços laterais, em cujos flancos se erguiam dois leões. Doze [outros] leões irrompiam daqui e dali, sobre degraus; não existia nada semelhante em nenhum reino" (citado por Ravegnani 2008 106). Eis aqui bem materializada a ideia do imperador "eleito por Deus", com o trono disposto como o altar numa igreja: o basileús era, de facto, o novo Salomão! Mas a Magnaura incluía ainda, na parte contrária à fachada, uma zona arborizada, provavelmente uma alameda com árvores de um lado e do outro, e servia para diversos fins: "receção aos embaixadores e personagens ilustres, assembleias solenes, sede da universidade, corte de justiça e até, ocasionalmente, habitação dos soberanos" (Ravegnani 2008 106).

Mais isolados, ao longo da costa do mar de Mármara, ficavam a Casa de Hormisdas, o porto de Boukoléōn, com um conjunto de mármore visível do porto e representando um leão a atacar um touro (incluía ainda um palácio do tempo de Teodósio II), e, possivelmente, a Porphýra, de que fala Ana Comnena na Alexíade: trata-se de uma divisão quadrada, com cobertura piramidal, pavimento de mármore e paredes em púrpura vermelha com pontos brancos; a tradição diz que era aí que, desde Constantino, 
as imperatrizes davam à luz os filhos, por isso chamados "porfirogenetas". Entre aqueles três edifícios e o complexo palatino estava o Tzykanistếrion, um estádio para divertimento da corte, onde se jogava o tzykánion, um jogo do tipo do polo, oriundo da Pérsia. Contíguo ao palácio, ficava o Hipódromo, que já descrevemos e de que restam vestígios na atual praça de Atmeydani, em Istambul (obelisco e colunas).

Em síntese, o Grande Palácio constituía uma pequena cidade e contava com uma guarda própria de 10000 homens. Um grande número de dependentes assegurava os serviços palatinos, com realce para os eunucos (a "multidão dos homens castos"), de quem Coripo diz terem carta-branca para aceder a serviços decisivos nos lugares sacros, à mesa, no policiamento da casa, nos aposentos sagrados, no vestiário e noutros espaços reservados. Constantino VII diz que eles eram tantos que pareciam moscas num estábulo durante o verão, apesar das leis que proibiam a castração - uma sujeição cruel e a que sobreviviam menos de três em cada noventa homens (Ravegnani 2008 108-109)! Os eunucos cresceram muito com a imperatriz Irene (797-802), e as cerimónias dos séculos Ix e $\mathrm{x}$ mostram que eram um grupo organizado hierarquicamente. Ao que parece - e já que as leis bizantinas, nomeadamente de Leão I (457-474), proibiam a venda de eunucos 'romanos' no império -, eram recrutados entre 'bárbaros' da Pérsia, da Arménia ou do Cáucaso; na época de Justiniano I, provinham sobretudo do reino pagão dos Abasgi (entre o mar Negro e o Cáucaso); Procópio conta que os dois reis locais raptavam as crianças às famílias para as castrarem e venderem mais caro no Império Bizantino; escolhiam as mais belas e matavam os pais, para evitarem futuras vinganças.

Os eunucos eram muito requisitados pela corte e pela aristocracia bizantinas, sendo mais caros do que os escravos normais; o seu preço variava conforme a sua idade e aquilo que sabiam fazer. Justiniano procurou, sem sucesso, travar esta situação com 
leis severas, como numa Novella de 558, em que prevê a pena de mutilação e o confisco de bens (ou a deportação, caso fossem mulheres a prevaricar). Atribuía-se aos eunucos a guarda do gineceu e muitos outros serviços palatinos; eram também essenciais nas cerimónias: como anjos, rodeavam o soberano terrestre. Tiveram ainda importantes funções públicas, religiosas (incluindo alguns patriarcas) e até militares, e o seu alto estatuto na corte era bem evidente: enquanto cubicularii (ou camareiros), integravam o sacrum cubiculum imperial; tal como outros funcionários não eunucos (p. ex., os silentiarii), estavam sob a autoridade do praepositus sacri cubiculum (igualmente um eunuco), com competências financeiras e outras. Se fossem escravos, obtinham a liberdade ao entrarem ao serviço do imperador. O seu chefe era equiparado aos mais altos funcionários públicos, com o título de illustris; quando aposentados, entravam para o Senado (Ravegnani 2008 109-110).

\subsection{O espetáculo do poder :}

Valeria a pena ser imperador de Bizâncio?... A resposta não é fácil: de um lado, o fascínio do poder, o enorme prestígio do cargo e a inserção num mundo de etiquetas e de cerimoniais que ainda hoje nos parece irreal; do outro, o risco da função: entre Zenão (474-491) e Constantino XI (1449-1453), Bizâncio teve cerca de 80 imperadores e coimperadores, dos quais quase $40 \%$ foram depostos; destes, uma dezena e meia foi assassinada, e muitos outros foram objeto de mutilações gravíssimas, para não poderem voltar a exercer o cargo: olhos arrancados e narizes cortados, na maior parte dos casos; os destronados mais felizes foram forçados

8 Neste ponto, seguiremos sobretudo Ravegnani, 2008, passim. 
a tornar-se monges ou exilados; há ainda alguns casos (raros) de imperadores que morreram na guerra (como Nicéforo I).

Qualquer que seja a resposta do leitor, falaremos sobretudo da parte boa do cargo... Como já vimos ao discutir o principado de Justiniano, a corte bizantina celebrava uma autoridade absoluta e desejada por Deus. Os relatos dos muitos escritores que se referem à vida deslumbrante da corte de Constantinopla (Procópio de Cesareia, Pedro Patrício, Coripo, Miguel Pselo, Ana Comnena, Constantino VII Porfirogeneta, Filoteu, Agapito de Santa Sofia, o Pseudo-Codino, entre muitos outros) deixam claro que Deus era a fonte da legitimidade do poder imperial e que o basileús dei Romani era um intermediário entre o céu e a terra, uma espécie de $13 .^{\circ}$ apóstolo. Por isso, o palácio era um lugar sagrado, um espelho da harmonia do mundo, construída à imagem e semelhança da harmonia celestial. O céu era o modelo da perfeição e o governo do bom imperador imitava Deus, para depois ser imitado pelos súbditos: portanto, o palácio (quer o Grande Palácio quer, a partir dos Comnenos, o Palácio de Blachernes) deveria ser um espaço esplendoroso, capaz de reproduzir na terra a corte celeste. Já vimos que, no Chrysotríklinos, o cadeiral do soberano surgia sob uma imagem de Cristo no trono; e que, na Magnaura, o basileús se sentava num trono construído segundo o modelo bíblico do de Salomão. No fundo, o rei dos céus enviara o imperador para que ele o representasse na terra; este devia, por isso, ser virtuoso, capaz e fisicamente perfeito, razão por que os mutilados (incluindo os eunucos), não correspondendo ao cânone, não podiam aspirar ao poder supremo.

Tudo no palácio funcionava de maneira muito formal, segundo ritos, gestos e fórmulas muito expressivos e rigorosos. Por exemplo, o silêncio era deveras importante na presença do soberano, que agia como um ídolo impassível, servido por eunucos em vestes cerimoniais, como se fossem anjos, e que conduziam as operações. 
O basileús não pisava o mesmo chão dos outros: caminhava sobre tapetes de púrpura ou sobre placas de pórfiro, e só ele podia utilizar os sapatos cor de púrpura! Quem recebia um dom do imperador, devia levá-lo consigo e escondê-lo na dobra do manto, para preservar a sua sacralidade. Nos cerimoniais da corte, a marca religiosa era forte, todos tinham lugares próprios e o imperador não falava, comunicando por gestos com os eunucos. A música tinha também um papel importantíssimo, por exemplo nas cerimónias de aclamação do novo basileús. Apesar das reservas do clero, a adoração das imagens imperiais nunca foi abolida: enquanto cópia da corte celeste, a corte terrena devia suscitar a devoção. Vestes cerimoniais de tipo litúrgico, aclamações rítmicas, velas e incensos, cânticos de exaltação do soberano, tudo isso tinha o seu espaço e o seu papel na fascinante vida cortesã bizantina.

Como vimos, não havia em Bizâncio, tal como não houvera em Roma, regras precisas de sucessão no trono: o problema era regulado pelo costume e pelas circunstâncias do momento. Em teoria, a dignidade imperial era eletiva, cabendo ao Senado, aos grandes dignitários do Estado, ao exército e ao povo uma palavra decisiva na escolha do novo soberano. No entanto, progressivamente, foi-se acentuando uma tendência para a transmissão hereditária do poder, o que levou à constituição de dinastias. A partir de Miguel II Amoriano (820-829), este novo modelo sucessório ficou praticamente consolidado, seguindo-se sete dinastias quase sem interrupção: os Amorianos, os Macedónios, os Ducas (estes por apenas três décadas), os Comnenos, os Anjos (ou Ângelos), os Lascárides de Niceia e os Paleólogos. O legitimismo foi-se enraizando na mentalidade popular e o trono tornou-se um bem de família, com o poder a assumir frequentemente uma forma colegial: um imperador, a que se associava(m) um ou mais coimperadores, geralmente seus familiares (de raiz ou por via de casamentos urdidos na ocasião). A partir dos Macedónios (867-1056), enfatizou-se 
o conceito de "porfirogenetas", para referenciar aqueles que, tendo nascido na púrpura (isto é, na sala Porphýra), do ventre de uma augusta ou basílissa, transportavam consigo a garantia de serem membros da família imperial.

Subidos ao trono, os imperadores de Bizâncio, ainda que devedores de contas apenas ao poder divino, deviam respeitar a Igreja e, de preferência, as leis que eles próprios produziam. Teoricamente, não havia outros limites ao seu poder, mas não restam dúvidas de que existiram diversos contrapesos, que condicionaram fortemente o exercício concreto da governação: o poder da aristocracia fundiária; a força das fações do Hipódromo (os Verdes e os Azuis, expressão do sentimento do povo de Constantinopla); o monaquismo; os patriarcas (em particular o da capital); e as forças armadas (em especial os estrategos dos grandes témata). Em última análise, recorria-se à usurpação ("a autocracia imperial era, assim, temperada pela usurpação": Kaplan, 1991 32), ainda que, cada vez mais, com a preocupação de não se suplantar a dinastia legítima, ou seja, mantendo nominalmente em funções o imperador (ou a imperatriz) no poder: recorde-se o regresso de Zoé, sobrinha de Basílio II, em 1042, sob forte aclamação popular. Isto mostra que, na etapa médio-bizantina, pelo menos desde os meados do século Ix, era possível aceitar uma sucessão por via do matrimónio ou da adoção, por muito forçados que fossem, mas já não a violação do princípio da legitimidade dinástica (Ravegnani 2008 65).

Quanto ao princípio da primogenitura, funcionou como regra geral, sobretudo a partir da fase de afirmação clara das dinastias; no entanto, não havia mecanismos rígidos, e o princípio da colegialidade que referimos não devia esmagar a vontade própria do principal soberano; foi por isso que João II Comneno, em 1143, pôde indicar como sucessor, não o seu primogénito, mas um filho segundo: Manuel I. Por fim, devemos salientar 
o papel dos conselhos de regência e das imperatrizes nos momentos de algum 'vazio de poder', criados pela ascensão ao trono de príncipes muito jovens; algumas imperatrizes-mãe, como a cruel Irene (797-802), aproveitaram bastante bem esses períodos de transição, quase sempre associados a situações de grave instabilidade.

A partir dos Paleólogos (1259/61-1453), a última e também a mais longa de todas as dinastias bizantinas, nota-se claramente uma tendência para o exacerbamento das lutas de poder no seio da própria família imperial. Se os Comnenos tinham valorizado os laços de sangue que uniam o basileús aos seus colaboradores mais próximos, já os Paleólogos experimentaram uma deriva quase suicida para a guerra interna e para a faida entre famílias. Curiosamente, isto aconteceu no exato momento em que o território do império se reduzia de modo substancial.

As cerimónias solenes de investidura imperial tinham origem romana, mas foram enriquecidas com o tempo e, a partir do século vII, predominou nelas o aspeto religioso. Antes disso, a cerimónia da coroação comportava três grandes momentos:

i) o rito militar, com o cerimonial do levantamento no escudo, segundo uma tradição de origem germânica que envolvia a atribuição do torque (o colar de tipo celta) e da coroa, traduzindo a delegação de uma autoridade de comando;

ii) a coroação propriamente dita, com a receção do diadema, a ida a Santa Sofia, a deposição da coroa no altar, a pregação pelo patriarca e, novamente, a coroação do basileús;

iii) a proclamação em espaço público, com aclamação pelos soldados e pelo povo, promessas de bom governo, entrega de donativos às tropas, uma procissão a Santa Sofia e um banquete solene espampanante. 
Com o tempo, o rito militar tornou-se quase residual, e a coroação pelo patriarca converteu-se no momento principal da cerimónia; dada a relevância das disputas religiosas em Bizâncio, foi, aliás, exigido um juramento de ortodoxia a muitos basileîs (como a Miguel I ou a Leão V), o qual seria substituído, no século Ix, por um credo segundo os cânones dos concílios eclesiásticos. Para o novo imperador, a caução religiosa era imprescindível, e reforçou-se com a introdução do rito da unção sagrada com o crisma (unguento de nardo consagrado), talvez a partir do século ix e em Santa Sofia, com o patriarca de Constantinopla a traçar uma cruz sobre a cabeça do novo imperador; este rito tinha o valor do batismo, cancelando os pecados anteriores, santificando o soberano e atribuindo-lhe o poder de Cristo; o basileús ficava, assim, investido da mesma sacralidade e dignidade dos membros do clero.

Felizmente, sobreviveram as descrições das cerimónias de proclamação de alguns imperadores (como Anastácio I, no século v, por Pedro Patrício; ou Justiniano I, no século vi, pelo mesmo autor); e, no seu Livro das Cerimónias, Constantino VII Porfirogeneta (913-959) oferece-nos um relato pormenorizado do protocolo da coroação, provavelmente do século ix e em vigor na época da dinastia macedónica: o papel dos dignitários, as vestes utilizadas, a saída do imperador de uma sala palatina devidamente escoltado, a adoração pelo Senado no Consistório, o cortejo até Santa Sofia, a subida ao ambão (púlpito ou tribuna) com as insígnias da realeza (a clâmide e a coroa), a intervenção do patriarca e do imperador mais velho, o vestir do candidato por um eunuco, a coroação, a aclamação por três vezes ("santo, santo, santo, glória a Deus no alto dos céus e paz na terra"), os votos, a passagem a uma outra sala, o sentar-se no trono móvel, a adoração pelos dignitários e funcionários (com um beijo nos joelhos) e o encerramento da cerimónia por um eunuco (Ravegnani 2008 81). 
Também da coroação de Nicéforo II Focas (em 963) nos chegou uma descrição anónima feita por uma testemunha ocular, que realça o percurso a cavalo pela Mésē, com o candidato vestido com um skaramángion kastórion (uma túnica guarnida de pelo de castor, ou mais provavelmente de cor castanha), que em Santa Sofia trocou pelo tzitzákion (um manto de origem cazar, usado para as coroações durante a semana da Páscoa e na vigília da Epifania). A Miguel Pselo devemos, na Cronografia, uma descrição da coroação de Miguel IV, em 1034, promovida pela amante (a imperatriz Zoé); por aqui se percebe que o Senado teve de obedecer a Zoé, curvando-se perante ela (sentada no trono) e beijando também a mão direita de Miguel IV.

Com o tempo, os ritos de coroação tornaram-se cada vez mais demorados e mais fortemente religiosos. No Tratado sobre os cargos, do Pseudo-Codino, relata-se o caso de Andrónico III Paleólogo (1328-1341) e diz-se que os arcontes (os grandes dignitários) se reuniam no Grande Palácio, passando a noite da véspera em grupo, com familiares, enquanto o povo se juntava na capital; depois da profissão de fé em Santa Sofia, o novo basileús lançava ao povo e aos soldados, no palácio, saquetas de tecido com três moedas de ouro; a seguir, realizava-se a coroação em Santa Sofia (num trono de ouro montado sobre um estrado de madeira, com o candidato vestido com uma túnica) e a unção pelo patriarca, com a imperatriz ao lado, munida de um ramo de palma; seguia-se a bênção, cortejos a cavalo, festas e ainda alguns banquetes, que podiam durar entre 10 e 30 dias (Ravegnani 2008 83-84)!

E já que falamos das imperatrizes, convém explicar que a sua escolha também era objeto de uma regulamentação minuciosa. De um modo geral, predominou o princípio de os basilê̂s casarem com princesas bizantinas (o que, aliás, é próprio do isolacionismo imperial), mas, à medida que as dificuldades se avolumaram, sobretudo a partir dos Paleólogos, a regra conheceu cada vez mais 
exceções: a corte de Constantinopla viu-se constrangida a alianças matrimoniais sucessivas, de forma a facilitar a recolha de apoios à sua sobrevivência; quanto mais avançamos no tempo, menos prestigiosas são essas alianças: primeiro, com casas nobres da Germânia, da França, da Normandia, da Rússia ou da Hungria; depois, com famílias de Montferrato, de Trebizonda, do Peloponeso, de Lesbos ou outras...

Dentro de Bizâncio, não se escolhia uma princesa qualquer; ela até nem precisava de ser rica, mas tinha de pertencer a uma família com boa fama e de reunir certas características físicas. A corte de Constantinopla enviava emissários pelas diversas províncias do império, que se encarregavam de trazer para o palácio candidatas a desposar o novo (e, geralmente, muito jovem) basileús. Ou seja, organizava-se um verdadeiro concurso de beleza, um bride show, durante o qual cerca de uma dúzia de candidatas desfilava perante um júri cortesão, até que uma delas era escolhida como a nova augusta (em grego, sebastế), basílissa ou autokratissa. A já citada Vida de São Filareto conta como Maria da Paflagónia chegou à corte bizantina e foi selecionada pela imperatriz-mãe Irene e pelos altos funcionários palatinos para casar com Constantino VI. $\mathrm{Na}$ sua terra, Maria tinha sido previamente avaliada com o "metro bizantino", com que lhe foram medidos os seios, a estatura e os pés, antes de seguir com a família toda (cerca de 30 pessoas!) para a capital (ed. L. Rydden, 4, pp. 83-93)!

Como o cerimonial da corte não podia funcionar sem uma imperatriz, Miguel II (820-829), quando enviuvou, foi pressionado para casar novamente, tal como Leão VI (886-912) coroou a filha Ana para que os rituais pudessem funcionar normalmente. Alguns imperadores já eram casados quando chegaram ao trono, casos de Justino I (cuja mulher, a antiga escrava Lupicina, mudou o nome para Eufémia) ou de Justiniano (com a antiga atriz Teodora). Em qualquer dos casos, a coroação de uma imperatriz era feita em 
cerimónia à parte; Constantino VII oferece-nos uma descrição deste ritual, numa sala palatina, com a dama escondida por um véu, o patriarca a proferir uma oração e a passar a coroa ao imperador, que depois coroava, ele próprio, a sua esposa como augusta. Era, claro está, um momento alto da vida da corte, embora as imperatrizes raramente tivessem uma influência política real, ficando quase todas circunscritas ao respetivo gineceu; as grandes exceções (embora não as únicas), para além da mulher de Justiniano, foram Irene (por volta do ano 800), Teófane (no terceiro quartel do século x) e as irmãs Zoé e Teodora, no final da dinastia macedónica (meados do século xI).

Em Bizâncio, também não se apreciava o casamento de membros da família imperial com estrangeiros(as), embora tenhamos referido exceções, ditadas por causa urgente: Otão II da Germânia casou com Teófane (provavelmente uma parente do usurpador João Zimisce) e Basílio II deu em casamento a sua irmã Ana ao príncipe Vladimiro de Kiev, a quem ficara a dever o trono.

A chegada de uma imperatriz a Constantinopla era pretexto para mais uma cerimónia solene; tanto Constantino VII como, séculos mais tarde, o Pseudo-Codino nos relatam isso mesmo, referindo a chegada das noivas por mar ou por terra, a sua receção pelas mulheres dos grandes dignitários, a cavalgada até às muralhas da capital, a imposição dos hábitos imperiais e do calçado cor de púrpura, a chegada do cortejo montado ao palácio e outros pormenores. Entre as imperatrizes ocidentais com maior relevo na corte bizantina, devemos mencionar duas: Iolanda-Irene de Montferrato (mulher de Andrónico II Paleólogo, 1282-1328), que ajudou a difundir os costumes feudais, mas que acabou por se retirar para Tessalónica, onde desenvolveu uma política independente de Bizâncio; e Ana de Saboia (mulher de Andrónico III e filha do famoso conde Amadeu V de Saboia), protagonista da maior guerra civil que abalou Bizâncio (em meados do século xiv) 
e famosa também por ter empenhado aos Venezianos as joias da Coroa (pedras preciosas, pérolas e ouro) para conseguir um empréstimo de 30000 ducados a três anos.

As insígnias da realeza bizantina eram ricas e variadas. As mais importantes eram a coroa e o calçado púrpura. A coroa consistia numa banda de tecidos com pedras preciosas e pérolas, colocada sobre a nuca; mas também podia ser de calote rígida (kamelaúkion, típica dos Comnenos) e aberta, com pendentes; numa época tardia, adquiriu uma forma de tampa. Quanto à púrpura, era uma cor reservada ao basileús, sendo produzida, com algumas variações cromáticas, nas fábricas do Estado para o imperador e a sua casa. Só o soberano, sob cujos pés corria o sangue real, podia usar calçado púrpura, afirma Coripo, e, durante o assalto final a Constantinopla pelos Otomanos, em 1453, Constantino XI parece ter-se despido de todas as insígnias imperiais com exceção dos... sapatos púrpura. Procópio explica que este calçado também era próprio do rei da Pérsia e dos sátrapas arménios vassalos de Bizâncio. Era um calçado muito mole e de cor mais intensa do que as rosas sanguíneas (Coripo), e era um sinal tão próprio do basileús que Nicéforo III Botaniate, quando foi deposto (em 1081), pediu para continuar a usá-lo.

Tanto quanto se sabe, na Antiguidade Tardia, os imperadores podiam envergar três tipos de traje:

i) o hábito militar, com couraça, manto de púrpura, lança, escudo, calçado militar, elmo (com diadema e pendentes) e toûpha (a coroa rígida com penas de pavão abertas em leque, para os triunfos);

ii) o hábito consular, com a trabea triumphalis (um manto grande com rosetas em fundo púrpura, enriquecido com gemas), muitas vezes vestido para a celebração de um triunfo e associado (como se vê nos dípticos dos séculos iv 
a vi) a um cetro de marfim agarrado pela mão esquerda e a uma bandeira (máppa) que, brandida pela mão direita, servia para dar início aos jogos no Hipódromo;

iii) o hábito civil, composto por uma túnica branca com banda dourada, um cinto de ouro com gemas, uma clâmide (manto) de púrpura apertada com fíbula com pendentes de ouro e pérolas (a qual fechava sobre o ombro esquerdo, deixando apenas visível o braço direito), calçado púrpura com pedras preciosas e, claro, a coroa.

Com o tempo, o hábito consular caiu em desuso e o hábito civil foi-se tornando cada vez mais complexo e luxuoso, ganhando mais ornamentos preciosos, variando as cores e adquirindo uma pompa especial, pelo menos até à época dos Comnenos (1081-1204). Já no tempo dos Paleólogos, devido às dificuldades financeiras, o vestuário simplificou-se, embora preservando uma grande dignidade e uma fisionomia incomum. As insígnias imperiais eram uma peça nuclear das cerimónias da corte, e a prova disso é que os usurpadores tentavam-se apoderar logo delas, para legitimar a sua posição política. Também os dignitários palatinos utilizavam vestes próprias, que sinalizavam a sua condição e categoria.

A principal fonte para reconstituir a evolução do vestuário imperial bizantino é a iconografia imperial. Neste ponto, é obrigatório salientar os mosaicos da Basílica de São Vital, em Ravenna, que representam de maneira única Justiniano (com o hábito civil) e Teodora, para além de muitos cortesãos e funcionários palatinos. O maior imperador bizantino surge aqui com sandálias púrpuras ornamentadas com pedras preciosas; veste calções de cor púrpura e, sobre estes, uma túnica branca com uma longa faixa de ouro até aos joelhos (dibitísion), apertada na cintura por um cinto vermelho (cingulum); por sobre a túnica, Justiniano 
enverga a clâmide de púrpura roxa com um retângulo ou caixa dourada bordada e decorada com pássaros verdes (tablion); a coroa (stémma) está enriquecida com pendentes de ouro e termina numa pérola encastoada num oval de ouro. No mesmo painel, à direita de Justiniano, vê-se um subdiácono com um turíbulo, o arcebispo de Ravenna (Maximiniano) e diversos dignitários com hábitos de corte (entre os quais, provavelmente, Belisário e Narsés). O imperador segura na mão direita uma patena de ouro (isto é, um prato de bordo largo utilizado para cobrir o cálice e conter a hóstia). Quanto a Teodora, representada noutra zona dos fabulosos mosaicos, avança com um cálice de ouro na mão, com gemas (em homenagem à Igreja); veste uma túnica branca listada de ouro, uma clâmide púrpura com a representação das ofertas dos Reis Magos em baixo e, ao pescoço, traz um colar fino e um colar grosso (maniákēs); a sua coroa é riquíssima, com pendentes longos e uma dupla fila de pérolas.

Os outros símbolos de soberania mais presentes na iconografia imperial são: o globo com a cruz, o cetro, a akakía (um invólucro de seda púrpura contendo pó tumular, em sinal da caducidade humana), o lôros (uma estola ornada de pérolas e pedras preciosas, que cobria o ombro, deixando uma ponta levantada pelo braço esquerdo) e o suppedion (o tapete redondo sobre o qual o basileús poisava os seus pés). Por vezes, são representadas personagens (p. ex., prisioneiros búlgaros, como sucede numa iluminura veneziana de c. 1020 alusiva às conquistas de Basílio II) em atitude de submissão (proskýnēsis). Os grandes funcionários palatinos, eunucos ou barbuti (a começar pelo prōtobestiários, que supervisionava o guarda-roupa imperial), e os principais chefes militares (como o mégas domestikós, de espada ao ombro) também surgem com frequência nesta iconografia, que não raro incluía ainda diversos membros da família imperial e representações de Cristo, da Virgem, de anjos e arcanjos ou de santos. Os mosaicos 
do Mosteiro de Santo Apolinário, em Classe (o porto de Ravenna), merecem igualmente uma referência, devido ao deslumbramento que ainda hoje suscitam.

Curiosamente, em Bizâncio, os cargos não eram hereditários. Quem exercia um cargo público entrava automaticamente para a nobreza, mas havia também muitos títulos isolados (sem ligação com o exercício de atividades públicas) e uma nobreza permanente (tipo nobreza de sangue), com base na tradição e não necessariamente titulada, constituída sobretudo pelos grandes proprietários fundiários, que, a partir dos séculos x e xi, adquiriram uma influência determinante na vida pública bizantina. Como explicámos em nota, os cortesãos estavam divididos em duas categorias: os dignitários da corte, que recebiam uma "dignidade por meio de sinais", honorífica e vitalícia, materializada numa insígnia ou numa patente; e os titulares de cargos temporais, a quem era atribuída uma "dignidade por voz" ou por édito, revogável; em ambos os casos, separavam-se as dignidades dos eunucos das dignidades próprias dos "homens barbudos".

Utilizando como base aquilo que se conhece a partir da época macedónica, em que a hierarquia palatina se sofisticou bastante (misturando antigos cargos tornados dignidades com novos títulos inventados), temos, no que diz respeito às "dignidades por meio de sinais":

A) HOMENS BARBUDOS (18 dignidades, por ordem decrescente): i) cesar (que usava uma coroa sem cruz); ii) nobilissimo (tinha uma túnica púrpura, com ornamentos de ouro); iii) kouropalátēs (ou curo palatii, vestia uma túnica vermelha com ornamento de ouro, clâmide e cinto); iv) zostè patrikía (patrícia "com cintura", a única dignidade feminina da corte, criada por Teófilo para a sogra Teoctista no século ix e assinalada por lâminas 
de marfim) ${ }^{9}$; v) magistro (o antigo magister officiorum, desapareceu nos séculos XI-XII e tinha uma túnica branca tecida em ouro, com dragonas de ouro e cinto de couro vermelho com pedras preciosas); vi) anthýpatos (possuía um codicilo escrito com tinta cor de púrpura); vii) patríkios (lâminas de marfim com codicilo em forma de lei); viii) prōtospatário (o primeiro portador da espada, recebia um colar rígido de ouro com pedras preciosas); ix) disýpatos (duas vezes cônsul, ostentava um diploma); $\mathrm{x}$ ) spatarocandidâtos (tinha um colar de ouro com pérolas); xi) spatário (empunhava uma espada dita chrysókanos, talvez com o punho de ouro); xii) hýpatos (memória do antigo cônsul, possuía um diploma); xiii) strátōr (recebia um chicote de ouro com pedras preciosas); xiv) candidâtos (ostentava um colar com três laços ou nós); xv) mandátōr (exibia um bastão vermelho); xvi) bestítōr (usava um fiblatốrion: um manto fechado por uma fíbula); xvii) silentiários (comunicava por gestos e bater de mãos nas cerimónias, e tinha um bastão de ouro); xviii) stratelátēs epì théma ou apò éparchon (que recebia um diploma em forma de rolo).

B) EUNUCOS (8 dignidades, por ordem decrescente): i) patríkios (que recebia lâminas de patrício com codicilo); ii) prepósitos (recebia a mesma insígnia e desempenhava funções cerimoniais e administrativas); iii) prōtospathários (com colar de ouro ornado de pedras preciosas e pérolas e com as mesmas funções do anterior); iv) primikếrios

\footnotetext{
9 As quatro primeiras dignidades eram um exclusivo da família imperial; com o tempo, o kâ̂sar caiu para terceiro lugar, depois de Aleixo I ter fundado o sebastokrátōr para o irmão e de Manuel Comneno ter criado o despota.
} 
(com as mesmas funções dos dois anteriores, recebia uma túnica branca com dragonas e ornamentos de ouro); v) ostiários (que controlava as portas das salas durante as cerimónias e que tinha como insígnia um bastão de ouro, com o punho ornado de pedras preciosas); vi) spatarokoubikoulários (com funções de guarda da câmara e de escolta, recebia uma espada chrysókanos, talvez com o punho de ouro); vii) koubikoulários (que tinha as mesmas funções do anterior e usava o paragaúdion, uma veste com painéis); viii) nipsistiários (que transportava a bacia para lavar as mãos e envergava uma veste de linho com um bordado acima da cintura).

No que diz respeito às "dignidades por voz", temos:

A) EUNUCOS (9 ou 10 dignidades ou cargos, por ordem decrescente): i) parakoimốmenos do imperador (vigiava o quarto de dormir); ii) prōtobestiários do imperador (supervisionava o guarda-roupa); iii) prepósitos da mesa do imperador; iv) prepósitos da mesa da imperatriz; v) papias (porteiro) do Grande Palácio; vi) deúteros (o vice, ou substituto, do anterior); vii) pinkérnēs (copeiro do imperador); viii) pinkérnēs da imperatriz; ix e x) papías (porteiro) da Magnaura e papías do Palácio de Dafne.

B) HOMENS BARBUDOS (60 dignidades ou cargos): começava pelos mais elevados postos de chefia, cada qual desdobrando-se num ofício mais ou menos amplo e com diversos funcionários administrativos. No topo, estavam o basileopátōr (o tutor do soberano, com plenos poderes administrativos), o reitor (um clérigo com funções imprecisas, mas mais nominais do que reais) e o sýnkellos (o 
eclesiástico que servia de assistente do patriarca nomeado pelo imperador). Depois, vinham os grandes comandos militares: o estratego do tema dos Anatólicos e o domestikós dos scholai, que atingiam os níveis de anthýpatos e de patríkios; a seguir, os restantes cargos militares e civis, até ao $60 .^{\circ}$ posto. Com os Comnenos, foram criados o mégas dux (que comandava no mar e que tinha sob a sua alçada o grande droungários da frota, o almirante, o protokómēs e os condes) e o mégas domestikós (que comandava em terra). Não podendo enunciar aqui estas 60 dignidades, remataremos dizendo que estavam organizadas em sete grupos (mais um grupo à parte, para cargos especiais) e que era aqui que se incluíam o sakkellários (que tratava das finanças do Estado e que ocupava o 32. lugar), o logóteta do génikon (assuntos fiscais), o questor da justiça, o logóteta do stratiōtikón (que cuidava do recrutamento e do abastecimento militares) e até os chefes das fações do Hipódromo (Verdes e Azuis); no final da escala, vinha o domestikós dos imperiais (que era o segundo comandante de uma divisão da guarda).

Note-se, para finalizar, que os eunucos podiam exercer todas as funções públicas dos barbuti, exceto as de éparchos, de questor ou de domestikós. Por esse motivo, a distinção entre uns e outros é mais aparente do que real.

Todo este vasto corpo de dignitários assegurava os sumptuosos cerimoniais da corte bizantina. Entre estes, contavam-se - além dos casos já mencionados - a investidura dos funcionários palatinos (de que Pedro Patrício nos oferece algumas descrições) e a receção aos embaixadores. Esta última cerimónia tinha uma relevância especial (em particular no caso dos embaixadores persas) e, por isso, realizava-se no Consistório, uma sala extra 
destinada a glorificar o imperador; aqui, segundo uma descrição de Coripo, havia um trono em forma de altar, com baldaquino e ornamentado com gemas, quatro colunas, muito ouro maciço, um palco de mármore, degraus de pórfiro e vitórias aladas com coroas de ouro, entre outros requintes. A entrada na sala era controlada por uma tenda: o velum, com três portas de cada lado; o imperador e o seu séquito entravam por um dos lados, que conduzia diretamente ao trono. Quando um visitante era admitido à presença do basileús, os silentiarii afastavam o velum, como numa cerimónia religiosa; competia depois ao embaixador prostrar-se no chão várias vezes, beijar os pés do soberano e mostrar as ofertas que trazia (e que até podiam incluir cavalos); seguia-se a troca de saudações rituais e promessas de descanso e de um novo encontro para tratar dos assuntos comuns; por fim, o embaixador saía tal como tinha entrado, e a sessão encerrava com uma fórmula ritual de tipo religioso e a aclamação do imperador (Ravegnani 2008 129-130).

Também o nascimento de um "porfirogeneta" obedecia a um ritual preciso, que, entre outros números, incluía: uma procissão a Santa Sofia; um espetáculo numa fonte próxima do palácio; uma corrida no Hipódromo (com a proclamação oficial do nome do recém-nascido); a consagração do menino ao Senhor, ao oitavo dia (à entrada da igreja e com pregação e uso de vestuário branco); uma homenagem ao bebé e à mãe, por parte das mulheres e das viúvas dos senadores e dos mais altos dignitários (com ofertas do tipo dos Reis Magos, como explica o Livro das Cerimónias de Constantino VII); e ainda uma festa na capital durante uma semana, com libações e uma bebida aromática (lochózema, o vinho da parturiente). Só depois da instrução religiosa se realizava o batismo em Santa Sofia, com a aplicação da tonsura em cruz (colocando-o acima dos laicos) e com os padrinhos a ficarem como fiéis depositários do cabelinho da criança. 
O dia a dia do basileús era controlado pelos muitos relógios do palácio; começava com o papías (o porteiro) a autorizar a abertura da porta principal e com um dos eunucos a bater três vezes na porta da câmara, para despertar o soberano; a seguir, este vestia-se e rezava no Chrysotríklinos; depois, sentava-se no trono móvel e mandava entrar as pessoas que pretendia receber. No final do despacho, o papias tomava a chave e afastava os presentes, encerrando o palácio. De tarde, repetia-se este ritual.

Os atos solenes realizavam-se nas principais salas do trono e ninguém se podia sentar à mesma altura do imperador. Como já dissemos, o silêncio imperava, com os eunucos a comunicarem entre si através de sinais e de bater de mãos e com o basileús através de gestos. Sentado no trono, o soberano não proferia uma única palavra. Todos estavam sujeitos a adorar o imperador, prostrando-se e beijando-lhe os pés ou os joelhos, exceto ao domingo e no dia de Páscoa; o patriarca era o único que podia limitar-se a saudar o soberano. As mãos deviam estar cruzadas no peito $\mathrm{e}$ a retirada devia acontecer depois de o imperador fazer por três vezes o sinal da cruz para a assembleia; era então que o prepósitos gritava a ordem de saída.

No caso dos cortejos imperiais (a pé ou a cavalo), havia muito mais movimento e alegria; as ruas estavam enfeitadas com flores e plantas odoríferas (hera, louro, murta e alecrim) e os populares exteriorizavam saudações e aclamações, com os chefes das fações do circo a entregarem um libbelárion (contendo súplicas sobre a administração ou sobre as corridas no Hipódromo). Também as cerimónias de celebração de um triunfo eram espetaculares, com cânticos triunfais e a humilhação dos vencidos, à maneira romana; por exemplo, no segundo quartel do século xI, os soldados do general rebelde Jorge Maniakés, cuja cabeça foi exibida no Hipódromo, foram compelidos a montar em asnos virados ao contrário, com o cabelo rapado e com tranças de lixo penduradas ao pescoço, em 
sinal de ignomínia! Miguel Pselo deixou-nos uma bela descrição de um esplêndido triunfo de Miguel IV (o imperador epilético, favorito de Zoé, apesar do seu corpo deformado), a que o autor da Cronografia assistiu presencialmente.

Nos ritos religiosos, o imperador desempenhava um papel ativo, em especial no Natal, na Epifania, na Páscoa, no Pentecostes e na Ressurreição. Nestes períodos, havia procissões solenes a Santa Sofia, dedicação de igrejas, doações de caridade aos pobres e exortações morais aos súbditos numa sala do palácio. Na quinta-feira de Páscoa, o basileús visitava os hospícios de velhos e distribuía fruta ou canela; no domingo seguinte, dava-se o beijo da paz, e os cortesãos beijavam o imperador nos joelhos, nas mãos e na boca. Durante toda a semana pascal, o soberano devia receber no palácio seis recém-batizados e seis órfãos, e entregava dons simbólicos aos dignitários.

O nosso já conhecido Liutprando de Cremona deixou-nos uma descrição fabulosa da sua embaixada de 949 (ao tempo de Constantino VII) a Constantinopla, em representação de Berengário II, marquês de Ivreia e futuro rei de Itália. Sabemos que ele deixou Pavia em 1 de agosto e que viajou com um mercador de Veneza e com um eunuco bizantino que regressava da Hispânia e da Saxónia; chegaram juntos à capital bizantina, a 17 de setembro, e foram requintadamente recebidos na Magnaura:

\footnotetext{
"Diante do cadeiral do imperador havia uma árvore de bronze dourado cujos ramos estavam cheios de pássaros, também eles de bronze dourado, de diversos géneros, que emitiam sons diferentes consoante as diversas espécies. $\mathrm{O}$ assento do imperador fora fabricado de uma tal maneira que, num certo momento, parecia baixo, a seguir mais alto e, de repente, parecia altíssimo. Este cadeiral era guardado, por assim dizer, por dois leões de enorme grandeza, não se
} 
sabe se de bronze ou de madeira, que batiam no chão com a cauda e que, com a boca aberta, movendo a língua, emitiam rugidos. (...) Levado sobre os ombros de dois eunucos, fui conduzido nesta casa à presença do imperador. E se bem que, à minha chegada, os leões rugissem e os pássaros cantassem (...), não fui sacudido por temor algum, por estupor algum, porque tinha sido informado de tudo por aqueles que tinham bom conhecimento disto. Depois de, com o rosto em terra, ter adorado por três vezes o imperador, levantei a cabeça e, subitamente, vi sentado quase ao pé do teto da sala e vestido com outro traje o homem que tinha visto num cadeiral pouco acima do solo! Como é que isto aconteceu, não consegui perceber: talvez o tivessem içado com um cabrestante daqueles com que se içam as árvores das prensas. Diretamente, [o imperador] nunca falou dado que, mesmo que o tivesse feito, a distância teria tornado isto indecoroso; e informou-se por meio do logóteta sobre as condições de vida e de saúde de Berengário. Depois de ter respondido em tom respeitoso, retirei-me a um sinal do intérprete e fui de imediato acolhido no alojamento que me atribuíram" (citado por Ravegnani 2008 139-140).

Algumas das narrativas de Constantino VII confirmam este espantoso relato de Liutprando. O mesmo embaixador participou também num dos célebres banquetes que se realizavam no Triclínio dos XIX Leitos. Estas refeições, e o protocolo rigoroso a que obedeciam, estão especialmente bem descritas no já citado Kletorológion, de Filoteu, redigido em 899 pelo mais famoso mestre de cerimónias de Bizâncio, para orientar os seus sucessores. No triclínio, havia 19 mesas, à volta das quais os convidados se dispunham por ordem de dignidade e precedência, depois de formal e solenemente introduzidos na sala pelo atriklínēs, que 
organizava a cerimónia. Sentavam-se à maneira romana, e a mesa imperial ficava sobrelevada numa abside para o basileús e para doze amigos seus, à maneira de apóstolos; cabiam 228 convidados, pois cada mesa levava uma dúzia de pessoas. No Natal e na Epifania, havia doze banquetes consecutivos, e as doze personagens que faziam companhia ao basileús na sua mesa eram: dois magistri, seis anthýpatoi, patrícios e estrategos, dois amigos búlgaros e dois funcionários da categoria de logóteta do stratiōtikón ou inferior; os outros 168 convidados incluíam os senadores e os dignitários palatinos, claro está, e também 24 agarēnoí do Pretório, 12 homens dos amigos búlgaros e 12 irmãos pobres (um sinal da generosidade do soberano cristão). Os bokálioi (arautos ou cantores) davam a ordem para os convidados se estenderem nos leitos e, de vez em quando, o banquete era interrompido por música e por aclamações ao imperador, com as clâmides despidas, ou então por jogos ou pelo envio de algum alimento especial a partir da mesa de honra, através do kastrésios (o funcionário eunuco adstrito à mesa do soberano).

Liutprando faz referência expressa a estas tradições e salienta os manjares variados e deliciosos, o vasilhame de ouro, os espetáculos acrobáticos, os carros de fruta elevados com um cabrestante mecânico preso ao teto e vários outros aspetos de uma refeição inolvidável (Ravegnani 2008 145-147). Como seria de esperar, com a decadência do império e o esgotamento do Tesouro bizantino, o fausto prandial diminuiu bastante, tal como as procissões e outros cortejos e cerimoniais...

Ainda assim, manteve-se a paixão dos imperadores por alguns desportos; para além do tzykánion (já referido e que Teodósio II terá introduzido no século v) e do jogo da bola (que Alexandre apreciava tanto que deu a vida por ele, após uma partida jogada sob um sol inclemente), deve notar-se que existia um hipódromo no próprio palácio, e ainda outros na periferia; Miguel III 
frequentava-os muito, envergando a casaca dos Azuis. No entanto, a maior paixão desportiva dos basileîs era a caça, realizada em grandes coutadas que existiam nos seus próprios palácios, ou então em florestas verdadeiras, na Ásia Menor; já vimos que alguns imperadores morreram durante uma caçada, como foi o caso de João II Comneno, ou o de Basílio I, que, apesar da sua força hercúlea, encontrou a morte quando andava a perseguir os cervos. Bem ligeira deve ter sido a vida de Romano II Porfirogeneta (959-963), um soberano muito pouco dado às agruras da governação e que dividia assim o seu tempo: de manhã, presidia às corridas no Hipódromo, findas as quais almoçava com os senadores e jogava no Tzykanistérion; de tarde, atravessava o Bósforo para ir caçar, regressando ao palácio depois de matar quatro javalis; morreu bastante novo, mas aproveitou bem o tempo que teve...

Já outros imperadores eram mais dados ao mecenato cultural, como sucedeu com Teodósio II, com Justiniano I, com Maurício, com Constantino V, com Leão VI, com Constantino VII, com Nicéforo II Focas, com Constantino X e, por fim, com Miguel VII Ducas; a todos eles se devem, direta ou indiretamente, obras literárias, filosóficas ou técnicas relevantes; por sua vez, os Comnenos, eram sobretudo homens de guerra. Durante o exílio em Niceia e após a restauração bizantina de 1261, a cultura voltou a ter alguns momentos altos, sobretudo com Teodoro II Lascaris e com João VI Cantacuzeno. Outros basileîs, enfim, preferiam entregar-se a devoções religiosas ou, em contraponto, a ocupações mais frívolas, como foi o caso dos sibaritas Miguel III, Constantino VIII ou Constantino IX Monómaco...

Infelizmente, entre uns e outros, muitos acabaram mal, sendo porventura o suplício de Andrónico I Comneno (1183-1185), que mandara matar a imperatriz-mãe e o herdeiro legítimo do trono, o mais cruel de todos. Capturado em fuga na costa sul do mar Negro, foi horrivelmente executado por Isaac II Anjo: cortaram-lhe a mão 
direita, foi encerrado num cárcere sem comida nem água, teve um olho escavado, viu-se obrigado a desfilar vergonhosamente pela capital amarrado a um camelo ou a um asno lazarento (sujeito aos impropérios, aos golpes e ao lançamento de dejetos por parte da populaça) e, por fim, foi amarrado a duas colunas no Hipódromo, com mutilação genital e outras sevícias, até expirar.

O leitor dirá, desse modo respondendo à pergunta com que abrimos este capítulo, se o deslumbramento cerimonial bizantino e o fascínio do poder num dos mais duradouros impérios da história europeia compensaria o risco de ascender um dia a basileús dei Romani...

\section{Bibliografia}

\section{Fontes}

Conca, F. (1996), Procopio. Storie Segrete. Tradução italiana de Paolo Cesaretti. Edição bilingue. Milão, BUR Rizzoli.

Dennis, G. T. (1984), Maurice's Strategikon. Handbook of Byzantine Military Strategy. Philadelphia, University of Pennsylvania Press.

Dennis, G. T. (1985), Three Byzantine Military Treatises. Washington DC, Dumbarton Oaks.

Dennis, G. T. (2014), The Taktika of Leo VI. Revised edition. Washington D. C., Dumbarton Oaks Texts.

Frankopan, P. (2009), Anna Komnene, The Alexiad. Tradução de E. R. A. Sewter. Nova Iorque, Penguin.

Leib, B. (1937-1945), Anne Comnène, Alexíade, 3 vols. Paris.

Panascìa, M. (1993), Constantino Porfirogenito, Ibn Rosteb e Liutprando da Cremona, Il libro delle cerimonie. Trad. italiana parcial. Palermo.

Rydén, L. (2002), Niketas, The Life of St Philaretos, the Merciful, written by bis grandson Niketas. A Critical Edition, with Introduction, Translation, Notes, and Indices. Uppsala, Swedish Research Council. 
Signes, Juan (2005), Miguel Psellos, Vidas de los emperadores de Bizancio. Trad. espanhola, Madrid, Gredos.

Tolentino de Mendonça, J. (2006), Bíblia Ilustrada, vol. V. Tradução de João Ferreira Annes d'Almeida. Lisboa, Círculo de Leitores.

\section{Estudos Citados}

Azzara, C. (2013), Teodorico. Bolonha, Il Mulino.

Cesaretti, P. (2003), Teodora. Ascesa di un'imperatrice. Milão, Mondadori.

Cheynet, J.-C., Byzance. L'Empire Romain d'Orient. Paris, Armand Colin.

Delumeau, J.-P. / Heullant-Donat, I. (2000), L'Italie au Moyen Âge, $V^{\circledR}-X V^{e}$ siècle. Paris, Hachette.

Fédou, R. et alii ( $\left.{ }^{3} 1995\right)$, Lexique historique du Moyen Âge. Paris, Armand Colin. Haldon, J. (2001), The Byzantine Wars. Battles and Campaigns of the Byzantine Era. Charleston, Tempus Publishing.

Kaplan, M. (1991), Tout l'or de Byzance. Paris, Gallimard.

Luttwak, E. (2009), The Grand Strategy of the Byzantine Empire. Harvard College. Meier, M. (2007), Giustiniano. Trad. italiana, Bolonha, Il Mulino.

Monteiro, J. G. (2006), Lições de História da Idade Média (séculos XI-XV). Coimbra, Faculdade de Letras.

Norwich, J. J. (2012), Os Papas: A História. Trad. portuguesa, Lisboa, Civilização. Ostrogorsky, G. ( ${ }^{31963), ~ G e s c h i c h t e ~ d e s ~ b y z a n t i n i s c h e n ~ S t a a t e s . ~ M u n i q u e, ~ C . ~ H . ~ B e c k . ~}$ Ravegnani, G. (2006), Introduzione alla storia bizantina. Bolonha, Il Mulino. Ravegnani, G. (2008), Imperatori di Bisanzio. Bolonha, Il Mulino.

\section{Cronologia Breve}

451: Concílio de Calcedónia.

527-565: principado de Justiniano I.

532: Sedição Níka. 
537: Reconstrução da Igreja de Santa Sofia, sob a direção dos arquitetos Antémio de Trales e Isidoro de Mileto.

547: Construção da Basílica de São Vital de Ravenna (com os célebres mosaicos de Justiniano e Teodora).

610-711: dinastia heracliana.

636: batalha do rio Yarmouk (vitória dos Árabes e tomada da Palestina e da Síria).

726: Édito de Leão III contra a veneração das imagens (início da questão iconoclasta).

751: tomada de Ravenna pelos Lombardos e queda do exarcado bizantino em Itália.

843: Restauração do culto das imagens e fim do iconoclasmo. 867-1056: dinastia macedónica.

963-1025: principado de Basílio II (com grandes vitórias militares, nomeadamente contra os Búlgaros).

1071: Batalha de Manzikert (derrota bizantina pelos Turcos). 1081-1185: dinastia dos Comnenos.

1176: Batalha de Miriocéfalo (derrota bizantina às mãos dos Turcos Seljúcidas).

1204: Conquista de Constantinopla pela IV Cruzada. Início do "Império de Niceia".

1261: Restauração bizantina, com a reconquista de Constantinopla por Miguel VIII (início da dinastia dos Paleólogos).

1396: derrota da cruzada cristã em Nicópolis.

1443-1444: Cruzada de Varna, liderada pelo rei da Hungria (Ladislau III) e derrotada pelo sultão otomano, Murad II.

1453: Conquista de Constantinopla pelos Turcos Otomanos (Mehmet II). Morte do último imperador bizantino (Constantino XI Paleólogo). 
FIGURAS 
(Página deixada propositadamente em branco). 


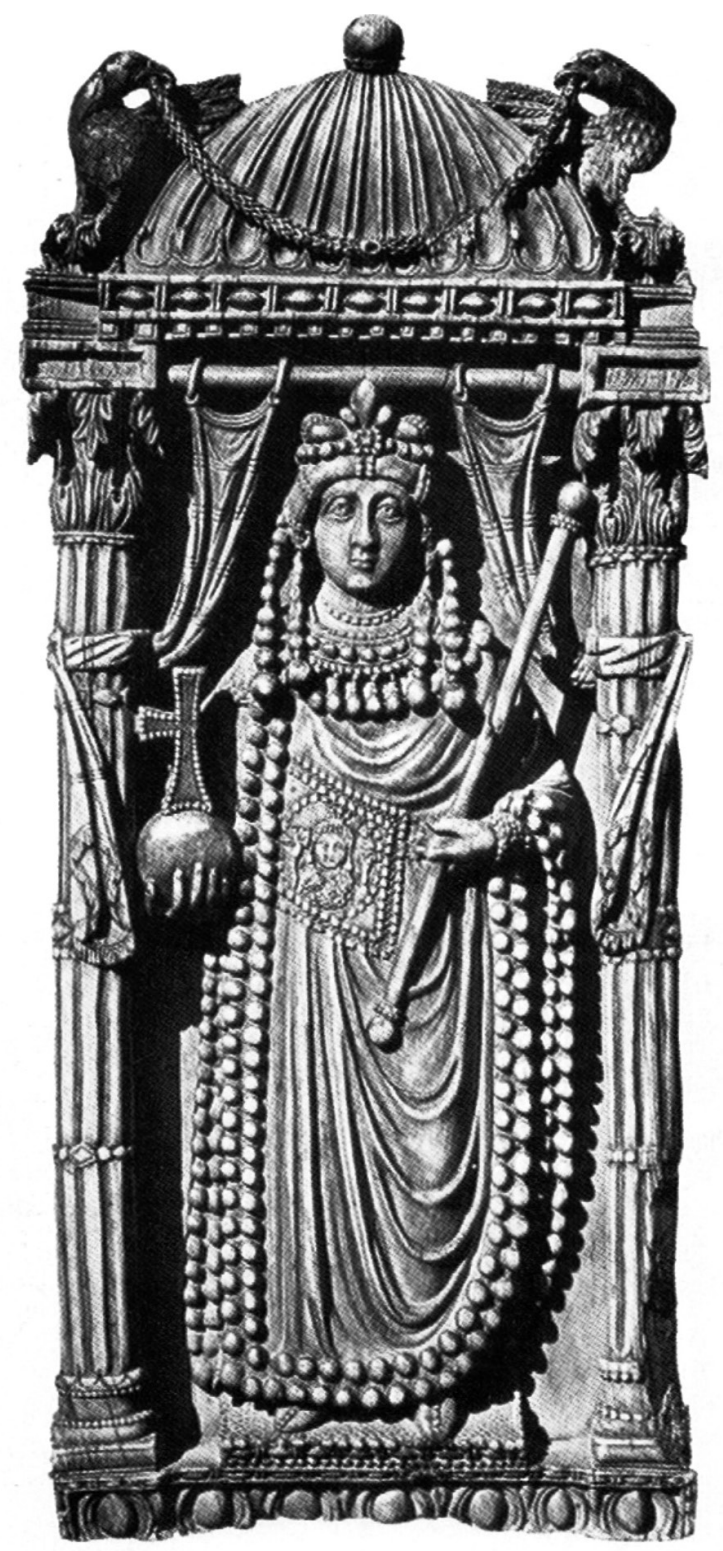

Imperatriz anónima (provavelmente Ariadne). Marfim, tábua de díptico imperial de fins do séc. V - inícios do séc. VI. Florença, Museo Nazionale del Bargello. 


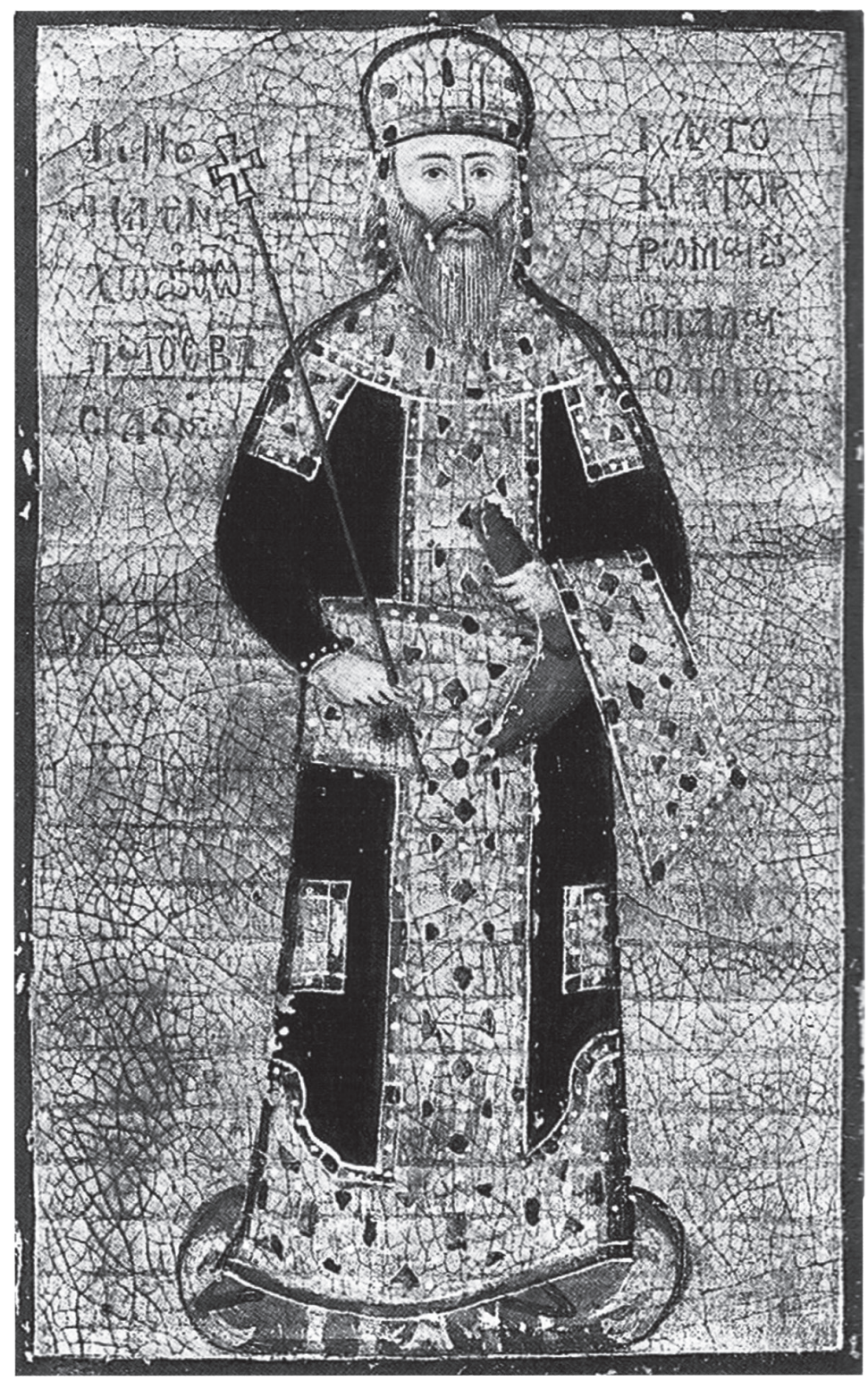

Manuel II Paleólogo.

Iluminura do séc. XV (c. 1407). Paris, Bibliothéque

Nationale, cod. Paris. Suppl. gr. 309, fl. VIr.

Giorgio Ravegnani, Imperatori di Bisanzio, Bolonha, 2008, gravura 14 


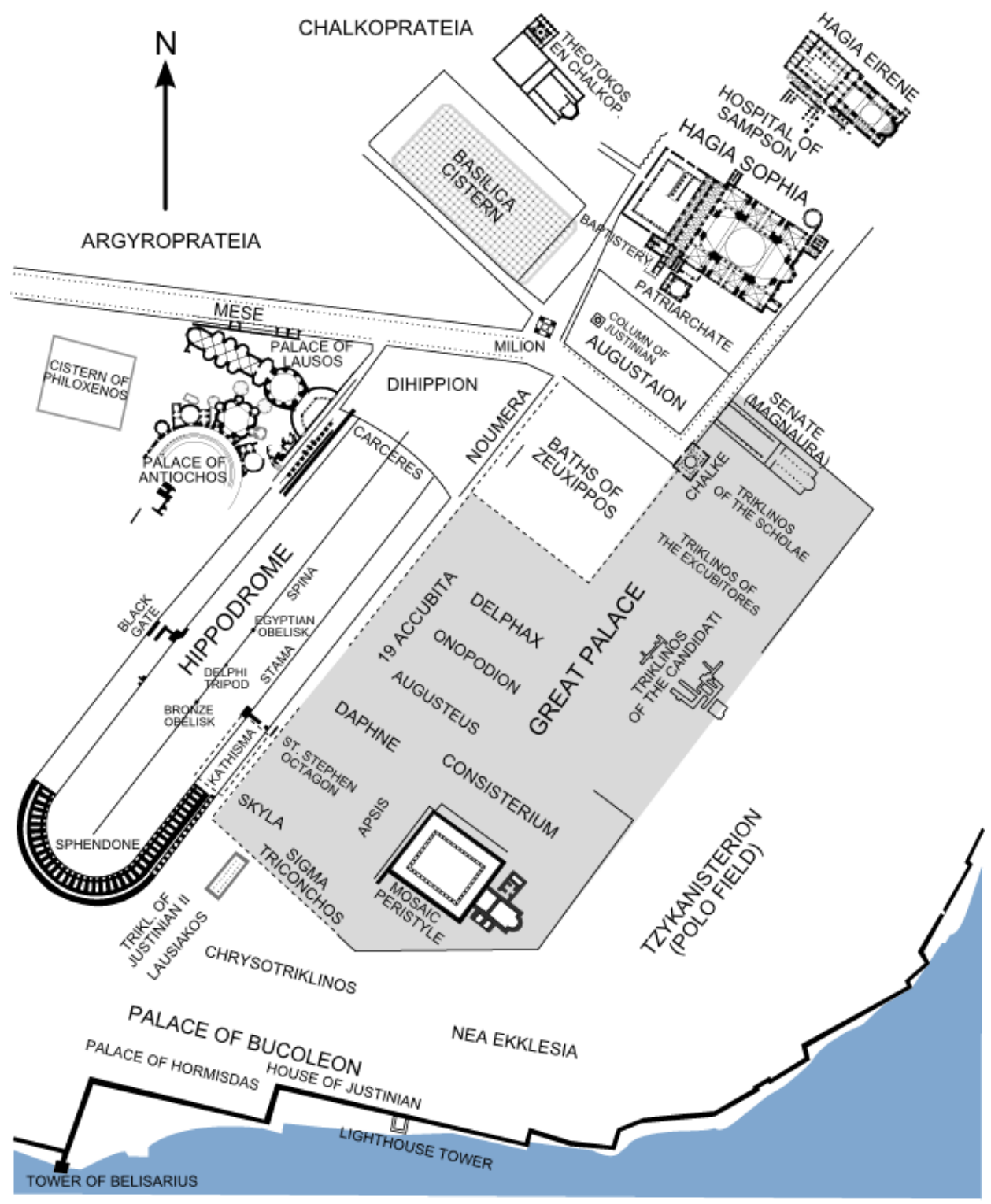

O Grande Palácio de Constantinopla (Magnum Palatium)

Fonte: https://pt.wikipedia.org/wiki/Grande_Palácio_de_Constantinopla 


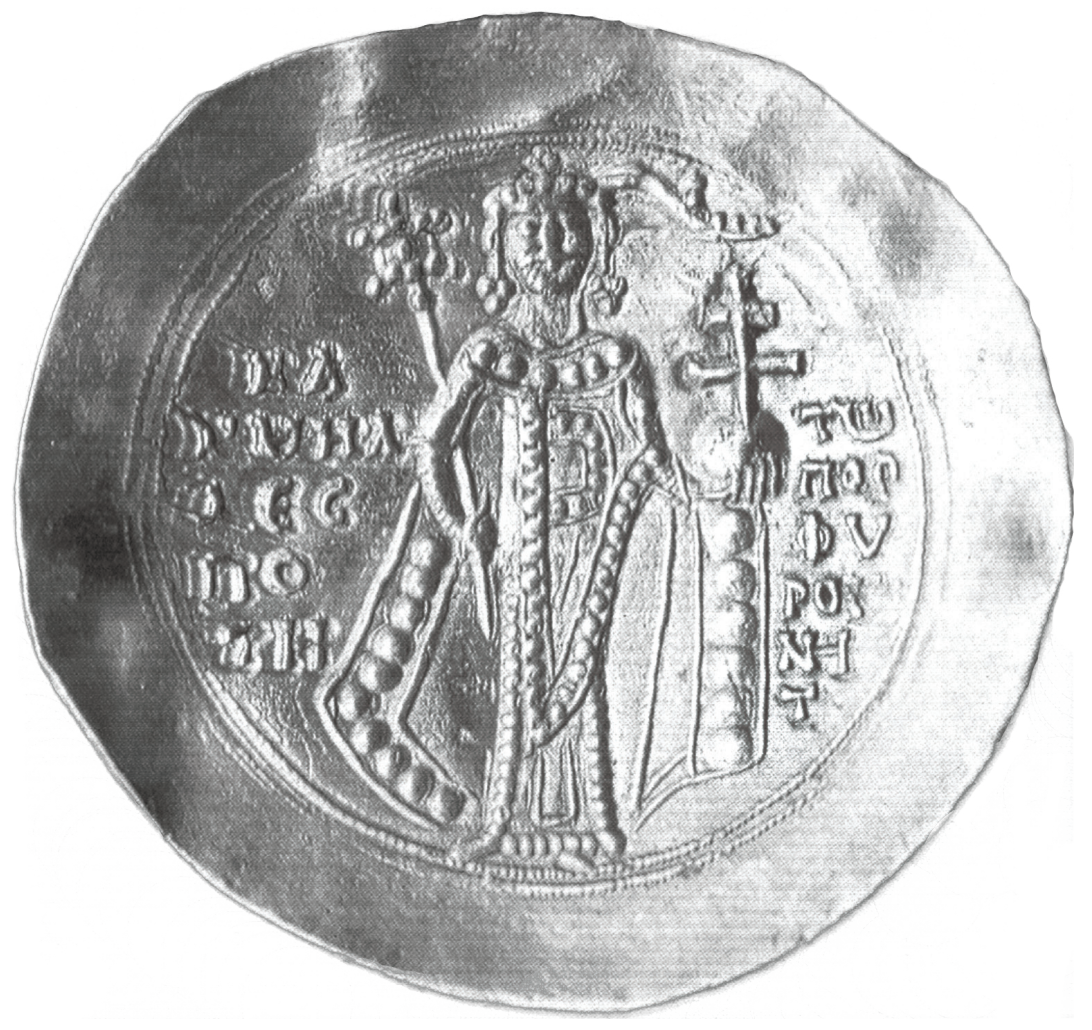

Moeda de ouro do imperador Manuel I (1143-1180)

John Haldon, The Byzantine Wars, Stroud, 2001, gravura 6 